\title{
Senegal: Staff Report for the 2008 Article IV Consultation, First Review Under the Policy Support Instrument, and Request for Waiver of Assessment Criterion and Modification of Assessment Criteria-Staff Report; Staff Supplement; Staff Statement; Public Information Notice and Press Release on the Executive Board Discussion; and Statement by the Executive Director for Senegal
}

Under Article IV of the IMF's Articles of Agreement, the IMF holds bilateral discussions with members, usually every year. In the context of a combined discussion of the 2008 Article IV consultation with Senegal, first review under the Policy Support Instrument, and request for waiver of assessment criterion and modification of assessment criteria, the following documents have been released and are included in this package:

- $\quad$ The staff report for the 2008 Article IV Consultation, First Review Under the Policy Support Instrument, and Request for Waiver of Assessment Criterion and Modification of Assessment Criteria, prepared by a staff team of the IMF, following discussions that ended on April 14, 2008, with officials of Senegal on economic developments and policies. Based on information available at the time of these discussions, the staff report was completed on May 30, 2008. The views expressed in the staff report are those of the staff team and do not necessarily reflect the views of the Executive Board of the IMF.

- $\quad$ A staff supplement on the joint IMF/World Bank debt sustainability analysis.

- A staff statement of June 18, 2008 updating information on recent developments.

- $\quad$ A public information notice (PIN) and Press Release summarizing the views of the Executive Board as expressed during its June 18, 2008 discussion of the staff report that concluded the Article IV consultation and completed the review and request.

- $\quad$ A statement by the Executive Director for Senegal.

The documents listed below have been or will be separately released.

Letter of Intent sent to the IMF by the authorities of Senegal*

Memorandum of Economic and Financial Policies by the authorities of Senegal*

Technical Memorandum of Understanding*

Selected Issues Paper

*Also included in the Staff Report

The policy of publication of staff reports and other documents allows for the deletion of market-sensitive information.

To assist the IMF in evaluating the publication policy, reader comments are invited and may be sent by e-mail to publicationpolicy@imf.org.

$$
\begin{aligned}
& \text { Copies of this report are available to the public from } \\
& \text { International Monetary Fund • Publication Services } \\
& 70019^{\text {th }} \text { Street, N.W. • Washington, D.C. 20431 } \\
& \text { Telephone: (202) 623-7430 • Telefax: (202) 623-7201 } \\
& \text { E-mail: publications@imf.org • Internet: http://www.imf.org }
\end{aligned}
$$

Price: $\$ 18.00$ a copy

\section{International Monetary Fund Washington, D.C.}



INTERNATIONAL MONETARY FUND

SENEGAL

\title{
Staff Report for the 2008 Article IV Consultation, First Review Under the Policy Support Instrument, and Request for Waiver of Assessment Criterion and Modification of Assessment Criteria
}

\author{
Prepared by the African Department \\ (In consultation with other departments) \\ Approved by Sharmini Coorey and Adnan Mazarei
}

May 30, 2008

Discussions. March 26-April 9, 2008 in Dakar and April 13-14, 2008 in Washington. Staff met with Prime Minister Soumaré, Minister of Economy and Finance Diop, Minister of Budget Sar, other ministers, BCEAO National Director Sene, and other government officials, as well as representatives of the private sector, commercial banks, NGOs, and Senegal's development partners. The staff team comprised Messrs. Mueller (head), Lakwijk, Roudet (all AFR), Ms. Adenauer (FAD), and Ms. Mitra (PDR). The team was assisted by Mr. Segura-Ubiergo, the Fund's resident representative, and his staff.

Policy Support Instrument (PSI). The three-year PSI was approved on November 2, 2007. The report recommends completion of the first program review.

Article IV consultations. The discussions focused on (i) obstacles to raising economic growth and reducing poverty and the authorities' multi-pronged strategy to put in place a new growth model; (ii) external competitiveness; and (iii) the sustainability of fiscal policy in the face of various fiscal risks.

Selected Issues Paper. The three chapters address: (i) the real effective exchange rate (REER) and competitiveness; (ii) policy options for dealing with food and energy price increases; and (iii) the budgetary implications of an Economic Partnership Agreement with the EU. 


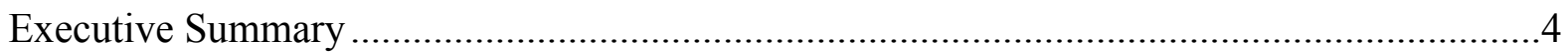

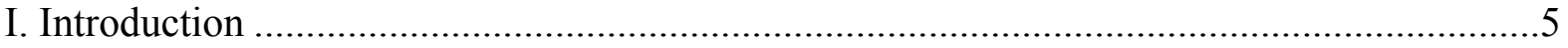

II. Higher Economic Growth But Worrisome Surge in Food and Energy Prices ....................5

III. The PSI-An Overall Good Program Start But Some Fiscal Slippages ..........................

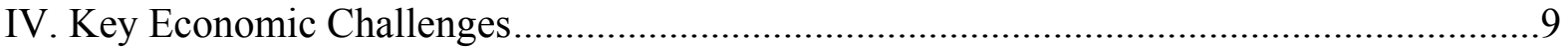

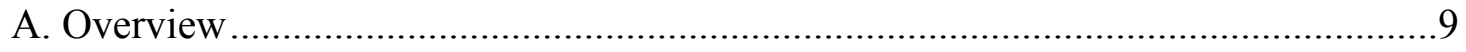

B. Growth, Poverty, and Competitiveness ............................................................ 10

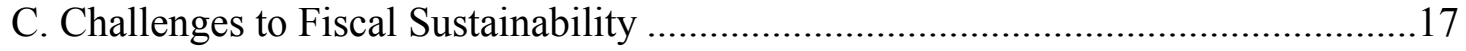

D. Macroeconomic Framework and Risks...........................................................19

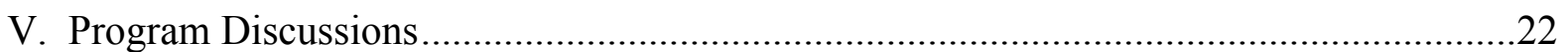

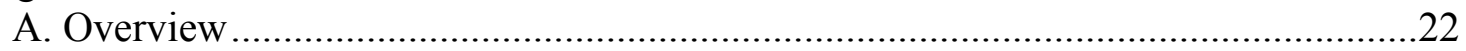

B. Fiscal Policy ...............................................................................................22

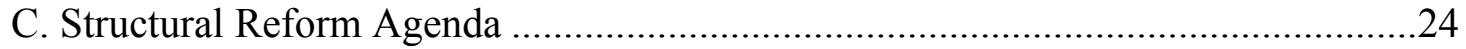

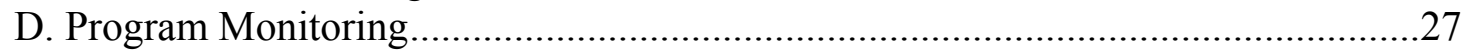

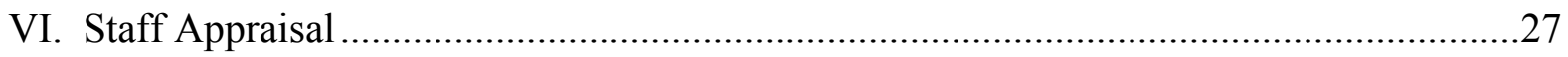

Boxes

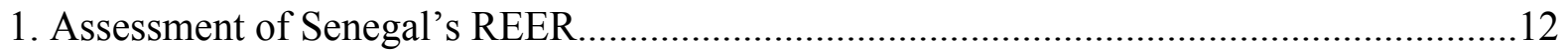

2. Structural Impediments to Higher Competitiveness .....................................................13

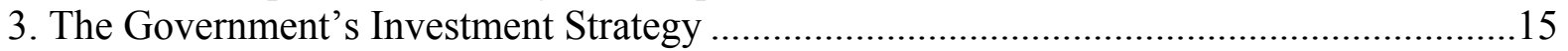

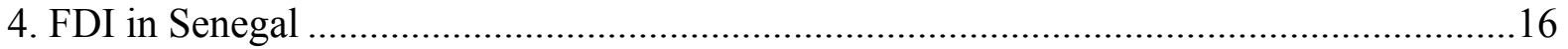

5. Rising Food and Energy Prices: Policy Options........................................................ 18

6. The Budgetary Impact of an Economic Partnership Agreement .......................................19

7. The Dakar Integrated Special Economic Zone (DISEZ) ...............................................25

Figures

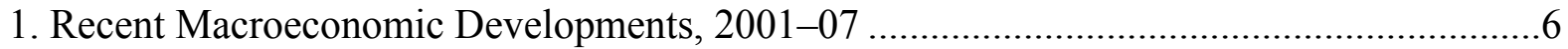

2. Millennium Development Goals, 1990-2015 ............................................................. 11

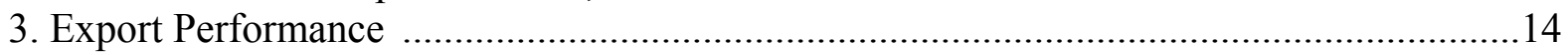

4. Medium-Term Outlook, 2006-12 …........................................................................2 21

Tables

1. Selected Economic and Financial Indicators, 2004-13 ............................................29

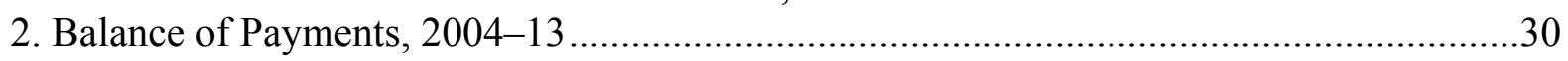

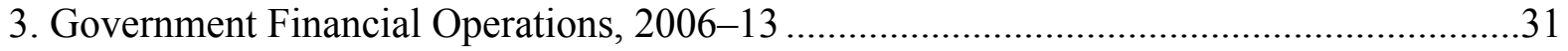

4. Government Financial Operations, 2006-13 (in percent of GDP) ..................................32

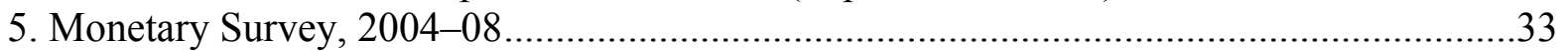




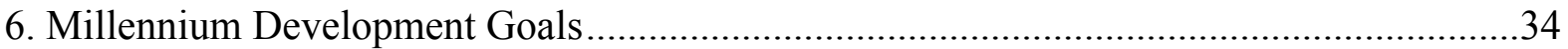

7. Financial Soundness Indicators for the Banking Sector, 2002-07 .................................35

8. Quantitative Assessment Criteria and Indicative Targets, 2007-08 .................................36

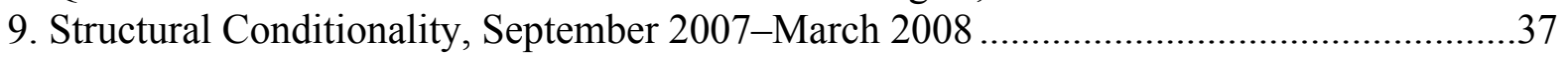

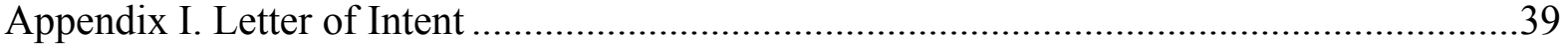

Attachment I. Memorandum of Economic and Financial Policies ..................................41

Attachment II. Technical Memorandum of Understanding .............................................51 


\section{Executive Summary}

Senegal's macroeconomic performance improved in 2007, broadly in line with program projections. While economic growth recovered, rapidly rising food and energy prices raised inflation and put pressure on the fiscal and external accounts.

Although the headline overall fiscal deficit declined and the program target on the basic fiscal balance was met, there were fiscal slippages in 2007. The authorities committed more spending than the program envisaged, partly for food and energy subsidies, and postponed to 2008 the issuance of payment orders equivalent to 2 percent of GDP, delaying payments to the private sector. In addition, there is a possibility that extrabudgetary spending of about 0.2 percent of GDP may have occurred.

Aside from this fiscal issue, Senegal performed well under the PSI. All structural conditionality was respected (albeit one measure only partially), and all quantitative assessment criteria were met except the zero ceiling on domestic arrears, which was exceeded for the first three weeks after the program began. Because corrective action was prompt, the staff supports the authorities' request for a waiver.

Senegal's economic outlook remains positive, although downside risks have increased. Economic growth could accelerate slightly and the external current account deficit stabilize, with its financing being increasingly provided by FDI. Inflation should return to its historic average once price pressures on food and energy products abate.

The authorities agreed with the staff's analysis that structural reforms will be key to raising external competitiveness and helping turn around Senegal's long-standing poor export performance. The real exchange rate seems to be in line with economic fundamentals.

The PSI's fiscal program aims to correct past fiscal slippages, preserve debt sustainability, contribute to domestic stability, and restore the integrity of the budget framework. The authorities need to revisit their system of food and energy subsidies to bring it in line with budgetary affordability, improve its targeting, and limit economic distortions. The program's structural measures will focus on fiscal governance and transparency and help shore up fiscal policy against a variety of risks, including from the planned special economic zone.

On balance, the staff recommends completion of the first PSI program review. 


\section{INTRODUCTION}

1. Senegal faces important macroeconomic challenges which it has begun to address under an economic program supported by the three-year PSI approved in November 2007. These challenges were identified during the 2006 Article IV consultation discussions and became the pillars of the PSI: (i) reversing the rising trend in the fiscal deficit to underpin macroeconomic stability and safeguard debt sustainability; (ii) improving fiscal governance and transparency so as to enhance policy credibility and sustain external assistance; (iii) encouraging private sector activity by improving the business environment and addressing structural impediments to higher economic growth; and (iv) limiting financial sector vulnerabilities and raising the sector's contribution to the economy.

2. The PSI is off to a broadly satisfactory start but new challenges have emerged. It enjoys strong political support and has served its intended role of providing a framework for economic policymaking and reassuring donors. However, the international environment has become more challenging in recent months, including through the more subdued world growth outlook, the turbulence in financial markets, and, in particular, the sharp rise in food and energy prices. The latter has triggered street demonstrations and forced the government to adopt countervailing measures. These measures, together with investment spending pressures and problems controlling spending near year-end, significantly affected budget execution in 2007 and limit the government's room for maneuver going forward.

\section{Higher Economic Growth But Worrisome Surge in FoOd AND EnERgy PriceS}

3. The Senegalese economy rebounded in 2007 , broadly in line with the projections underlying the program (Figure 1).

- Economic growth. Buoyant activity in the services and construction sectors raised GDP growth to $4 \frac{3}{4} 4$ percent in 2007, from 21/4 percent in 2006 (Table 1). However, for the second year in a row, agricultural output declined.

- Inflation. Rapidly rising energy and food prices raised inflation and put pressure on the external and fiscal accounts. Inflation reached 6 percent, the highest level since the 1994 devaluation. The authorities suspended VAT and customs duties on certain food products in mid-2007, gradually raised the subsidy on butane gas, and introduced subsidies on petroleum products in late 2007. This may have temporarily restrained inflation and helped maintain social peace, but the budgetary costs were substantial, at $1 \frac{1 / 2}{2}$ percent of GDP.

- $\quad$ Balance of payments and external debt. The increase in the external current account deficit to $10 \frac{1}{2}$ percent of GDP reflected rising energy and food imports, while exports remained stagnant on account of the delayed restructuring of the phosphate 
Figure 1. Senegal: Recent Macroeconomic Developments, 2001-07

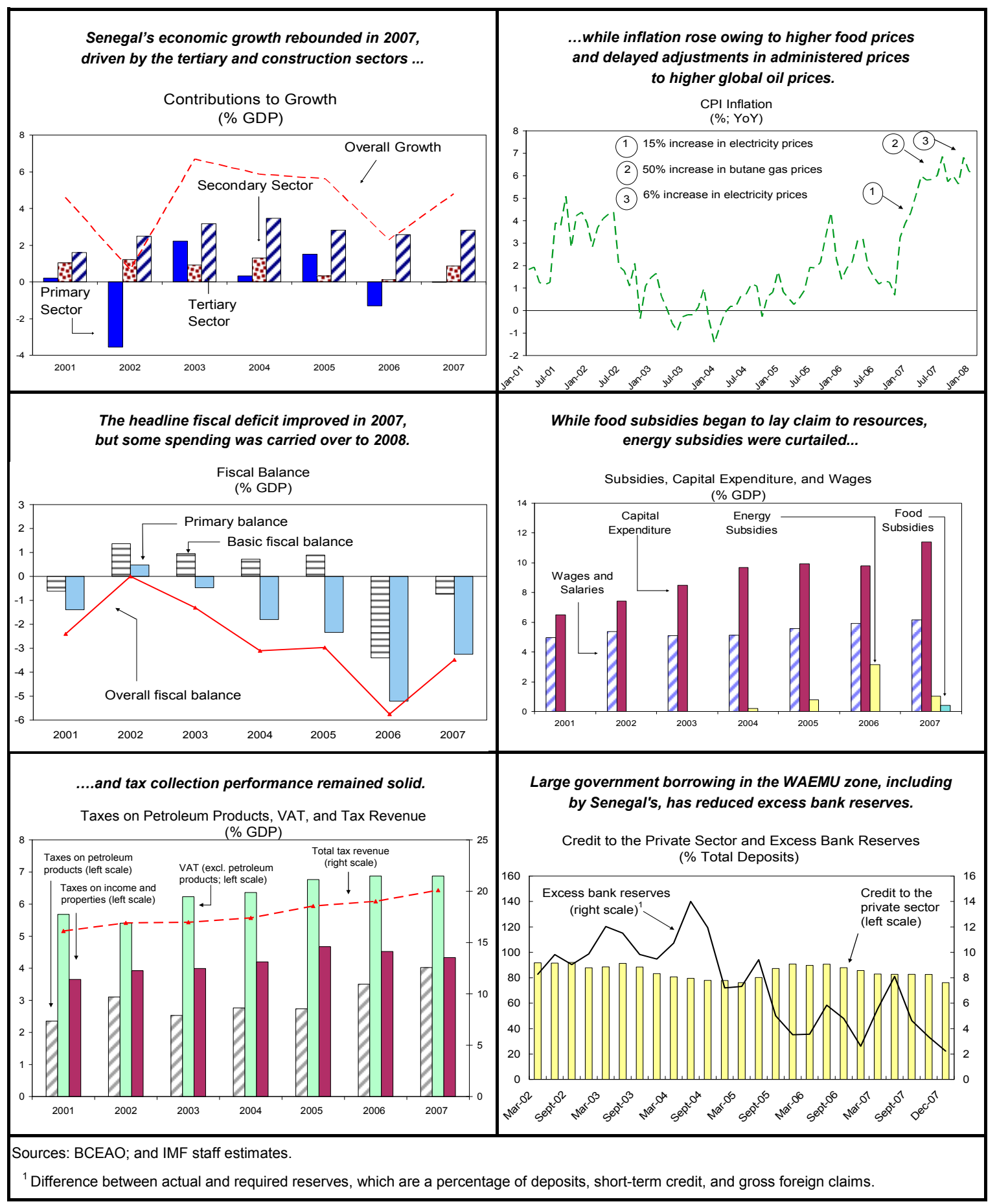


company ICS (Table 2). ${ }^{1}$ Capital inflows increased due to higher foreign direct investment (FDI) and receipts from the sale of a third telecom license, which helped keep external debt indicators stable relative to 2006 .

- $\quad$ Fiscal policy. The headline overall fiscal deficit, defined on a payment order basis, was kept at 31/2 percent of GDP in 2007, compared with 6 percent of GDP a year before (Tables 3 and 4). However, unsettled expenditure commitments equivalent to 2 percent of GDP need to be carried over to 2008, causing significant delays in payments to the private sector (see below). This suggests that the overall fiscal deficit in 2007 on a commitment basis was about 5 $1 \frac{1}{2}$ percent of GDP; since most of the goods and services were delivered in 2007, this may have contributed to upward pressure on prices in certain areas, such as construction.

- $\quad$ Financial sector. While micro finance has experienced strong growth, bank credit to the economy has been stagnant over the past three years, at about 23 percent of GDP. Although banks are profitable and generally well capitalized, they suffer from sizeable nonperforming loans, mainly as a result of the financial difficulties of ICS and energy sector companies in a context of excessive loan concentration (Table 7). ${ }^{2}$

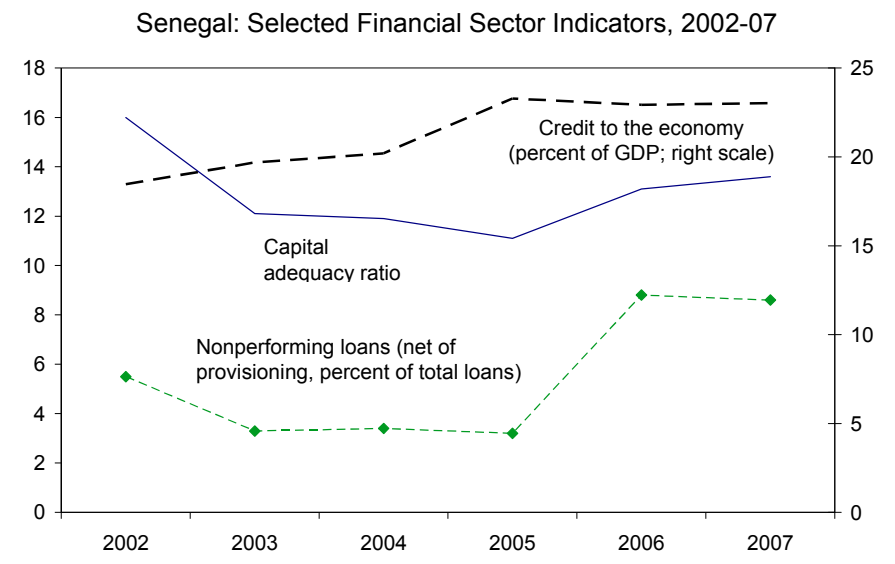

\footnotetext{
${ }^{1}$ ICS is Senegal's largest company, but its output in 2007 was at one-third of 2005 capacity because negotiations on its rehabilitation have been protracted (see Box 2 in IMF Country Report No. 07/358). In March 2008, a local court accepted the restructuring plan agreed between the foreign majority owner and the government. This decision allowed the government to rescind its bank loan guarantee. Output is projected to reach capacity by 2010 .

${ }^{2}$ WAEMU regulations require that ICS claims continue to be classified as nonperforming, but provisions will have to be raised only if ICS has difficulties in servicing its rescheduled debt.
} 


\section{The PSI-An Overall Good Program Start But Some Fiscal Slippages}

4. The program has started well on the structural side (Table 9). The authorities respected all structural conditions, although one was met partially.

- $\quad$ Fiscal governance and transparency. The authorities expanded the SIGFIP software to improve the monitoring of arrears and other payment delays; modified the legal status of the agency (APIX) in charge of the new Dakar Integrated Special Economic Zone (DISEZ); implemented a new public procurement framework; and completed a study on the revenue implications of DISEZ (see Box 7 below). The 2004 and 2005 Treasury accounts have been partially submitted to the audit court, and the submission is expected to be completed soon.

- $\quad$ Private sector development. The authorities adopted a framework law and decree for the Accelerated Growth Strategy, setting the stage for its implementation; and issued a decree to facilitate short-term employment contracts in an effort to increase labor market flexibility.

- $\quad$ Financial sector development. The authorities submitted to Parliament the new microfinance law that will strengthen supervision of this rapidly growing sector; ${ }^{3}$ and completed the study to improve accounting practices, which the 2001 and 2004 FSAPs identified as a key obstacle to financial intermediation. ${ }^{4}$

\section{Other structural measures in the October 2007 MEFP that were not subject to} conditionality have also been put in place. Notably, the authorities followed through on their commitments on the airport project and the DISEZ contract, which should limit fiscal risks.

6. The authorities met most end-2007 quantitative targets (Table 8). The continuous quantitative assessment criterion on domestic arrears was not respected for a three-week period immediately after the PSI was approved. The authorities quickly eliminated all such arrears by end-November when they became aware of the nonobservance, and request a waiver. In the staff's view, the quick corrective action taken and the nonrecurrence of arrears since then form a good basis for supporting the waiver. The indicative ceiling on the share of single-tender public contracts was slightly exceeded in the last quarter of 2007, although single tenders declined substantially from earlier in the year. ${ }^{5}$

\footnotetext{
${ }^{3}$ Microfinance accounts for one-tenth of private sector credit.

${ }^{4}$ Some 80 percent of loan applications are currently rejected by banks, with difficulties in securing and enforcing collateral and low accounting quality being cited as main reasons.

${ }^{5}$ The share of single tenders surged again in early 2008, as ministries and agencies took advantage of the complementary period to issue such tenders related to lines in the 2007 budget.
} 
7. While the basic fiscal balance target was met, the surge in unsettled expenditure commitments raises concerns. ${ }^{6}$ The authorities committed more capital and current spending than envisaged under the program and warranted in light of Senegal's macroeconomic circumstances and financing constraints. In addition, they did not react through compensating expenditure cuts to the accelerating costs of food and energy subsidies. This necessitated an abrupt slowdown in the issuance of payment orders toward year-end, with a concomitant rise in payment delays to the private sector. ${ }^{7}$ There also is a possibility that extrabudgetary spending may have occurred in 2007. The authorities agreed to corrective actions for the first program review, as discussed below.

\section{Key ECONOMic Challenges}

\section{A. Overview}

\section{The 2008 Article IV discussions devoted particular attention to a range of} longer-term and some more immediate economic issues. ${ }^{8}$ The emerging conclusions also informed the selection of conditionality for the PSI program review.

- Obstacles to raising economic growth and reducing poverty and the authorities' multi-pronged strategy to put in place a new approach to growth were discussed from a longer-term perspective. In this context, Senegal's external competitiveness in light of the continued sluggishness of exports was assessed, with a view to identifying appropriate policy options.

- $\quad$ From a more short- to medium-term perspective, the sustainability of fiscal policy in the face of rising food and energy prices and their budgetary impact was examined. In addition, at the request of the authorities and key donors, staff assessed the possible revenue implications of an Economic Partnership Agreement (EPA) with the EU.

\footnotetext{
${ }^{6}$ The basic fiscal balance deviated little from what was programmed, while the overall fiscal deficit was 0.8 percent of GDP smaller than programmed. This reflects items traditionally excluded from the program target because they (i) are beyond the authorities' control (e.g., externally-financed investment) or (ii) need to be shielded from spending cuts (e.g., HIPC/MDRI spending).

${ }^{7}$ These delays do not constitute payment arrears or budgetary float under the program definition, as they occurred before the issuance of payment orders. The program definition of the budgetary float is being adjusted to capture these delays in the future.

${ }^{8}$ The staff and the authorities decided to step back from the program discussions for an entire day to discuss and reflect on these issues, based on five PowerPoint presentations given by staff.
} 


\section{B. Growth, Poverty, and Competitiveness}

\section{Senegal's overriding economic challenge is to raise growth and reduce poverty.}

While growth accelerated immediately following the 1994 devaluation, in recent years trend growth has been flat, at around $4 \frac{1}{2}$ percent. Yet, growth has been better in Senegal than in other WAEMU countries. Expansion has been concentrated in services, such as telecommunications, and construction of large infrastructure projects, such as roads. However, the livelihood of about half the population is still closely tied to agriculture which has performed poorly. Cultivation of groundnuts - the main cash crop - is in long-term decline due to lower rainfall, soil degradation, and poor seed and fertilizer management. Although the

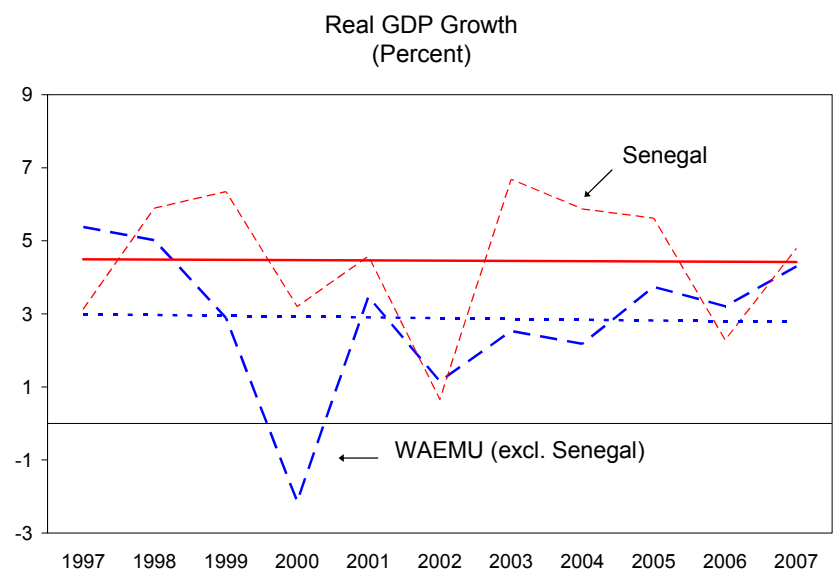
incidence of poverty fell from 68 percent in 1994-95 to 51 percent in 2005-06, it is still high, particularly in rural areas, and several MDGs are likely to be missed (Figure 2 and Table 6).

Senegal, WAEMU, and Sub-Saharan Africa Macroeconomic Indicators, 1996-2008

\begin{tabular}{|c|c|c|c|c|c|c|c|c|c|}
\hline & \multicolumn{3}{|c|}{ 1996-2006 Avg. } & \multicolumn{3}{|c|}{2007 Est. } & \multicolumn{3}{|c|}{2008 Proj. } \\
\hline & & & $\overline{\text { Non-oil }}$ & & & $\overline{\text { Non-oil }}$ & & & Non-oil \\
\hline & SEN & WAEMU & $\mathrm{SSA}^{1}$ & SEN & WAEMU & $\mathrm{SSA}^{1}$ & SEN & WAEMU & SSA $^{1}$ \\
\hline Real GDP growth (percent) & 4.2 & 3.9 & 3.9 & 4.8 & 4.5 & 5.0 & 5.3 & 4.7 & 5.5 \\
\hline Real per capita growth & 1.7 & 1.1 & 1.5 & 2.6 & 1.2 & 2.8 & 3.0 & 1.9 & 3.3 \\
\hline Average inflation (percent) & -0.3 & 2.6 & 12.3 & 5.9 & 2.6 & 8.3 & 4.4 & 2.9 & 7.4 \\
\hline Current account balance (percent of GDP) & -5.5 & -5.5 & -6.2 & -10.4 & -5.6 & -7.5 & -11.1 & -5.5 & -9.0 \\
\hline Foreign reserves (months of imports) & 3.7 & 3.8 & 4.6 & 3.8 & 4.0 & 4.7 & 3.8 & 4.0 & 4.5 \\
\hline Fiscal balance incl. grants (percent of GDP) & -4.0 & -2.4 & -3.4 & -3.5 & -3.0 & 2.2 & -4.9 & -3.0 & -2.0 \\
\hline Government expenditure (percent of GDP) & 24.1 & 20.6 & 28.0 & 27.2 & 22.3 & 29.0 & 28.5 & 22.4 & 29.6 \\
\hline Government revenue (percent of GDP) & 18.9 & 15.9 & 19.3 & 23.4 & 16.7 & 21.7 & 23.5 & 17.7 & 22.0 \\
\hline Period-average REER (percentage change) & -0.4 & 0.7 & -0.4 & 4.6 & 2.7 & $\ldots$ & $\ldots$ & $\ldots$ & $\ldots$ \\
\hline
\end{tabular}

Source: WEO/ WETA database.

${ }^{1}$ Sub-Saharan Africa excluding oil producing countries, Zimbabwe and Senegal.

\section{Estimations by staff suggest that the REER remains broadly in line with}

economic fundamentals (Box 1). This is consistent with the external stability assessment at 
Figure 2. Senegal: Millennium Development Goals, 1990-2015

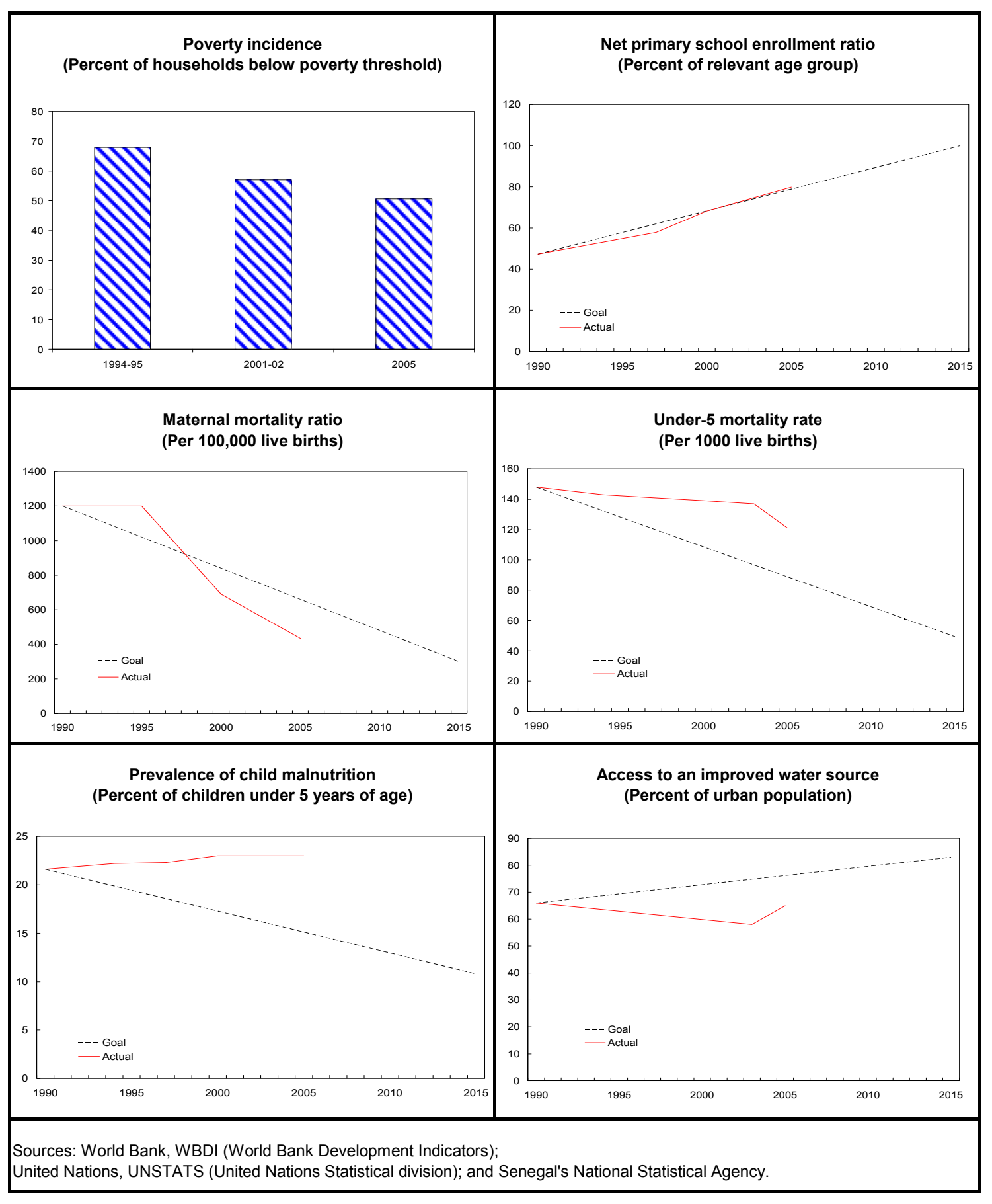


the regional level, which found the WAEMU region's REER not to be misaligned. Other indicators also raise few concerns about the level of the REER. In particular, (i) Senegal's external debt position is sustainable (see DSA in Supplement 1), and (ii) FDI has recently risen considerably, indicating foreign investor confidence.

\section{Box 1. Assessment of Senegal's REER ${ }^{1}$}

\section{Although the REER has somewhat appreciated since 2001, both the fundamental equilibrium exchange rate (FEER) approach and the macroeconomic balance approach find the REER to be broadly in line with its equilibrium level.}

- $\quad$ The FEER approach assumes that the equilibrium REER is related to a set of fundamental factors: terms of trade, productivity, and investment. The relation between the equilibrium REER and these fundamentals is estimated by applying four different econometric techniques. The highest positive and negative deviations of Senegal's actual REER from the estimated equilibrium REER are shown below (right-hand figure). For end-2007, the deviations range from -10 percent to +15 percent.

- $\quad$ The macroeconomic balance approach estimates the REER adjustment needed to close the gap between the projected current account (CA) balance implied by macroeconomic fundamentals (CA norm) and the underlying CA balance which is the CA balance stripped of all temporary factors. The analysis finds that a depreciation of less than 8 percentage points would close the gap, but the statistical error associated with the estimation prevents a conclusive finding of overvaluation.
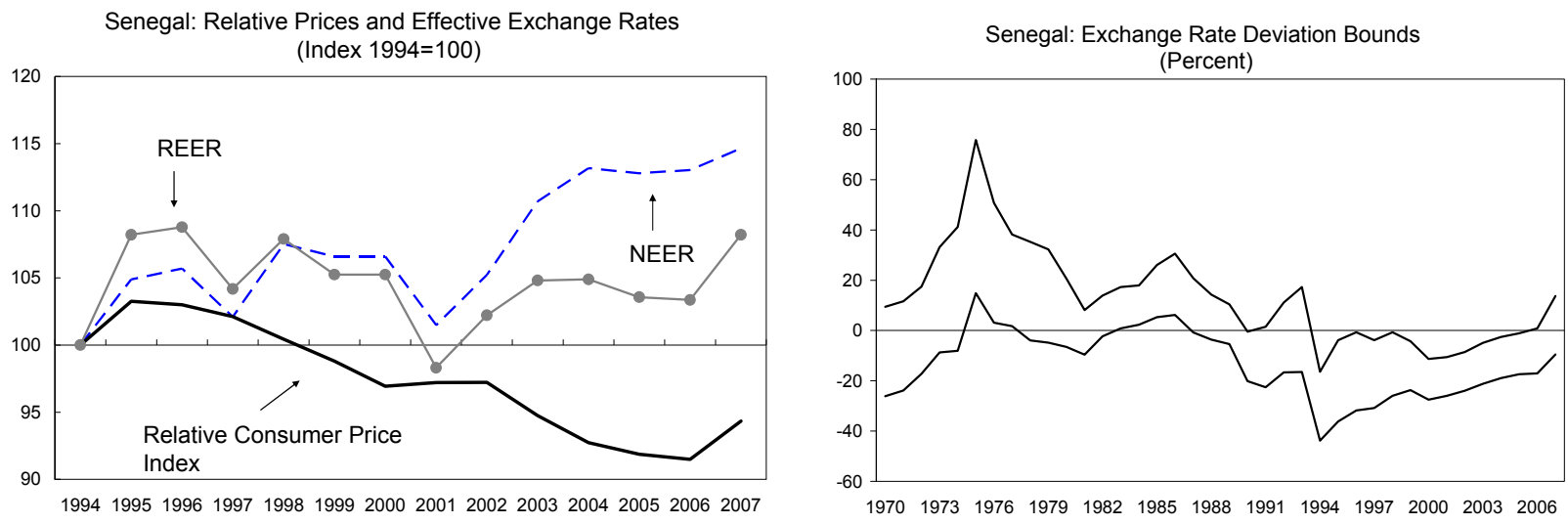

\footnotetext{
${ }^{1}$ This box is based on Chapter I in the accompanying Selected Issues Papers.

2 The bounds are calculated as the maximum percentage deviation of the REER from the equilibrium REER estimates, as estimated using four econometric methods.
} 
11. The authorities agreed with the staff's REER analysis. They pointed out that inflation in Senegal had for years been lower than in its trading partners, which provided a buffer to help absorb the recent nominal appreciation.

\section{Although there is no conclusive evidence that the REER is overvalued, Senegal's} export performance has been poor (Figure 3 ). Net exports have contributed negatively to growth over the last few years, and the near-suspension of ICS's operations depressed exports in 2006-07. More generally, exports are concentrated in products that have faced a difficult demand situation and relatively low price increases. There appear to be significant obstacles to the production of diverse and high-quality products at low cost (Box 2). These are being addressed under the authorities' new approach to growth.

\section{Box 2. Structural Impediments to Higher Competitiveness ${ }^{1}$}

\section{Survey-based indicators rank Senegal among the least competitive countries.}

- $\quad$ Senegal ranks 100 out of 131 countries in the 2007-08 Global Competitiveness Index; the survey identifies a need for Senegal to enhance labor market efficiency, develop financial markets, and invest in health and education.

- $\quad$ The World Bank's 2007-08 Doing Business Index ranks Senegal 162 out of 178 countries; starting a business, registering property, protecting investors, and obtaining credit were seen as the main problems.

- $\quad$ The Bank's 2007 Governance Indicators highlight the need for Senegal to tackle corruption and improve administrative efficiency.

\footnotetext{
${ }^{1}$ See Chapter I in the accompanying Selected Issues Papers.
}

13. The authorities' new approach to growth is intended to increase the economy's growth potential. It centers on improving the business environment and financial intermediation, diversifying and strengthening exports, improving infrastructure and the energy sector, and reforming the labor market-which suffers from multiple ills. ${ }^{1}$ It aims to increase capital and labor utilization and spur productivity growth through the following efforts.

- $\quad$ The Accelerated Growth Strategy (AGS). Adopted in 2007, it has now been passed into law and the implementation decree has been issued (an end-January 2008

\footnotetext{
${ }^{1}$ The Bank's 2007 Country Economic Memorandum (Senegal-Looking for Work-The Road to Prosperity) analyzes these problems in great detail. Among other things, skill levels in the economy are low and labor regulations onerous. Proposed reforms include enhancing education and training and increasing the flexibility of labor regulations, such as with respect to fixed-term contracts (an end-March 2008 PSI benchmark).
} 
Figure 3. Senegal: Export Performance

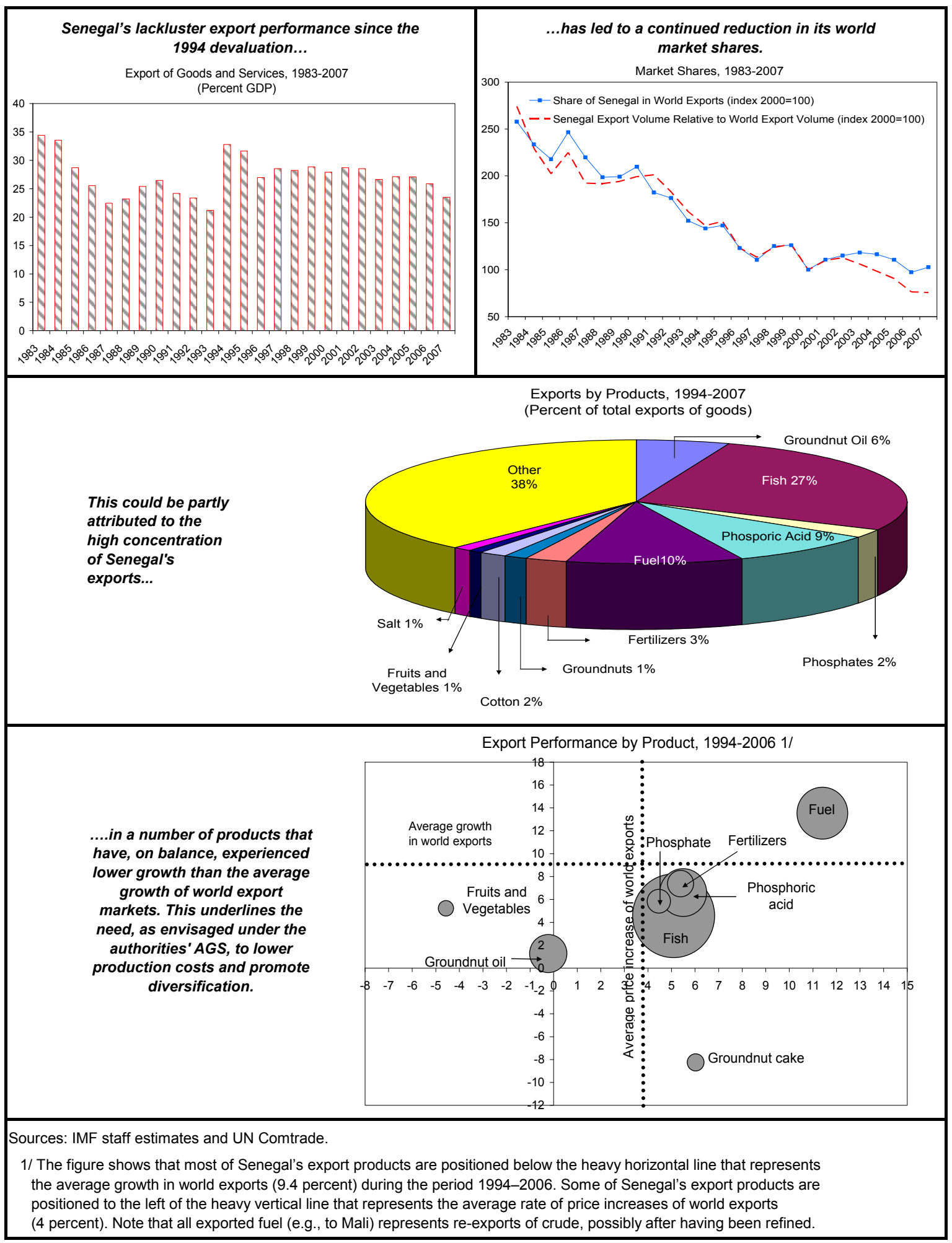


structural benchmark). It focuses on improving the business climate in general and developing specific export sectors. ${ }^{2}$

- $\quad$ Government spending. The authorities aim to channel spending toward areas conducive to growth, such as investment (see Box 3), health, and education. Public investment rose from 6 percent of GDP to 11/1/2 percent of GDP over the past decade and is expected to hover around 12 percent of GDP henceforth. The authorities reiterated their intention to achieve the PRSP target of social spending equal to 40 percent of total spending by 2010 .

- $\quad$ Energy sector reform. The reform recently agreed by the authorities and key development partners should help end energy supply disruptions and the sector's drag on the budget. ${ }^{3}$ It aims to (i) restructure and recapitalize the sector, refine pricing formulas, and cut costs; (ii) improve investment planning; and (iii) strengthen the regulatory framework, foster private sector participation, and implement transparent procurement rules.

\section{Box 3. The Government's Investment Strategy}

An ambitious investment policy is central to the authorities' development strategy. Besides boosting investment in health and education, the authorities are determined to close the infrastructure gap in transport and energy and invest in selected sectors under their AGS.

Senegal's second PRSP featured the large infrastructure projects that the government plans to realize over the next few years. They include an industrial platform (now the special economic zone), the Dakar-Diamniadio highway, and the new airport. These projects are to provide a basis for private sector development and diversify economic activity away from the congested Dakar area. Because they are large and expertise is limited, the authorities are welcoming public-private partnerships (PPPs) to achieve them; the Fund recently provided technical assistance in this area.

Interest in improving public investment planning and evaluation is rising. Faced with no scaling up of aid, limited scope to boost revenue or sell government assets, and a shallow regional financial market, better prioritization of investment is the most promising avenue for the authorities to achieve their development objectives. They will develop directives to improve investment planning and evaluation (a structural assessment criterion—see below).

- $\quad$ Attracting FDI. The authorities have negotiated a range of investment projects with private foreign parties that are projected to bring in a substantial increase in FDI (Box 4).

\footnotetext{
${ }^{2}$ The five sectors are agro-industry, fisheries, electronic customer support services, tourism, and textiles.

${ }^{3}$ The World Bank Board meeting to approve the energy sector development loan is expected for June 2008.
} 


\section{Box 4. FDI in Senegal}

FDI could reach 6 percent of GDP annually in the medium term, quadrupling the average of the last decade. The majority of it originates in the Middle East and India.

A significant portion of FDI is for infrastructure and tourism projects. Some US $\$ 300$ million was invested in hotels and infrastructure for the summit of the Organization of Islamic States in March 2008 - which may help turn Dakar into one of Africa's major conference centers. Dubai World Ports will invest US\$300 million through 2011 to expand the Port of Dakar. JAFZA, another Dubai-based company, has committed to invest up to US\$800 million through 2013 to develop the special economic zone near Dakar. The authorities expect the zone's advanced infrastructure and tax advantages to attract additional FDI.

Exploitation of resources is also attracting investment. Arcelor-Mittal Steel purchased a 25year concession for iron ore mining in 2007 . The company plans to invest US\$2.2 billion to build a new port, renovate railways, and augment health care and infrastructure in nearby villages. The Indian fertilizer company IFFCO has boosted its participation in ICS and is to invest up to US $\$ 200$ million. In both cases, the government is a minority shareholder and will receive a share of production.

\section{The staff concurred that these efforts could raise Senegal's growth potential,} help reduce poverty, and strengthen external competitiveness. It welcomed the general emphasis on investment in infrastructure, health, and education, as well as the authorities' willingness to rely on price signals (e.g., for electricity tariffs) and involve the private sector in developing key sectors and projects. But the staff cautioned that government support for developing the AGS cluster sectors should be limited, subject to thorough cost-benefit studies, and consistent with the need for fiscal prudence. The staff and the authorities agreed that priority should generally be given to the more cross-sectoral measures under the AGS aimed at improving the business environment; the authorities explained the pivotal role of the Presidential Investment

MEFP $q 24$ (refers to relevant MEFP paragraph) Council in this area that was producing desired changes. ${ }^{4}$ Overall, the authorities were hopeful that the reform efforts would help achieve their intended objectives and lead to a rapid improvement in Senegal's competitiveness rankings, similar to the recent successes of countries like Kenya and Ghana.

\footnotetext{
${ }^{4}$ As a striking example, they have reduced the time needed to start a business from 58 days to 48 hours through a one-stop window (guichet unique).
} 


\section{Challenges to Fiscal Sustainability}

\section{Maintaining fiscal sustainability will be instrumental in promoting domestic} stability in the context of Senegal's WAEMU membership. The commitment to fiscal adjustment under the PSI puts Senegal on track to meet, or come close to meeting, the

WAEMU fiscal convergence criteria by the end of the program period. The fiscal DSA (Supplement 1) illustrates the criticality of containing the fiscal deficit to preserve public debt sustainability. This in turn would be key to underpin investment and growth and help maintain domestic stability, by containing demand pressures and avoiding crowding out the private sector.

\begin{tabular}{|c|c|c|c|c|}
\hline & \multirow[t]{2}{*}{2007} & 2008 & 2009 & 2010 \\
\hline & & \multicolumn{3}{|c|}{ Progr. } \\
\hline \multicolumn{5}{|l|}{ Primary Criteria } \\
\hline Basic fiscal balance/GDP ( $\geq 0$ percent) & -0.7 & -1.6 & -1.0 & -0.9 \\
\hline Average inflation ( $\leq 3$ percent) & 5.9 & 4.4 & 2.2 & 2.0 \\
\hline Total debt/GDP ( $\leq 70$ percent) & 23.8 & 26.1 & 27.7 & 29.2 \\
\hline Change in domestic arrears $(\leq 0)$ & 0.0 & 0.0 & 0.0 & 0.0 \\
\hline Change in external arrears $(\leq 0)$ & 0.0 & 0.0 & 0.0 & 0.0 \\
\hline \multicolumn{5}{|l|}{ Secondary Criteria } \\
\hline Wages and salaries/fiscal revenue $(\leq 35 \text { percent })^{1}$ & 29.4 & 28.5 & 28.5 & 28.9 \\
\hline $\begin{array}{l}\text { Domestically financed capital expenditure/fiscal revenue } \\
\text { ( } \geq 20 \text { percent) }\end{array}$ & 35.3 & 34.2 & 36.1 & 38.5 \\
\hline Current account deficit, excluding grants/GDP ( $\leq 5$ percent) & 12.1 & 12.4 & 12.8 & 13.2 \\
\hline Fiscal revenue/GDP ( $\geq 17$ percent) & 20.9 & 21.4 & 21.1 & 20.7 \\
\hline
\end{tabular}

Sources: Senegalese authorities; and Fund staff estimates and projections.

${ }^{1}$ Excluding some contractual wages not classified in the wage bill.

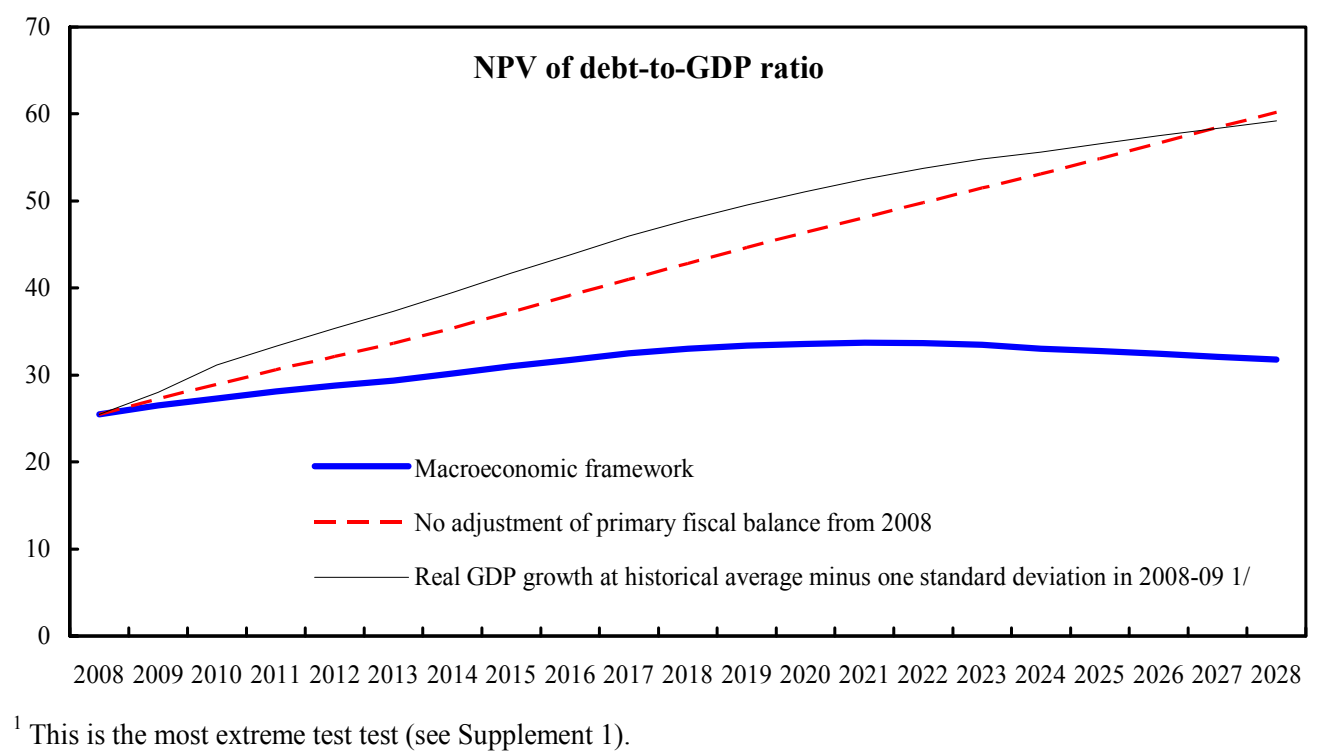

16. The staff identified three distinct challenges to fiscal sustainability, which the authorities agreed needed to be addressed proactively.

- $\quad$ The effect of food and energy price increases. The support measures taken to protect the population from those price increases crowded out the issuance of payment orders for other spending in 2007. On recent trends, the related subsidies are projected to reach 3 percent of GDP in 2008, or one-tenth of all spending. The staff concurred with the authorities that some form of support is necessary in the short run to help 
maintain social calm - which the authorities pointed to as Senegal's most important asset — but the authorities would need to consider affordability, aim for better targeting, and minimize economic distortions. A February 2008 Poverty and Social Impact Analysis (PSIA) conducted by the Fund found that existing subsidies are not well targeted and could be improved (Box 5). The authorities were highly appreciative of the PSIA and the discussion on alternative policy options and indicated they would explore them. They also explained their plans to improve the supply, and lower the costs, of food and energy products. They intend to expand domestic agricultural production, especially of high-yield products such as rice, by improving rural infrastructure and expanding irrigation systems. Energy sector reform is already relatively advanced, and related cost-cutting efforts should yield results in the near future.

\section{Box 5. Rising Food and Energy Prices: Policy Options ${ }^{1}$}

\section{The PSIA analyzed the consumption patterns of Senegalese households and found that} current policy measures are not well targeted.

- $\quad$ Food. The support for rice appropriately benefits most the population's two poorest quintiles. However, for powdered milk and bread, the richer segments gain most from the tax suspensions.

- $\quad$ Energy. Richer household are most adversely affected by energy price increases, both directly and indirectly through the effect on other consumables. The butane gas subsidy benefits better-off households the most, while the lamp oil tax exemption is more beneficial to the poor.

Short-term policy options include: (i) shifting subsidies from butane gas to lamp oil; (ii) keeping some of the current tax suspensions, especially for rice; (iii) instituting a subsidized rate for small electricity users; (iv) redirecting existing agricultural subsidies towards increasing farm productivity and broadening rural job opportunities; and (v) targeting relatively poor groups directly through measures such as school lunches, public works programs, or transport subsidies. All these options should be carefully reviewed regularly to ensure that they do not create unintended adverse behavior.

In the long run, the authorities may want to consider implementation of a conditional cash transfer system. Such systems deliver social protection to the poor in Latin America. They provide money to poor families conditional upon investment in human capital, such as sending children to school or visiting health centers. The PSIA simulations show that such a system could be more cost effective than the current measures to protect the poor in Senegal. Donors could be approached for financial and technical support.

${ }^{1}$ This box is based on Chapter II of the accompanying Selected Issues Papers.

- $\quad$ Prospective trade liberalization under an EPA. Staff analysis suggests that the budgetary impact may be manageable as long as liberalization is spread over time 
(Box 6). The authorities planned to use the results of the staff's work in the preparation of a common regional position.

\section{Box 6. The Budgetary Impact of an Economic Partnership Agreement ${ }^{1}$}

EPAs aim to establish free trade areas between the EU and most ACP countries, including Senegal. The EU proposes asymmetric liberalization while preserving reciprocity: it would dismantle all tariffs and quantitative restrictions on imports from ACP countries, while partner countries would liberalize about 80 percent of EU imports.

Senegal has been an outspoken opponent of EPAs. Like other critics, the Senegalese authorities have argued that EPAs would lead to significant revenue losses and undermine the nascent industrial base of African economies. EPAs have also been criticized for neglecting development.

The staff analysis suggests that Senegal's low reliance on customs duties and strong tax administration are important assets, so it can enter the EPA negotiation with confidence. The share of customs duties in total revenues declined by half over the last decade, and the share of EU imports in total imports has also fallen. This could limit annual EPA-related revenue losses to 1.2 percent of GDP ( 6 percent of total revenue) by the end of the trade liberalization period.

Trade liberalization should thus be phased in over 15-20 years to avoid a fiscal shock. With a gradual approach, (i) revenue losses would average 0.3 percent of GDP annually over the first five years and reach 1.2 percent of GDP only after 2025; (ii) any negative impact on domestic industries would be reduced, as there would be more time to adapt to the changing environment; (iii) the EU's intention to provide compensation for revenue losses would be more feasible; and (iv) greater regional integration would be facilitated. ECOWAS countries have stated their preference to consolidate their regional trade agreement before achieving "substantial" trade liberalization with the EU.

${ }^{1}$ This box is based on Chapter III of the accompanying Selected Issues Papers.

- $\quad$ The revenue implications of DISEZ. While the planned special economic zone has substantial upside potential to promote Senegal's growth and export performance, its downside risks need to be carefully managed. Its substantial tax incentives could undermine Senegal's traditionally strong tax collections, depending on whether taxes paid by new companies offset those lost from existing Senegalese companies moving to the zone. In addition, the roles of the tax and customs administrations in managing the zone and designing anti-fraud measures need to be defined. Against this background, the staff and the authorities agreed on several DISEZ-related measures as structural conditionality for the program (see below).

\section{Macroeconomic Framework and Risks}

17. Senegal's macroeconomic outlook for $\mathbf{2 0 0 8}$ and beyond is broadly favorable, assuming that prudent macroeconomic policies are pursued. Absent any exogenous 
shocks, medium-term economic growth could average $5 \frac{1}{2}$ to 6 percent

(Figure 4). Investment is expected to drive growth in the period ahead, fueled by strong activity in the telecommunications and transport sectors and stepped-up construction activity under largely foreign-financed investment projects. A strong recovery of ICS's operations in the face of unabated world demand for phosphates is expected to support growth and exports. This would help counter the effect of rising food and energy prices, which in 2008 may negatively impact
Senegal : Contributions to Growth, 1996-2013

\begin{tabular}{lcrr}
\hline & 1996-2007 & 2008-13 & Difference \\
\hline & \multicolumn{3}{c}{ (In percent) } \\
Real GDP growth & 4.3 & 5.7 & 1.5 \\
Primary sector & 0.1 & 0.4 & 0.3 \\
Secondary sector & 0.9 & 1.7 & 0.8 \\
Tertiary sector & 3.3 & 3.6 & 0.3 \\
Consumption & 3.3 & 4.0 & 0.8 \\
Private & 2.4 & 3.6 & 1.1 \\
Public & 0.8 & 0.5 & -0.4 \\
Gross fixed investment & 2.6 & 3.6 & 0.9 \\
Private 1/ & 1.6 & 2.4 & 0.8 \\
Public & 1.0 & 1.2 & 0.2 \\
Net exports & -1.6 & -1.9 & -0.2 \\
Exports of goods and non-factor services & 0.0 & 1.6 & 1.6 \\
Imports of goods and non-factor services & -1.6 & -3.5 & -1.9 \\
Labor force 2/ & 1.7 & 1.6 & 0.0 \\
Physical capital 2/ & 2.0 & 2.7 & 0.7 \\
Total factor productivity 2/ & 0.6 & 1.4 & 0.8 \\
\hline Sources: Senegalese authorities; and IMF staff estimates and projections. & & & \\
1/ Including change in inventories. & & &
\end{tabular}
the trade balance by $1 \frac{1}{2}$ percent and $1 \frac{1}{4}$ percent of GDP, respectively. Inflation is projected to revert to its historical level of about 2 percent over the medium term. However, upward pressure on world food and energy prices will likely keep inflation elevated in 2008.

\section{The external current account deficit is projected to be 11 to 12 percent of GDP} over the medium term and to be solidly financed. In addition to support from development partners, an increasingly large share of the current account will be financed through FDI, resulting in a comfortable level of international reserves and external debt sustainability; the DSA points to a low risk of debt distress (Supplement 1). The surge in FDI will contribute to the projected rise in Senegal's investment rate. While domestic saving could gradually benefit from greater business sector profitability - as a result of the envisaged structural reforms - and improved financial sector intermediation - assuming that the vulnerabilities in the financial sector are resolved - the program's fiscal policy stance will be key to supporting domestic saving.

19. The medium-term outlook is subject to downside risks. A sustained reduction in world growth and a slowing of international capital flows emanating from turmoil in global financial markets could be detrimental — although the capital flows to Senegal largely consist of relatively stable FDI. Second, the economy remains vulnerable to shocks, including especially unpredictable price developments in commodities markets and adverse weather and pest conditions affecting agriculture. Third, social and political tensions, possibly exacerbated by food and energy price increases, could weaken the authorities' ability to implement their reform agenda and maintain macroeconomic stability. And fourth, if competing demands for budgetary resources are not well managed or the crowding-out pressure from food and energy price subsidies persists, fiscal outcomes could be less than desirable and undermine domestic stability. 
Figure 4. Senegal: Medium-Term Outlook, 2006-12

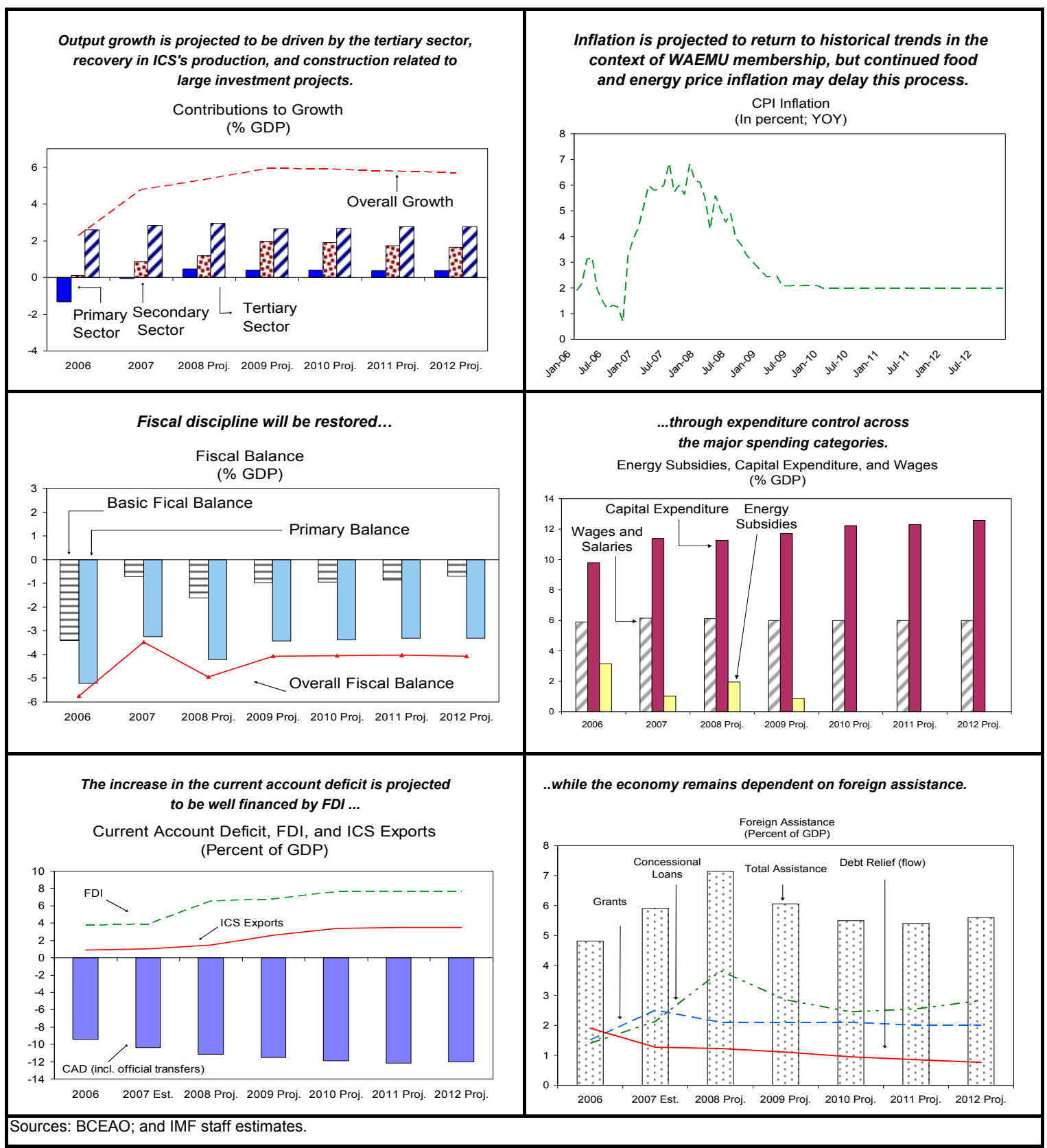




\section{Program Discussions}

\section{A. Overview}

20. The program environment has become more challenging. The rise in food and energy prices and the need to correct last year's fiscal slippages have complicated the envisioned fiscal adjustment path. In addition, Senegal has pressing infrastructure needs but faces financing constraints in the regional financial market and no scaling up of donor aid. A one-time loosening of the zero ceiling on nonconcessional external borrowing for a specific high-yield project is therefore appropriate.

\section{The authorities reiterated their commitment to maintain the PSI's four pillars,} as outlined above in paragraph 1. It was agreed that the detailed October $2007 \mathrm{MEFP}$ would remain the reference point for the authorities' reform efforts under their economic program and be refined through a much shorter MEFP for the first program review (Appendix I). The program's streamlined structural component centers on measures to enhance fiscal governance and transparency. Moreover, some modifications to the definitions of the quantitative program targets are proposed.

\section{B. Fiscal Policy}

\section{The envisaged medium-term fiscal policy stance-a reduction in the overall} fiscal deficit during the program period to 4 percent of GDP-remains appropriate. It will underpin fiscal sustainability, as outlined above, while generally providing sufficient room to address Senegal's development needs. It should also allow the government to further improve the composition of spending, with the aim of achieving the PRSP target of social spending of 40 percent of total spending by 2010 . By contrast, a larger fiscal deficit

could worsen the debt sustainability outlook and result in an undesirable increase in fiscal vulnerability. Moreover, the amount of fiscal space has already increased considerably since 2000 ; further increases in government spending, in particular for investment, could strain the absorptive capacity as long as PFM reforms have yet to come to fruition.

\begin{tabular}{|c|c|c|c|c|c|c|}
\hline \multicolumn{7}{|c|}{$\begin{array}{l}\text { Fiscal Space Indicators for Selected Coun } \\
\text { (Percent of GDP) }\end{array}$} \\
\hline & Ghana $^{1}$ & Malawi $^{2}$ & Rwanda $^{1}$ & Tanzania $^{1}$ & Uganda $^{3}$ & Senegal ${ }^{4}$ \\
\hline Source of fiscal space & 11.0 & 3.3 & 8.3 & 7.8 & -3.0 & 9.0 \\
\hline Domestic contribution & 3.4 & -1.1 & 5.3 & 3.7 & 0.2 & 5.7 \\
\hline Revenues & 3.9 & 1.5 & 5.4 & 2.8 & 1.8 & 4.1 \\
\hline Domestic interest payments & 2.8 & 2.7 & -0.3 & 0.2 & -0.5 & 0.0 \\
\hline Domestic financing (net) & -3.2 & -5.3 & 0.2 & 0.7 & -1.1 & 1.7 \\
\hline External contribution & 7.5 & 4.4 & 3.0 & 4.0 & -3.3 & 3.3 \\
\hline Grants & 3.1 & 2.8 & 2.5 & 1.5 & -1.3 & 0.6 \\
\hline External financing & 4.4 & 1.6 & 0.4 & 2.5 & -2.0 & 2.7 \\
\hline Use of fiscal space & 11.0 & 3.3 & 8.3 & 7.8 & -3.0 & 9.0 \\
\hline Wages & 4.4 & 0.5 & -0.7 & 0.2 & 0.7 & 0.9 \\
\hline Other current spending & 3.6 & 4.0 & 6.3 & 8.1 & 0.7 & 2.4 \\
\hline Development expenditures & 3.1 & -1.2 & 2.7 & -0.4 & -4.4 & 5.8 \\
\hline \multicolumn{7}{|l|}{ Memorandum item: } \\
\hline Pro-poor spending ${ }^{5}$ & 5.9 & 3.8 & 6.7 & 6.8 & 1.6 & 4.0 \\
\hline \multicolumn{7}{|l|}{ Source: IMF staff calculations. } \\
\hline \multicolumn{7}{|l|}{${ }^{1}$ Change over 2000-06. } \\
\hline \multicolumn{7}{|c|}{${ }^{2}$ Change in 2004-06, when substantial fiscal and macroeconomic consolidation took place. } \\
\hline \multicolumn{7}{|c|}{$\begin{array}{l}{ }^{3} \text { Change over 2001-06. Development expenditures include net lending and repayment of domestic arrears. } \\
{ }^{4} \text { Change }\end{array}$} \\
\hline $\begin{array}{l}{ }^{4} \text { Change over } 2000-07 . \\
{ }^{5} \text { Definition may vary across time and }\end{array}$ & & & & & & \\
\hline
\end{tabular}


23. Nonetheless, a fiscal deficit of 5 percent of GDP in 2008 is needed to allow for the settlement of carryover spending from 2007. The authorities attached great importance to a prompt settlement of these payment delays to remove the drag on the private sector. This, together with the projected rise in food and energy subsidies, necessitates a conscientious effort to rein in spending. To ensure that this reprioritization takes place, administrative orders from the Prime Minister and Finance Minister were issued to limit the ability of line ministries to commit new spending, with the former setting the reduced overall budgetary envelopes for both current and capital spending relative to the 2008 budget law and the latter providing the specific budgets for each line MEFP $\uparrow 10$ ministry consistent with the overall envelope; social sectors were excluded from this exercise (prior action). The authorities also blocked commitment authorizations in the SIGFIP system to enforce the order. This expenditure restraint should help lessen demand pressures in certain sectors, thus contributing to macroeconomic stability.

\section{The higher fiscal deficit in $\mathbf{2 0 0 8}$ does not represent a loosening of the}

programmed fiscal policy stance. To the contrary, in aggregate, the combined overall fiscal deficit for 2007 and 2008 is broadly as initially programmed, thus keeping the impact on debt sustainability neutral.

\section{The size of the payment delays warrants a careful stocktaking on the nature of} the underlying spending, including its compliance with budgetary authorizations. ${ }^{1}$ Based on a preliminary census that relied on self-reporting by line ministries and agencies, spending equivalent to 0.2 percent of GDPapparently taken before the program start—was not immediately attributable to existing budget lines. This raises the specter that some of this spending was extrabudgetary. In light of this, the authorities committed to a comprehensive audit by the Inspection Générale des Finances by end-September 2008 to gain a full understanding of all payment delays (structural benchmark). While the backlog of bills should considerably be reduced by then, the audit would lay the basis for a complete and permanent return to normalcy. The authorities agreed that any unauthorized spending would either be regularized in a supplementary budget or rejected by the Minister of Finance. This would reestablish the integrity of the budget framework.

26. Financing constraints in the WAEMU market have become tighter. Banks' excess reserves have fallen sharply in the wake of borrowing by several WAEMU governments. Tapping the regional market will therefore require more planning to make security issues more predictable and interesting to investors MEFP $\ 13$ regarding timing and maturity. The program includes a commitment to develop, jointly with the BCEAO by end-June 2008, a rolling two-year plan for securities issues in the regional

\footnotetext{
${ }^{1}$ The authorities report budgetary costs of the Islamic Conference at 0.4 percent of GDP, some of which was regularized in a supplementary budget after the event.
} 
market, which would be updated each time the market is accessed (structural benchmark). This should help prevent a repeat of past cash-flow problems, lower the risk of payment delays to the private sector, and support the development of the WAEMU market. Importantly, it could also help make monetary operations of the BCEAO more effective, by helping mopping up excess liquidity in a systematic way and providing the central bank with a reliable source of securities for its open market operations.

\section{At the request of the authorities, the program includes a nonzero ceiling on} nonconcessional borrowing (CFAF 80 billion). This is to provide for part of the government's share in a toll road that is being developed as a PPP to link Dakar with Diamniadio where the new airport and DISEZ are located-a prerequisite for making both projects viable. Donors, including the Bank, are providing the rest of the government's share in the project. Donor feasibility studies suggest that its expected return exceeds the anticipated costs of the nonconcessional borrowing. Alternative donor financing for this project is not in sight, and raising funds of this magnitude in the WAEMU market would exceed that market's capacity. Nonetheless, should receipts from privatization or the sale of other government assets become available, the nonzero ceiling would be adjusted downward correspondingly. ${ }^{2}$

\section{Structural Reform Agenda}

28. Structural conditionality is proposed to be streamlined. Six structural assessment criteria or benchmarks are proposed for the PSI's second review. This compares to nine structural conditions in the program's initial phase. ${ }^{3}$

29. Structural conditionality centers on the main pillars of the PSI (MEFP Table 2). ${ }^{4}$ The MEFP contains additional commitments not subject to conditionality. This holds particularly true for reforms in public financial management and efforts to strengthen financial sector supervision and remove impediments to financial intermediation. The following structural conditions have been agreed with the authorities:

\footnotetext{
${ }^{2}$ The authorities are contemplating the sale of their minority share in SONATEL, the profitable telecommunications company. At the time of the mission, they confirmed that they had not yet made a decision. Given the potentially substantial privatization receipts, staff reiterated that the use of the receipts would need to be thoroughly discussed and fully reflected in the macroeconomic framework. Staff also urged the authorities to use a multi-bid tender for the consultancy and divestiture phase, in line with the new procurement framework and the PSI program's emphasis on fiscal transparency and governance.

${ }^{3}$ The reduction in structural conditionality takes into account the Board discussion of the IEO report on structural conditionality and the conclusions of the Ex-Post Assessment for Senegal that the excessive conditionality of past programs should be avoided.

${ }^{4}$ Private sector development is one of the pillars of the PSI, but specific conditionality in this area that would pass the macro criticality threshold proved difficult to derive.
} 
Objective: Support the fiscal policy stance, shore up macroeconomic stability, and strengthen fiscal governance and transparency

- $\quad$ Ringfencing the revenue impact of DISEZ. The authorities will issue an implementation decree to the DISEZ law by mid-November 2008 to (i) prevent firms from specific sectors, in particular regulated telecommunications companies and petroleum companies selling domestically, from MEFP $₫ 17$ moving to the zone; and (ii) limit fraud possibilities through a list of sanctions and the possible exclusion of certain companies from the zone (structural assessment criterion). ${ }^{5}$ These measures were agreed upon based on a study undertaken by the authorities of the possible revenue implications of DISEZ (Box 7).

\section{Box 7. The Dakar Integrated Special Economic Zone (DISEZ)}

In early 2008, the authorities signed an agreement with JAFZA of Dubai to build and operate a special economic zone outside Dakar. The investor will develop the infrastructure, investing US\$800 million, on government-owned land and rent sites to companies that will benefit from a favorable tax regime. The agreement does not contain any government financial guarantees or direct public spending commitments in the zone. As the site is currently barren and undeveloped, it may be two years before the first firms could move into the zone.

The authorities consider the zone an incubator to modernize the economy and accelerate the pace of reform, with significant positive externalities throughout the country. As such, they expect the zone to create thousands of direct and indirect jobs and play an important role in reducing poverty.

Although the authorities expect the zone to be at least revenue neutral, they intend to implement safeguards to this effect. In this context, they carried out a study to assess the zone's potential revenue implications (which met an end-2007 benchmark). The study concluded that the direct tax implications of enterprises moving to the zone would be limited if companies from certain sectors - especially telecommunications-were barred from moving in. The authorities also examined the practices of other economic zones and concluded that entry into, and exit from, the zone will have to be controlled to prevent flagrant fraud and tax evasion. To this end, they intend to enclose the zone with a high fence or wall, allow only very few entry and exit points, administer it rigorously, and introduce transfer pricing rules to combat possibilities for fraud and tax evasion.

- $\quad$ Auditing all payment delays. See paragraph 25 above.

\footnotetext{
${ }^{5}$ In addition, the fiscal and administrative agent role of APIX in relation to the relevant fiscal authorities (customs, revenue authority), as well as specific actions to combat fraud and tax evasion, are to be defined by March 2009 (structural benchmark).
} 
- $\quad$ Strengthening tax administration. By end-October 2008, the authorities will transfer responsibility for direct tax collections for large enterprises from the Treasury to the Revenue Authority (structural benchmark). This has been a long-standing Fund technical assistance and fiscal ROSC MEFP $q 23$ advice. By placing the assessment and recovery of taxes in the same unit, possibilities for tax evasion will be sharply curtailed. This should help safeguard tax collections and lessen the fiscal risks from DISEZ.

- Implementing energy sector reform. As stated above, energy sector reform is macro critical to improve the supply of energy and contain the sector's drag on the budget. The main budgetary impact has emanated from the authorities' hesitation to raise electricity prices in line with the cost structure, which in turn was partially motivated by deficiencies in the existing MEFP $q 22$ formula. Against this background, the authorities will introduce, by August 1, 2008, a new electricity tariff structure that will have rising marginal costs to discourage high consumption and favor low-income households (structural assessment criterion).

Objective: Support implementation of the authorities' new growth model while safeguarding macroeconomic stability

- $\quad$ Strengthening investment planning and evaluation: As elaborated in Box 3, the authorities have become increasingly aware of the need for better investment planning and evaluation. Given limited financing options and planning capacity, better selection and prioritization of investment projects, based on well-defined standards, would allow a focus on high-return projects and raise the productivity of government spending. At the same time, the authorities recognize that the investment program needs to be consistent with their strategic MEFP $\$ 16$ objectives and the macroeconomic framework. To this end, they will develop, by mid-November 2008, directives on improving the planning and evaluation of public investment (structural assessment criterion).

Objective: Eliminate government cash-flow problems, strengthen debt management, and support financial sector development and the BCEAO's monetary operations

- $\quad$ Rationalizing the government's recourse to the regional financial market. See paragraph 26 above. 


\section{Program Monitoring}

30. Three changes are being proposed in program monitoring:

- Given the need to expeditiously eliminate expenditure commitments carried over from 2007, it is proposed that the floor on the basic fiscal balance be raised to CFAF 48 billion for end-June 2008.

- $\quad$ The ceiling on nonconcessional borrowing is proposed to be defined on a cumulative basis and raised from zero to CFAF 80 billion in the fourth quarter of 2008, to help finance the Dakar-Diamniadio toll road. While the expenditure will be made in both 2008 and 2009, the program allows the total amount to be borrowed at once to help the authorities obtain the best financing terms.

- It is proposed that the ceiling on the budgetary float be redefined to monitor a greater range of payment delays. Instead of just capturing expenditures for which a payment order has been issued but not yet paid, the new definition would start at the point where the government receives and validates a bill. Since the new definition is broader, and it will take some time to clear all existing payment delays, the budgetary float ceiling is raised from CFAF 30 billion to CFAF 50 billion at mid-year, before being gradually lowered to CFAF 30 billion by year-end. However, the zero ceiling on arrears is maintained as an additional safeguard.

\section{StAfF Appraisal}

31. Senegal's macroeconomic performance and outlook have improved relative to last year. Economic growth has recovered and prospects are promising, as long as the FDIdriven investment materializes, the restructuring of ICS moves forward, and prudent macroeconomic policies are maintained. This should also help keep the external outlook stable despite a more difficult external environment. However, food and energy price increases could keep inflation above its historic trend in the short run.

\section{Structural reforms will be key to raising competitiveness and improving export}

performance. The authorities' new growth strategy needs to be implemented vigorously to provide the necessary impetus in this regard. The real exchange rate appears to be broadly in line with economic fundamentals, but its development needs to be carefully monitored.

\section{Regarding fiscal policy, the failure to rein in nonpriority spending in 2007 is}

regrettable. Although the basic fiscal balance target was met at end-2007, delaying the issuance of payment orders for spending equivalent to 2 percent of GDP was a worrisome development and onerous for the private sector. The staff strongly urges the authorities to forcefully implement the Prime Minister's administrative order to contain spending commitments in 2008 to allow the full clearance of unpaid bills and maintain fiscal prudence. 
Moreover, if the audit of past expenditure confirms spending without budgetary authorization, the government should take appropriate action expeditiously.

34. The need to limit risks to social peace can justify food and energy subsidies on a temporary basis if they are well-targeted. Nonetheless, the high costs of such measures crowd out other, possibly higher priority, spending. Raising or even maintaining such subsidies over the medium term is thus not sustainable. It is therefore imperative to identify alternative policy measures, in consultation with development partners and other countries in the region. The guiding principles should be budget affordability, better targeting to help those in need, and limiting economic distortions.

\section{The strong implementation of the program's structural component is}

commendable. In particular, several key measures were taken to improve fiscal governance and transparency. This strong performance should be built on to strengthen public financial management even further. In addition, the authorities are encouraged to enhance the legal and regulatory environment for the financial sector, closely supervise it, and work toward the removal of identified obstacles to higher financial intermediation.

36. Notwithstanding the fiscal slippages and the somewhat higher risks to the program stemming from the more challenging external environment, the staff recommends completion of the first program review. On balance, the corrective actions initiated by the authorities, together with the broadening of program targets, would allow past fiscal slippages to be fully corrected in 2008 and provide the basis for resuming the path of fiscal adjustment thereafter. On the basis of the prompt corrective actions taken, the staff also supports the authorities' request for a waiver for the nonobservance of the quantitative assessment criterion on domestic arrears during the first three weeks of the program period. Finally, the program's structural measures, once implemented, will shore up fiscal policy against a variety of risks, including those related to the planned special economic zone.

37. It is recommended that the next Article IV consultation take place within 24 months, subject to the provisions of the decision on consultation cycles in program countries. 
Table 1. Senegal: Selected Economic and Financial Indicators, 2004-13

\begin{tabular}{|c|c|c|c|c|c|c|c|c|c|c|}
\hline & 2004 & 2005 & 2006 & 2007 & 2008 & 2009 & 2010 & 2011 & 2012 & 2013 \\
\hline & & & & Est. & \multicolumn{6}{|c|}{ Proj. } \\
\hline & \multicolumn{10}{|c|}{ (Annual percentage change) } \\
\hline \multicolumn{11}{|l|}{ National income and prices } \\
\hline GDP at constant prices & 5.9 & 5.6 & 2.3 & 4.8 & 5.3 & 5.9 & 5.9 & 5.8 & 5.7 & 5.6 \\
\hline Of which: nonagriculture GDP & 6.0 & 4.8 & 3.9 & 5.7 & 5.3 & 6.1 & 6.1 & 5.9 & 5.8 & 5.7 \\
\hline GDP deflator & 0.5 & 2.3 & 3.4 & 5.2 & 4.0 & 2.3 & 2.2 & 2.2 & 2.2 & 2.2 \\
\hline \multicolumn{11}{|l|}{ Consumer prices } \\
\hline Annual average & 0.5 & 1.7 & 2.1 & 5.9 & 4.4 & 2.2 & 2.0 & 2.0 & 2.0 & 2.0 \\
\hline End of period & 1.7 & 1.4 & 3.9 & 6.2 & 2.9 & 2.1 & 2.0 & 2.0 & 2.0 & 2.0 \\
\hline \multicolumn{11}{|l|}{ External sector } \\
\hline Exports, f.o.b. (in CFA francs) & 9.2 & 4.4 & 0.1 & -2.9 & 23.4 & 9.5 & 10.0 & 7.6 & 7.5 & 6.2 \\
\hline Imports, f.o.b. (in CFA francs) & 9.8 & 15.6 & 9.0 & 12.7 & 23.3 & 11.3 & 10.1 & 8.8 & 8.8 & 7.2 \\
\hline Export volume & 4.4 & -3.8 & -11.9 & -0.3 & 8.4 & 8.9 & 8.1 & 7.9 & 7.2 & 7.2 \\
\hline Import volume & 1.9 & 4.2 & 5.8 & 7.7 & 10.2 & 11.6 & 11.0 & 9.2 & 7.8 & 7.1 \\
\hline Terms of trade (deterioration $(-)$ ) & -3.1 & -2.4 & 10.3 & -7.0 & 1.5 & 0.8 & 2.7 & 0.0 & -0.7 & -0.9 \\
\hline Nominal effective exchange rate & 2.2 & -0.3 & 0.2 & 1.4 & $\ldots$ & $\ldots$ & $\ldots$ & $\ldots$ & $\ldots$ & $\ldots$ \\
\hline \multirow[t]{2}{*}{ Real effective exchange rate } & 0.1 & -1.3 & -0.2 & 4.6 & $\ldots$ & $\ldots$ & $\cdots$ & $\cdots$ & $\cdots$ & $\ldots$ \\
\hline & \multicolumn{10}{|c|}{ (Changes in percent of beginning-of-year broad money, unless otherwise indicated) } \\
\hline \multicolumn{11}{|c|}{ 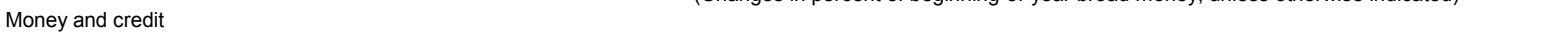 } \\
\hline Net domestic assets & 3.1 & 8.6 & 5.0 & 8.5 & 8.5 & 8.7 & 9.7 & 9.4 & 8.6 & 8.1 \\
\hline Domestic credit & 2.5 & 10.4 & 5.8 & 11.5 & 8.9 & 9.0 & 10.1 & 9.7 & 8.9 & 8.4 \\
\hline Credit to the government (net) & -3.1 & -4.1 & 3.0 & 4.7 & 2.0 & 2.4 & 3.4 & 3.1 & 2.3 & 1.8 \\
\hline \multirow[t]{2}{*}{ Credit to the economy (percentage growth) } & 9.2 & 24.5 & 4.2 & 10.7 & 11.0 & 11.2 & 11.4 & 11.6 & 11.7 & 11.7 \\
\hline & \multicolumn{10}{|c|}{ (Percent of GDP, unless otherwise indicated) } \\
\hline \multicolumn{11}{|l|}{ Government financial operations } \\
\hline Revenue & 18.3 & 19.2 & 19.9 & 20.9 & 21.4 & 21.1 & 20.7 & 20.9 & 21.0 & 21.2 \\
\hline Grants & 2.1 & 1.6 & 1.5 & 2.5 & 2.1 & 2.1 & 2.1 & 2.0 & 2.0 & 2.1 \\
\hline Total expenditure and net lending & 23.3 & 24.1 & 27.5 & 27.2 & 28.5 & 27.3 & 26.9 & 26.9 & 27.1 & 27.3 \\
\hline \multicolumn{11}{|l|}{ Overall fiscal surplus (+) or deficit (-) } \\
\hline Payment order basis, excluding grants & -5.2 & -4.6 & -7.3 & -6.0 & -7.1 & -6.2 & -6.1 & -6.0 & -6.0 & -6.1 \\
\hline Payment order basis, including grants & -3.1 & -3.0 & -5.8 & -3.5 & -4.9 & -4.1 & -4.0 & -4.0 & -4.0 & -4.0 \\
\hline Primary fiscal balance $1 /$ & -1.8 & -2.3 & -5.2 & -3.3 & -4.2 & -3.4 & -3.4 & -3.3 & -3.3 & -3.2 \\
\hline Basic fiscal balance $2 /$ & 0.7 & 0.9 & -3.4 & -0.7 & -1.6 & -1.0 & -0.9 & -0.9 & -0.7 & -0.5 \\
\hline Gross domestic investment & 26.0 & 29.5 & 28.7 & 31.7 & 32.0 & 35.1 & 36.8 & 37.1 & 37.5 & 38.0 \\
\hline Government & 9.7 & 9.9 & 9.8 & 11.4 & 11.3 & 11.7 & 12.2 & 12.3 & 12.6 & 12.9 \\
\hline Nongovernment & 16.3 & 19.6 & 18.9 & 20.3 & 20.8 & 23.4 & 24.6 & 24.8 & 24.9 & 25.1 \\
\hline Gross domestic savings & 13.4 & 14.1 & 11.2 & 11.5 & 10.2 & 12.4 & 13.7 & 14.0 & 14.2 & 14.6 \\
\hline Government & 8.4 & 7.9 & 3.5 & 7.4 & 5.7 & 7.8 & 9.0 & 9.2 & 9.4 & 9.8 \\
\hline Nongovernment & 5.0 & 6.2 & 7.7 & 4.1 & 4.5 & 4.6 & 4.7 & 4.8 & 4.8 & 4.8 \\
\hline Gross national savings & 19.9 & 21.8 & 19.3 & 21.3 & 20.9 & 23.6 & 24.9 & 25.0 & 25.4 & 25.9 \\
\hline \multicolumn{11}{|l|}{ External current account deficit (-) } \\
\hline Including current official transfers & -6.1 & -7.8 & -9.4 & -10.4 & -11.1 & -11.5 & -11.9 & -12.1 & -12.1 & -12.1 \\
\hline Excluding current official transfers & -7.9 & -9.3 & -10.4 & -12.1 & -12.4 & -12.8 & -13.2 & -13.3 & -13.3 & -13.4 \\
\hline Central government domestic debt $3 /$ & 3.5 & 3.3 & 4.3 & 5.6 & 6.1 & 6.9 & 8.2 & 9.3 & 10.0 & 10.5 \\
\hline External public debt (nominal) $3 / 4 /$ & 44.0 & 42.4 & 17.8 & 18.1 & 20.0 & 20.9 & 21.0 & 21.3 & 21.9 & 22.8 \\
\hline External public debt service (percent of exports) $4 /$ & 7.4 & 5.6 & 4.2 & 4.4 & 3.2 & 3.7 & 3.7 & 3.6 & 3.5 & 3.3 \\
\hline External public debt service (percent of government revenue) 4/ & 10.9 & 7.9 & 5.4 & 4.9 & 3.9 & 4.6 & 4.7 & 4.5 & 4.4 & 4.1 \\
\hline Gross domestic product (billions of CFA francs) & 4,243 & 4,582 & 4,846 & 5,344 & 5,856 & 6,348 & 6,872 & 7,430 & 8,028 & 8,662 \\
\hline
\end{tabular}

Sources: Senegalese authorities; and Fund staff estimates and projections.

$1 /$ Defined as total revenue and grants minus total expenditure and net lending, excluding interest expenditure.

2/ Defined as total revenue minus total expenditure and net lending, excluding externally financed capital expenditure, on-lending,

and expenditure financed with HIPC Initiative and MDRI assistance.

3/ Debt outstanding at year-end.

4/ After HIPC and MDRI (from 2006) debt relief. 
Table 2. Senegal: Balance of Payments, 2004-13

\begin{tabular}{|c|c|c|c|c|c|c|c|c|c|c|}
\hline & 2004 & 2005 & 2006 & 2007 & 2008 & 2009 & 2010 & 2011 & 2012 & 2013 \\
\hline & & & & Est. & \multicolumn{6}{|c|}{ Proj. } \\
\hline & \multicolumn{10}{|c|}{ (Billions of CFA francs, unless otherwise indicated) } \\
\hline Current account & -257 & -355 & -455 & -556 & -651 & -732 & -820 & -901 & -968 & $-1,052$ \\
\hline Balance on goods & -521 & -691 & -828 & $-1,062$ & $-1,308$ & $-1,475$ & $-1,624$ & $-1,782$ & $-1,955$ & $-2,111$ \\
\hline Exports, f.o.b. & 798 & 832 & 833 & 810 & 999 & 1,094 & 1,204 & 1,295 & 1,391 & 1,478 \\
\hline Imports, f.o.b. & $-1,319$ & $-1,524$ & $-1,661$ & $-1,872$ & $-2,307$ & $-2,569$ & $-2,827$ & $-3,077$ & $-3,347$ & $-3,589$ \\
\hline Services and incomes (net) & -78 & -70 & -65 & -60 & -16 & -32 & -35 & -20 & -1 & -20 \\
\hline Credits & 437 & 518 & 512 & 530 & 635 & 682 & 733 & 794 & 864 & 922 \\
\hline Debits & -514 & -587 & -577 & -590 & -651 & -714 & -767 & -814 & -865 & -942 \\
\hline Of which: interest on public debt & -41 & -36 & -36 & -22 & -31 & -34 & -37 & -39 & -40 & -49 \\
\hline Unrequited current transfers (net) & 342 & 405 & 437 & 566 & 673 & 774 & 839 & 900 & 988 & 1,079 \\
\hline Private (net) & 270 & 341 & 409 & 498 & 603 & 698 & 756 & 818 & 898 & 973 \\
\hline Public (net) & 72 & 65 & 28 & 69 & 70 & 76 & 82 & 83 & 91 & 105 \\
\hline Of which: budgetary grants & 19 & 12 & 9 & 48 & 25 & 27 & 29 & 24 & 26 & 35 \\
\hline Capital and financial account & 281 & 234 & 512 & 607 & 799 & 794 & 897 & 993 & 1,088 & 1,161 \\
\hline Capital account & 74 & 69 & 1,234 & 182 & 107 & 115 & 124 & 134 & 144 & 156 \\
\hline Private capital transfers & 4 & 6 & 6 & 7 & 8 & 9 & 9 & 10 & 10 & 10 \\
\hline Project grants & 70 & 63 & 64 & 86 & 98 & 106 & 115 & 124 & 134 & 145 \\
\hline Debt cancellation and other transfers $1 / 2$ / & 0 & 0 & 1,163 & 89 & 0 & 0 & 0 & 0 & 0 & 0 \\
\hline Financial account & 207 & 165 & -722 & 424 & 693 & 679 & 772 & 859 & 944 & 1,006 \\
\hline Direct investment & 34 & 28 & 110 & 143 & 316 & 356 & 446 & 483 & 523 & 512 \\
\hline Portfolio investment & -15 & 14 & -11 & 22 & 28 & 26 & 41 & 44 & 46 & 42 \\
\hline Other investment & 188 & 123 & -820 & 260 & 349 & 297 & 285 & 332 & 375 & 452 \\
\hline Public sector (net) & 32 & 33 & $-1,018$ & 97 & 204 & 164 & 136 & 156 & 195 & 233 \\
\hline Of which: disbursements & 157 & 154 & 147 & 156 & 251 & 227 & 213 & 233 & 276 & 323 \\
\hline program loans & 13 & 21 & 39 & 19 & 78 & 33 & 36 & 38 & 41 & 45 \\
\hline project loans & 144 & 133 & 107 & 138 & 133 & 154 & 177 & 195 & 235 & 279 \\
\hline non-concessional loans & 0 & 0 & 0 & 0 & 40 & 40 & 0 & 0 & 0 & 0 \\
\hline amortization & -127 & -122 & $-1,166$ & -54 & -47 & -67 & -77 & -77 & -82 & -90 \\
\hline Of which: non-concessional loans & 0 & 0 & 0 & 0 & 0 & -8 & -16 & -16 & -16 & -16 \\
\hline Private sector (net) & 129 & 84 & 173 & 135 & 145 & 133 & 149 & 176 & 180 & 219 \\
\hline Errors and omissions & 27 & 6 & 25 & 28 & 0 & 0 & 0 & 0 & 0 & 0 \\
\hline Overall balance & 24 & -122 & 57 & 51 & 149 & 62 & 77 & 92 & 120 & 109 \\
\hline Financing & -24 & 122 & -57 & -51 & -149 & -62 & -77 & -92 & -120 & -109 \\
\hline Net foreign assets (BCEAO) & -126 & -9 & -83 & -75 & -167 & -78 & -88 & -101 & -129 & -117 \\
\hline Net use of Fund resources & -23 & -22 & -66 & 0 & 0 & 0 & 0 & -1 & -2 & -2 \\
\hline Purchases & 3 & 3 & 11 & 0 & 0 & 0 & 0 & 0 & 0 & 0 \\
\hline Repurchases & -26 & -24 & -77 & 0 & 0 & 0 & 0 & -1 & -2 & -2 \\
\hline Other & -102 & 12 & -16 & -75 & -167 & -78 & -88 & -99 & -127 & -115 \\
\hline Deposit money banks & 0 & 26 & -37 & 3 & -10 & -11 & -11 & -12 & -12 & -13 \\
\hline Payments arrears (reduction $(-)$ ) & 0 & 0 & 0 & 0 & 0 & 0 & 0 & 0 & 0 & 0 \\
\hline Exceptional financing 2/ $3 /$ & 101 & 105 & 63 & 21 & 29 & 27 & 23 & 21 & 21 & 21 \\
\hline Residual financing gap & 0 & 0 & 0 & 0 & 0 & 0 & 0 & 0 & 0 & 0 \\
\hline \multirow{2}{*}{\multicolumn{11}{|c|}{$\begin{array}{l}\text { Memorandum items: } \\
\text { Current account balance }\end{array}$}} \\
\hline & & & & & & & & & & \\
\hline Including current official transfers (percent of GDP) & -6.1 & -7.8 & -9.4 & -10.4 & -11.1 & -11.5 & -11.9 & -12.1 & -12.1 & -12.1 \\
\hline Excluding current official transfers (percent of GDP) & -7.9 & -9.3 & -10.4 & -12.1 & -12.4 & -12.8 & -13.2 & -13.3 & -13.3 & -13.4 \\
\hline Gross official reserves (billions of CFA francs) & 668 & 662 & 661 & 735 & 903 & 981 & 1070 & 1170 & 1298 & 1414 \\
\hline (months of imports of GNFS) & 4.8 & 4.1 & 3.8 & 3.8 & 3.8 & 3.8 & 3.8 & 3.8 & 3.9 & 3.9 \\
\hline Gross domestic product (billions of CFA francs) & 4,243 & 4,582 & 4,846 & 5,344 & 5,856 & 6,348 & 6,872 & 7,430 & 8,028 & 8,662 \\
\hline
\end{tabular}

Sources: Central Bank of West African States (BCEAO); and Fund staff estimates and projections.

$1 /$ Includes receipts from sale by the government to a Sudanese operator of a telecom license for US $\$ 200$ million in 2007

2/ Reflects MDRI stock debt relief in 2006. Debt relief from the Fund is recorded as a capital transfer. Debt relief from the IDA and the AfDF on the amounts falling due in 2006 is shown as exceptional financing, while debt relief on amounts due in 2007 and beyond is recorded as a capital transfer.

3 / Until 2005, HIPC Initiative flow debt relief granted by the IMF is recorded as a grant, and that granted by the World Bank,

the African Development Bank, Paris Club creditors,and Kuwait is recorded as exceptional financing. 
Table 3. Senegal: Government Financial Operations, 2006-13

\begin{tabular}{|c|c|c|c|c|c|c|c|c|c|c|}
\hline & \multirow[t]{2}{*}{2006} & \multicolumn{2}{|c|}{2007} & \multicolumn{2}{|c|}{2008} & \multirow[t]{2}{*}{2009} & \multirow[t]{2}{*}{2010} & \multirow{2}{*}{$\begin{array}{c}2011 \\
\text { Proj. }\end{array}$} & \multirow[t]{2}{*}{2012} & \multirow[t]{2}{*}{2013} \\
\hline & & Prog. & Est. & Prog. & Proj. & & & & & \\
\hline Total revenue and grants & 1,036 & 1,202 & 1,253 & 1,255 & 1,377 & 1,471 & 1,569 & 1,701 & 1,849 & 2,016 \\
\hline Revenue & 963 & 1,082 & 1,119 & 1,158 & 1,254 & 1,338 & 1,425 & 1,552 & 1,688 & 1,835 \\
\hline Tax revenue & 922 & 1,039 & 1,075 & 1,126 & 1,222 & 1,303 & 1,387 & 1,511 & 1,644 & 1,788 \\
\hline Income tax & 219 & 244 & 232 & 276 & 254 & 280 & 306 & 334 & 364 & 396 \\
\hline Taxes on goods and services & 533 & 577 & 628 & 643 & 697 & 773 & 854 & 937 & 1,031 & 1,129 \\
\hline Taxes on petroleum products & 170 & 217 & 215 & 204 & 272 & 250 & 228 & 240 & 250 & 262 \\
\hline Nontax revenue & 41 & 44 & 44 & 32 & 32 & 35 & 38 & 41 & 44 & 48 \\
\hline Grants & 73 & 120 & 134 & 97 & 123 & 133 & 144 & 149 & 161 & 181 \\
\hline Budgetary & 9 & 41 & 48 & 17 & 25 & 27 & 29 & 24 & 26 & 35 \\
\hline Budgeted development projects & 64 & 79 & 86 & 80 & 98 & 106 & 115 & 124 & 134 & 145 \\
\hline Total expenditure and net lending & 1,331 & 1,452 & 1,456 & 1,513 & 1,667 & 1,730 & 1,847 & 1,999 & 2,173 & 2,366 \\
\hline Current expenditure & 829 & 779 & 842 & 828 & 1,007 & 986 & 1,006 & 1,086 & 1,164 & 1,249 \\
\hline Wages and salaries $1 /$ & 286 & 330 & 329 & 347 & 358 & 381 & 412 & 446 & 482 & 520 \\
\hline Interest due & 42 & 35 & 29 & 41 & 43 & 41 & 45 & 52 & 57 & 70 \\
\hline Of which: external 2/ & 36 & 27 & 22 & 32 & 31 & 34 & 37 & 39 & 40 & 49 \\
\hline Other current expenditure & 500 & 414 & 484 & 440 & 606 & 565 & 549 & 588 & 625 & 659 \\
\hline Transfers and subsidies $3 /$ & 308 & 206 & 252 & 216 & 363 & 306 & 270 & 285 & 303 & 317 \\
\hline Of which: SAR and butane subsidy & 66 & 44 & 55 & 57 & 95 & 46 & 0 & 0 & 0 & 0 \\
\hline Of which: SENELEC & 86 & 0 & 0 & 0 & 20 & 10 & 0 & 0 & 0 & 0 \\
\hline Of which: food subsidies & 0 & 0 & 21 & 0 & 56 & 20 & 0 & 0 & 0 & 0 \\
\hline Goods and services & 186 & 192 & 217 & 209 & 229 & 245 & 266 & 290 & 310 & 330 \\
\hline HIPC and MDRI current spending & 7 & 16 & 15 & 15 & 14 & 14 & 13 & 13 & 12 & 12 \\
\hline Capital expenditure & 475 & 665 & 609 & 685 & 660 & 744 & 841 & 914 & 1,009 & 1,117 \\
\hline Domestically financed & 337 & 464 & 395 & 471 & 429 & 483 & 549 & 594 & 640 & 693 \\
\hline Of which: without transfers to PEs & 337 & 399 & 330 & 426 & 392 & 455 & 549 & 594 & 640 & 693 \\
\hline HIPC and MDRI financed & 26 & 81 & 60 & 75 & 72 & 56 & 52 & 51 & 49 & 49 \\
\hline Non HIPC/MDRI financed & 311 & 384 & 335 & 396 & 356 & 427 & 496 & 544 & 590 & 645 \\
\hline Externally financed & 138 & 201 & 213 & 215 & 231 & 260 & 292 & 320 & 369 & 424 \\
\hline Net lending & 27 & 8 & 5 & 0 & 0 & 0 & 0 & 0 & 0 & 0 \\
\hline Of which: on-lending & 33 & 16 & 10 & 0 & 0 & 0 & 0 & 0 & 0 & 0 \\
\hline Selected public sector entities balance 4/ & 16 & 5 & 17 & 0 & 0 & 0 & 0 & 0 & 0 & 0 \\
\hline Primary fiscal balance $5 /$ & -236 & -210 & -157 & -217 & -247 & -218 & -233 & -246 & -267 & -280 \\
\hline Overall fiscal balance (including grants) & -279 & -245 & -186 & -258 & -290 & -259 & -278 & -298 & -324 & -350 \\
\hline Overall fiscal balance (excluding grants) & -352 & -364 & -320 & -355 & -413 & -392 & -422 & -447 & -485 & -531 \\
\hline Basic fiscal balance 6/ & -165 & -56 & -39 & -51 & -95 & -62 & -65 & -64 & -54 & -46 \\
\hline Financing & 279 & 245 & 186 & 258 & 290 & 259 & 278 & 298 & 324 & 350 \\
\hline External financing & 121 & 159 & 131 & 208 & 252 & 205 & 191 & 210 & 248 & 283 \\
\hline Drawings & 146 & 181 & 156 & 213 & 251 & 227 & 213 & 233 & 276 & 323 \\
\hline Program loans & 39 & 43 & 19 & 78 & 78 & 33 & 36 & 38 & 41 & 45 \\
\hline Project loans & 107 & 138 & 138 & 135 & 133 & 154 & 177 & 195 & 235 & 279 \\
\hline Non-concessional loans for infrastructure development & 0 & 0 & 0 & 0 & 40 & 40 & 0 & 0 & 0 & 0 \\
\hline Amortization due & -58 & -67 & -54 & -53 & -47 & -67 & -77 & -77 & -82 & -90 \\
\hline Of which: Non-concessional loans for infrastructure development & 0 & 0 & 0 & 0 & 0 & -8 & -16 & -16 & -16 & -16 \\
\hline Debt relief and HIPC Initiative assistance $7 /$ & 41 & 32 & 21 & 17 & 29 & 27 & 23 & 21 & 21 & 21 \\
\hline T-bills and bonds issued in WAEMU & -8 & 13 & 8 & 30 & 19 & 18 & 32 & 33 & 32 & 28 \\
\hline Domestic financing & 158 & 85 & 56 & 51 & 38 & 54 & 87 & 88 & 76 & 67 \\
\hline Banking system & 128 & 112 & 92 & 53 & 40 & 56 & 89 & 90 & 78 & 70 \\
\hline Of which: T-bills and bonds & 23 & 155 & 136 & 60 & 52 & 68 & 102 & 104 & 92 & 80 \\
\hline Nonbank financing $8 /$ & 30 & -27 & -36 & -2 & -2 & -2 & -2 & -2 & -2 & -2 \\
\hline Errors and omissions & -1 & 0 & -1 & 0 & 0 & 0 & 0 & 0 & 0 & 0 \\
\hline Financing gap & 0 & 0 & 0 & 0 & 0 & 0 & 0 & 0 & 0 & 0 \\
\hline \multicolumn{11}{|l|}{ Memorandum items: } \\
\hline Arrears, WAEMU definition (billions of CFA francs) & 2 & 0 & 0 & 0 & 0 & 0 & 0 & 0 & 0 & 0 \\
\hline Budgetary float (billions of CFA francs) & 58 & 34 & 33 & 30 & 30 & 30 & 30 & 30 & 30 & 30 \\
\hline Airport travel tax earmarked for new airport (RDIA) & 18 & 22 & 36 & 28 & 38 & 40 & 42 & 44 & 46 & 48 \\
\hline IMF MDRI savings on amortization and interest payments & 20 & 21 & 21 & 13 & 13 & 9 & 7 & 5 & 2 & 1 \\
\hline MDRI debt relief from IDA and AfDF & 1,109 & & & & & & & & & \\
\hline IDA and AfDF MDRI savings on amortization and interest payments & 31 & 27 & 27 & 43 & 30 & 34 & 36 & 38 & 39 & 39 \\
\hline HIPC Initiative expenditure 9/ & 14 & 49 & $\ldots$ & 33 & 44 & 27 & 23 & 21 & 21 & 21 \\
\hline Priority expenditure (percent of total expenditure) $10 /$ & 31.2 & $\ldots$ & 33.2 & $\ldots$ & 33.2 & 36.8 & 39.7 & $\ldots$ & $\ldots$ & \\
\hline Gross domestic product (billions of CFA francs) & 4,846 & 5,247 & 5,344 & 5,728 & 5,856 & 6,348 & 6,872 & 7,430 & 8,028 & 8,662 \\
\hline
\end{tabular}

Sources: Senegalese authorities; and staff estimates and projections.

1/ Excludes project-related wages and salaries, which are included in capital spending, and the salaries of autonomous agencies and health and education contractual workers, which are included in transfers and subsidies.

2/ From 2006, reflects post-MDRI debt service schedule.

3/ Excludes subsidies aimed at sector development policies, which are included in capital spending.

4/ Local governments, autonomous public sector entities (e.g., hospitals, universities), and the civil servants' pension fund (FNR).

5/ Defined as total revenue and grants minus total expenditure and net lending, excluding interest expenditure.

6/ Defined as total revenue minus total expenditure and net lending, excluding externally financed capital expenditure, on-lending, and HIPC/MDRI expenditure.

7/ Until 2005, includes HIPC Initiative debt relief accorded by the IMF, the World Bank, the African Development Bank, and Paris Club Creditors.

$8 /$ Includes receipts from sale of telecom license for $\$ 200$ million in late 2007.

9/ Refers to HIPC-financed capital and other expenditure.

10/ Defined as expenditures on health, education, environment, the judiciary, social development, sewage and rural irrigation. 
Table 4. Senegal: Government Financial Operations, 2006-13

\begin{tabular}{|c|c|c|c|c|c|c|c|c|c|c|}
\hline & \multirow[t]{2}{*}{2006} & \multicolumn{2}{|c|}{2007} & \multicolumn{2}{|c|}{2008} & \multirow[t]{2}{*}{2009} & \multirow[t]{2}{*}{2010} & \multirow{2}{*}{$\begin{array}{l}2011 \\
\text { Proj. }\end{array}$} & \multirow[t]{2}{*}{2012} & \multirow[t]{2}{*}{2013} \\
\hline & & Prog. & Est. & Prog. & Proj. & & & & & \\
\hline & \multicolumn{9}{|c|}{ (Percent of GDP) } & \\
\hline Total revenue and grants & 21.4 & 22.9 & 23.4 & 21.9 & 23.5 & 23.2 & 22.8 & 22.9 & 23.0 & 23.3 \\
\hline Revenue & 19.9 & 20.6 & 20.9 & 20.2 & 21.4 & 21.1 & 20.7 & 20.9 & 21.0 & 21.2 \\
\hline Tax revenue & 19.0 & 19.8 & 20.1 & 19.7 & 20.9 & 20.5 & 20.2 & 20.3 & 20.5 & 20.6 \\
\hline Income tax & 4.5 & 4.7 & 4.3 & 4.8 & 4.3 & 4.4 & 4.5 & 4.5 & 4.5 & 4.6 \\
\hline Taxes on goods and services & 11.0 & 11.0 & 11.8 & 11.2 & 11.9 & 12.2 & 12.4 & 12.6 & 12.8 & 13.0 \\
\hline Taxes on petroleum products & 3.5 & 4.1 & 4.0 & 3.6 & 4.6 & 3.9 & 3.3 & 3.2 & 3.1 & 3.0 \\
\hline Nontax revenue & 0.8 & 0.8 & 0.8 & 0.6 & 0.6 & 0.6 & 0.6 & 0.6 & 0.6 & 0.6 \\
\hline Grants & 1.5 & 2.3 & 2.5 & 1.7 & 2.1 & 2.1 & 2.1 & 2.0 & 2.0 & 2.1 \\
\hline Total expenditure and net lending & 27.5 & 27.7 & 27.2 & 26.4 & 28.5 & 27.3 & 26.9 & 26.9 & 27.1 & 27.3 \\
\hline Current expenditure & 17.1 & 14.8 & 15.8 & 14.5 & 17.2 & 15.5 & 14.6 & 14.6 & 14.5 & 14.4 \\
\hline Wages and salaries & 5.9 & 6.3 & 6.1 & 6.1 & 6.1 & 6.0 & 6.0 & 6.0 & 6.0 & 6.0 \\
\hline Interest payments $1 /$ & 0.9 & 0.7 & 0.5 & 0.7 & 0.7 & 0.6 & 0.7 & 0.7 & 0.7 & 0.8 \\
\hline Other current expenditure & 10.3 & 7.9 & 9.1 & 7.7 & 10.4 & 8.9 & 8.0 & 7.9 & 7.8 & 7.6 \\
\hline Of which: goods and services & 3.8 & 3.7 & 4.1 & 3.6 & 3.9 & 3.9 & 3.9 & 3.9 & 3.9 & 3.8 \\
\hline Of which: transfers and subsidies & 6.3 & 3.9 & 4.7 & 3.8 & 6.2 & 4.8 & 3.9 & 3.8 & 3.8 & 3.7 \\
\hline Of which: energy and food subsidies & 3.1 & 0.8 & 1.4 & 1.0 & 2.9 & 1.2 & 0.0 & 0.0 & 0.0 & 0.0 \\
\hline Capital expenditure & 9.8 & 12.7 & 11.4 & 12.0 & 11.3 & 11.7 & 12.2 & 12.3 & 12.6 & 12.9 \\
\hline Domestically financed & 7.0 & 8.8 & 7.4 & 8.2 & 7.3 & 7.6 & 8.0 & 8.0 & 8.0 & 8.0 \\
\hline Of which: without transfers to PEs & 7.0 & 7.6 & 6.2 & 7.4 & 6.7 & 7.2 & 8.0 & 8.0 & 8.0 & 8.0 \\
\hline Externally financed & 2.8 & 3.8 & 4.0 & 3.8 & 3.9 & 4.1 & 4.2 & 4.3 & 4.6 & 4.9 \\
\hline Net lending & 0.6 & 0.2 & 0.1 & 0.0 & 0.0 & 0.0 & 0.0 & 0.0 & 0.0 & 0.0 \\
\hline Selected public sector entities balance $2 /$ & 0.3 & 0.1 & 0.3 & 0.0 & 0.0 & 0.0 & 0.0 & 0.0 & 0.0 & 0.0 \\
\hline Primary fiscal balance $3 /$ & -5.2 & -4.1 & -3.3 & -3.8 & -4.2 & -3.4 & -3.4 & -3.3 & -3.3 & -3.2 \\
\hline \multicolumn{11}{|l|}{ Overall fiscal balance } \\
\hline Payment order basis, excluding grants & -7.3 & -6.9 & -6.0 & -6.2 & -7.1 & -6.2 & -6.1 & -6.0 & -6.0 & -6.1 \\
\hline Payment order basis, including grants & -5.8 & -4.7 & -3.5 & -4.5 & -4.9 & -4.1 & -4.0 & -4.0 & -4.0 & -4.0 \\
\hline Basic fiscal balance 4/ & -3.4 & -1.1 & -0.7 & -0.9 & -1.6 & -1.0 & -0.9 & -0.9 & -0.7 & -0.5 \\
\hline Financing & 5.8 & 4.7 & 3.5 & 4.5 & 4.9 & 4.1 & 4.0 & 4.0 & 4.0 & 4.0 \\
\hline External financing & 2.5 & 3.0 & 2.4 & 3.6 & 4.3 & 3.2 & 2.8 & 2.8 & 3.1 & 3.3 \\
\hline Domestic financing & 3.3 & 1.6 & 1.1 & 0.9 & 0.6 & 0.8 & 1.3 & 1.2 & 0.9 & 0.8 \\
\hline Errors and omissions & 0.0 & 0.0 & 0.0 & 0.0 & 0.0 & 0.0 & 0.0 & 0.0 & 0.0 & 0.0 \\
\hline Financing gap & 0.0 & 0.0 & 0.0 & 0.0 & 0.0 & 0.0 & 0.0 & 0.0 & 0.0 & 0.0 \\
\hline Memorandum items: & \multicolumn{9}{|c|}{ (Percent of GDP, unless otherwise indicated) } & \\
\hline Grants received, assistance from the HIPC and MDRI Trusts & 1.7 & & $\ldots$ & & . & $\ldots$ & .. & $\ldots$ & $\ldots$ & \\
\hline IMF MDRI savings on amortization and interest payments & 0.4 & 0.4 & 0.4 & 0.2 & 0.2 & 0.1 & 0.1 & 0.1 & 0.0 & 0.0 \\
\hline MDRI debt relief from IDA and AfDF & 22.9 & & $\ldots$ & $\ldots$ & $\ldots$ & $\ldots$ & $\ldots$ & $\ldots$ & $\ldots$ & $\ldots$ \\
\hline IDA and AfDF MDRI savings on amortization and interest payments & 0.6 & 0.5 & 0.5 & 0.8 & 0.5 & 0.5 & 0.5 & 0.5 & 0.5 & 0.4 \\
\hline Airport travel tax earmarked for new airport (RDIA) & 0.4 & 0.4 & 0.7 & 0.5 & 0.6 & 0.6 & 0.6 & 0.6 & 0.6 & 0.6 \\
\hline Priority expenditure $5 /$ & 8.6 & $\ldots$ & 9.0 & $\ldots$ & 9.5 & 10.0 & 10.7 & $\ldots$ & $\ldots$ & \\
\hline Wages and salaries (percent of fiscal revenue) & 29.7 & 30.5 & 29.4 & 30.0 & 28.5 & 28.5 & 28.9 & 28.7 & 28.5 & 28.3 \\
\hline
\end{tabular}

Sources: Senegalese authorities; and Fund staff estimates and projections.

1/ From 2006, reflects post-MDRI debt service schedule.

2/ Local governments, autonomous public sector entities (e.g., hospitals, universities), and the civil servants' pension fund (FNR).

$3 /$ Defined as total revenue and grants minus total expenditure and net lending, excluding interest expenditure.

4/ Defined as total revenue minus total expenditure and net lending, excluding externally financed capital expenditure, on-lending, and HIPC/MDRI expenditure.

5/ Defined as expenditures on health, education, environment, the judiciary, social development, sewage and rural irrigation. 
Table 5. Senegal: Monetary Survey, 2004-08

\begin{tabular}{|c|c|c|c|c|c|}
\hline & 2004 & 2005 & 2006 & $\frac{2007}{\text { Est. }}$ & $\frac{2008}{\text { Proj. }}$ \\
\hline & \multicolumn{5}{|c|}{ (Billions of CFA francs) } \\
\hline Net foreign assets & 676 & 660 & 780 & 851 & 1,028 \\
\hline Central Bank of West African States (BCEAO) & 477 & 487 & 569 & 644 & 811 \\
\hline Commercial banks & 199 & 173 & 210 & 207 & 217 \\
\hline Net domestic assets & 770 & 894 & 972 & 1,121 & 1,289 \\
\hline Net domestic credit & 881 & 1,032 & 1,122 & 1,323 & 1,498 \\
\hline Net credit to the government $1 /$ & 24 & -35 & 11 & 93 & 133 \\
\hline Central bank & 108 & 84 & 45 & 54 & 47 \\
\hline Commercial banks & -94 & -123 & -46 & 21 & 69 \\
\hline Other institutions & 10 & 4 & 12 & 18 & 18 \\
\hline Credit to the economy & 857 & 1,067 & 1,111 & 1,230 & 1,366 \\
\hline Of which: crop credit & 14 & 10 & 9 & 10 & 11 \\
\hline Other items (net) & -111 & -138 & -151 & -202 & -209 \\
\hline Broad money (M2) & 1,446 & 1,553 & 1,751 & 1,972 & 2,317 \\
\hline Currency outside banks & 344 & 378 & 453 & 484 & 525 \\
\hline Total deposits & 1,102 & 1,176 & 1,298 & 1,488 & 1,792 \\
\hline Demand deposits & 563 & 593 & 652 & 770 & 927 \\
\hline \multirow[t]{2}{*}{ Time deposits } & 538 & 582 & 646 & 719 & 865 \\
\hline & \multicolumn{5}{|c|}{ (Change in percentage of beginning-of-period broad money stock) } \\
\hline Net foreign assets & 9.8 & -1.2 & 7.7 & 4.1 & 9.0 \\
\hline BCEAO & 9.8 & 0.7 & 5.3 & 4.3 & 8.5 \\
\hline Commercial banks & 0.0 & -1.8 & 2.4 & -0.2 & 0.5 \\
\hline Net domestic assets & 3.1 & 8.6 & 5.0 & 8.5 & 8.5 \\
\hline Net credit to the government & -3.1 & -4.1 & 3.0 & 4.7 & 2.0 \\
\hline Credit to the economy & 5.6 & 14.5 & 2.9 & 6.8 & 6.9 \\
\hline Other items (net) & 0.6 & -1.8 & -0.8 & -2.9 & -0.4 \\
\hline Broad money (M2) & 12.9 & 7.4 & 12.7 & 12.6 & 17.5 \\
\hline Memorandum items: & \multicolumn{5}{|c|}{ (Units indicated) } \\
\hline Velocity (GDP/M2; end of period) & 2.9 & 3.0 & 2.8 & 2.7 & 2.5 \\
\hline Nominal GDP growth (percentage growth) & 6.4 & 8.0 & 5.8 & 10.3 & 9.6 \\
\hline Credit to the economy (percentage growth) & 9.2 & 24.5 & 4.2 & 10.7 & 11.0 \\
\hline Credit to the economy/GDP (percent) & 20.2 & 23.3 & 22.9 & 23.0 & 23.3 \\
\hline Variation of net credit to the government (from & & & & & \\
\hline previous year; billions of CFA francs) & -40.2 & -59.2 & 46.3 & 81.7 & 39.9 \\
\hline Central bank discount rate (end of period; percent) & 4.50 & 4.50 & 4.75 & 4.75 & $\ldots$ \\
\hline
\end{tabular}

Sources: Senegalese authorities; and Fund staff estimates and projections.

$1 /$ There is a difference in government coverage of the fiscal and the monetary sectors. The change in bank deposits of public entities without counterparts in the fiscal accounts is shown as a memorandum item in Table 3. In 2006, the Fund MDRI-related cancellation of the central bank claim on the government is not reflected in the fiscal accounts, as they are presented on a cash basis. This operation is shown as memorandum item in Table 3 . 
Table 6. Senegal: Millennium Development Goals 1/

\begin{tabular}{|c|c|c|c|c|c|}
\hline & 1990 & 1995 & 2000 & 2005 & 2015 \\
\hline \multicolumn{6}{|l|}{ Goal 1. Eradicate extreme poverty and hunger } \\
\hline \multicolumn{6}{|c|}{ Target 1: Halve, between 1990 and 2015, the proportion of people whose income is less than one dollar a day } \\
\hline Poverty gap at US\$1 a day (percent) & $\ldots$ & 6 & $\ldots$ & $\ldots$ & \\
\hline National household survey poverty incidence 2/ & $\ldots$ & 67.9 & 57.1 & 50.6 & \\
\hline Share of income or consumption by poorest 20 percent & $\ldots$ & 6 & $\ldots$ & $\ldots$ & \\
\hline \multicolumn{6}{|l|}{ Target 2: Halve between 1990 and 2015, the proportion of people suffering hunger } \\
\hline Prevalence of child malnutrition (percent of children under 5 ) & $\ldots$ & $\ldots$ & 23 & $\ldots$ & [10.8] \\
\hline \multicolumn{6}{|l|}{ Goal 2. Achieve universal primary education } \\
\hline \multicolumn{6}{|c|}{ Target 3: Ensure that, by 2015, children will be able to complete a full course of primary schooling } \\
\hline Net primary enrollment ratio (percent of relevant age group) & 47.3 & $\ldots$ & 68.3 & 79.9 & [100.0] \\
\hline Youth literacy rate (percent ages 15-24) & 40.1 & $\ldots$ & $\ldots$ & $\ldots$ & \\
\hline \multicolumn{6}{|l|}{ Goal 3. Promote gender equality and empower women } \\
\hline \multicolumn{6}{|c|}{$\begin{array}{l}\text { Target 4: Eliminate gender disparity in primary and secondary education preferably by } 2005 \text { and } \\
\text { to all levels of education by } 2015\end{array}$} \\
\hline Ratio of girls to boys in primary and secondary education (percent) & 68.5 & $\ldots$ & 83.9 & 87.1 & [100.0] \\
\hline Ratio of young literate females to males (percent ages 15-24) & 60.4 & $\ldots$ & $\ldots$ & $\ldots$ & \\
\hline Share of women employed in the nonagricultural sector (percent) & 26 & $\ldots$ & $\ldots$ & $\ldots$ & \\
\hline Proportion of seats held by women in national parliament (percent) & 13 & $\ldots$ & 12 & 19 & \\
\hline \multicolumn{6}{|l|}{ Goal 4. Reduce child mortality } \\
\hline \multicolumn{6}{|l|}{ Target 5: Reduce by two-thirds, between 1990 and 2015, the under-five mortality rate } \\
\hline Under-5 mortality rate (per 1,000 ) & 148 & 143 & 139 & 121 & [49.3] \\
\hline Infant mortality rate (per 1,000 live births) & 90 & 84 & 80 & 61 & \\
\hline Immunization, measles (percent of children under 12 months) & 51 & 80 & 41 & 75 & \\
\hline \multicolumn{6}{|l|}{ Goal 5. Improve maternal health } \\
\hline \multicolumn{6}{|l|}{ Target 6: Reduce by three-quarters, between 1990 and 2015, the maternal mortality rate } \\
\hline Maternal mortality ratio (modeled estimate, per 100,000 live births) & 510 & $\ldots$ & & 434 & [127.5] \\
\hline Births attended by skilled health staff (percent) & 38 & $\ldots$ & $\ldots$ & 52 & [75] \\
\hline \multicolumn{6}{|l|}{ Goal 6. Combat HIVIAIDS, malaria and other diseases } \\
\hline \multicolumn{6}{|l|}{ Target 7: Halt by 2015 , and begin to reverse, the spread of HIVIAIDS } \\
\hline Prevalence of HIV (percent of population aged 15-24) & $\ldots$ & $\ldots$ & 1.0 & 1.5 & \\
\hline Number of children orphaned by HIVIAIDS & $\ldots$ & $\ldots$ & $\ldots$ & 25,000 & \\
\hline \multicolumn{6}{|c|}{ Target 8 : Halt by 2015 , and begin to reverse, the incidence of malaria and other major diseases } \\
\hline Tuberculosis incidence (per 100,000 people) & 203.3 & $\ldots$ & $\ldots$ & $\ldots$ & \\
\hline Tuberculosis cases detected under DOTS (percent) & $\ldots$ & 61 & 54 & $\cdots$ & \\
\hline \multicolumn{6}{|l|}{ Goal 7. Ensure environmental sustainability } \\
\hline \multicolumn{6}{|c|}{$\begin{array}{l}\text { Target 9: Integrate the principles of sustainable development into policies and programs. Reverse } \\
\text { the loss of environmental resources }\end{array}$} \\
\hline Forest area (percent of total land area) & 49.0 & $\ldots$ & 46.2 & 45.0 & \\
\hline GDP per unit of energy use (2000 PPP U.S. dollar per kilogram oil equivalent) & 5 & 5 & 5 & $\ldots$ & \\
\hline $\mathrm{CO}_{2}$ emissions (metric tons per capita) & 0 & 0 & 0 & $\ldots$ & \\
\hline \multicolumn{6}{|l|}{ Target 10: Halve by 2015 proportion of people without access to safe drinking water } \\
\hline Access to an improved water source (percent of rural population) & $\ldots$ & $\ldots$ & $\ldots$ & 65 & [82] \\
\hline Access to an improved water source (percent of urban population) & 66 & $\ldots$ & 78 & 90 & [95] \\
\hline \multicolumn{6}{|c|}{ Target 11: Achieve significant improvement in life of at least 100 million slum dwellers by 2020} \\
\hline Access to improved sanitation (percent of rural population) & $\ldots$ & $\ldots$ & $\ldots$ & 19.1 & [59] \\
\hline Access to improved sanitation (percent of urban population) & 35 & $\ldots$ & 56 & 60 & [78] \\
\hline \multicolumn{6}{|l|}{ Goal 8. Develop a Global Partnership for Development } \\
\hline \multicolumn{6}{|l|}{ Target 12: Develop and implement strategies for productive work for youth } \\
\hline Fixed line and mobile telephones (per 1,000 people) & 6 & 9 & 44 & $\ldots$ & \\
\hline Personal computers (per 1,000 people) & 2.5 & 7.0 & 15.0 & $\ldots$ & \\
\hline
\end{tabular}

Source: World Bank Staff and World Development Indicators.

$1 /$ The data in italics refer to periods earlier than shown.

2/ Data listed under 2000 are for 2001-02. 
Table 7. Financial Soundness Indicators for the Banking Sector, 2002-07 (Percent, unless otherwise indicated)

\begin{tabular}{|c|c|c|c|c|c|c|}
\hline & $\begin{array}{l}2002 \\
\text { Dec. }\end{array}$ & $\begin{array}{l}2003 \\
\text { Dec. }\end{array}$ & $\begin{array}{l}2004 \\
\text { Dec. }\end{array}$ & $\begin{array}{l}2005 \\
\text { Dec. }\end{array}$ & $\begin{array}{l}2006 \\
\text { Dec. }\end{array}$ & $\begin{array}{l}2007 \\
\text { Dec. }\end{array}$ \\
\hline \multicolumn{7}{|l|}{ Capital Adequacy $1 /$} \\
\hline Capital to risk weighted assets & 16.0 & 12.1 & 11.9 & 11.1 & 13.1 & 13.6 \\
\hline Regulatory capital to risk weighted assets & 15.5 & 11.7 & 11.5 & 10.8 & 12.9 & 13.5 \\
\hline Capital to total assets & 10.3 & 7.8 & 7.7 & 7.6 & 8.3 & 10.4 \\
\hline \multicolumn{7}{|l|}{ Asset composition and quality } \\
\hline Total loans to total assets & 58.3 & 59.6 & 57.1 & 64.0 & 63.8 & 73.3 \\
\hline Concentration: loans to 5 largest borrowers to capital & 104.9 & 141.0 & 131.4 & 179.9 & 103.7 & 88.5 \\
\hline \multicolumn{7}{|l|}{ Sectoral distribution of loans } \\
\hline Industrial & 36.4 & 41.1 & 33.6 & 35.5 & 28.9 & 25.1 \\
\hline Retail and wholesale trade & 22.2 & 19.9 & 19.3 & 17.0 & 18.9 & 14.4 \\
\hline Services, transport and communications & 17.5 & 17.2 & 27.4 & 28.0 & 30.0 & 29.6 \\
\hline Gross NPLs to total loans 1 / & 18.5 & 13.3 & 12.6 & 11.9 & 16.8 & 18.6 \\
\hline Provisions to NPLs & 70.5 & 75.3 & 75.7 & 75.4 & 52.0 & 53.8 \\
\hline NPLs net of provisions to total loans & 5.5 & 3.3 & 3.4 & 3.2 & 8.8 & 8.6 \\
\hline NPLs net of provisions to capital & 30.7 & 27.8 & 25.1 & 27.2 & 67.9 & 60.7 \\
\hline \multicolumn{7}{|l|}{ Earnings and Profitability } \\
\hline Average cost of borrowed funds & 2.2 & 1.8 & 2.0 & 2.0 & 2.2 & $\ldots$ \\
\hline Average interest rate on loans & 9.7 & 8.7 & 11.7 & 11.8 & 11.3 & $\ldots$ \\
\hline Average interest margin 2/ & 7.6 & 6.7 & 9.7 & 9.8 & 9.2 & $\ldots$ \\
\hline After-tax return on average assets & 1.8 & 1.8 & 1.8 & 1.6 & 1.6 & $\ldots$ \\
\hline After-tax return on average equity & 21.1 & 22.1 & 17.6 & 15.8 & 14.6 & $\ldots$ \\
\hline Noninterest expenses/net banking income & 45.5 & 48.9 & 48.7 & 47.9 & 49.4 & $\ldots$ \\
\hline Salaries and wages/net banking income & 20.6 & 21.8 & 21.5 & 21.2 & 21.7 & $\cdots$ \\
\hline \multicolumn{7}{|l|}{ Liquidity } \\
\hline Liquid assets to total assets & 65.1 & 66.5 & 66.4 & $\ldots$ & $\ldots$ & $\cdots$ \\
\hline Liquid assets to total deposits & 82.9 & 81.0 & 82.0 & $\ldots$ & $\ldots$ & $\ldots$ \\
\hline Total deposits to total liabilities & 78.5 & 82.0 & 79.6 & 78.3 & 75.8 & 82.3 \\
\hline
\end{tabular}

Source: Senegalese authorities.

$1 /$ ICS loans backed by government guarantees have a 20 percent weight in the risk-weighted assets. Banks had not made provisions against the overdue amount (about $1 / 2$ of the total).

Total ICS debt with banks is approximately $1 / 3$ of the total capital of the banking system.

2/ Excluding the tax on banking operations. 


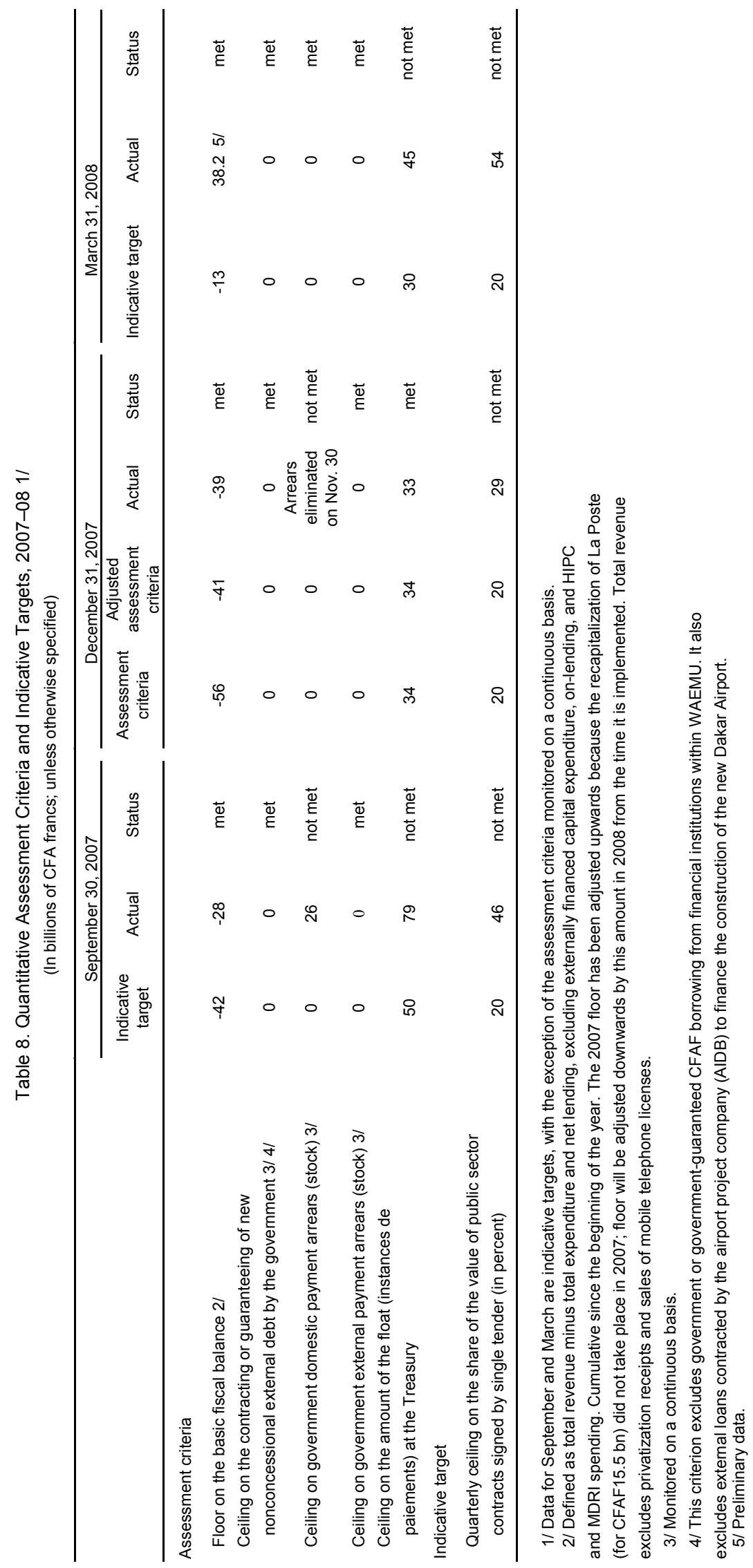


Table 9. Senegal: Structural Conditionality, September 2007-March 2008

Policy Measures Target date of Implementation

Implementation Status

Prior Actions

1. Officially publish the government's decision on an adjustment of electricity prices in the final quarter as specified by decision of the regulatory commission.

Implemented on September 28, 2007

Implemented on September 19, 2007

Implemented on September 14, 2007

End-December 2007

End-December 2007

Completed

5. Amend or revoke Law 2007-13 to modify the

6. Issue a Prime Minister's circular letter in order to implement the new legal framework for procurement with effect from January 1, 2008.

\section{Structural Benchmarks}

7. Complete the study on the impact of tax exemptions resulting from the probable relocation of Senegalese enterprises to the new integrated special economic zone, prior to the signing of the contract with the zone's investor and on the basis of a methodology agreed with Fund staff.

8. Adopt the institutional framework for implementing and monitoring the Accelerated Growth Strategy and make this strategy operational by means of a decree implementing the framework law.

9. Undertake a study on possible means to fight against illegal practices in the accounting profession, as described in paragraph 63.
End-December 2007

Completed

End-January 2008

Completed

End-March 2008

Completed 


\begin{tabular}{llc}
\hline \multicolumn{1}{c}{ Policy Measures } & $\begin{array}{c}\text { Target date of } \\
\text { Implementation }\end{array}$ & Implementation Status \\
\hline $\begin{array}{l}\text { 10. Adopt the decree specifying the conditions for } \\
\text { fixed-term contract [contrat à durée déterminée } \\
(C D D) \text { ], clarifying in which sectors fixed-term } \\
\text { contracts can be renewed repeatedly. }\end{array}$ & End-March 2008 & Completed \\
$\begin{array}{l}\text { 11. Submit to Parliament the new law on } \\
\text { microfinance institutions, as described in } \\
\text { paragraph 66. }\end{array}$ & End-March 2008 & Completed \\
$\begin{array}{l}\text { 12. Complete the forwarding of the government's } \\
\text { end-year Treasury accounts for 2004 and 2005 to } \\
\text { the Audit Office. }\end{array}$ & End-March 2008 & Partially completed \\
\hline
\end{tabular}




\section{Appendix I}

Dakar, Senegal

May 30, 2008

Mr. Dominique Strauss-Kahn

Managing Director

International Monetary Fund

$70019^{\text {th }}$ Street, N.W.

Washington, D.C., 20431

Dear Mr. Strauss-Kahn,

1. The attached Memorandum of Economic and Financial Policies (MEFP) reviews implementation to date of the government of Senegal's macroeconomic and structural program under the country's three-year Policy Support Instrument (PSI), approved by the IMF Executive Board on November 2, 2007. Details of this program were set in the initial MEFP of October 3, 2007. The attached MEFP builds on this initial Memorandum, with particular emphasis on targets and policy prospects for 2008-09.

2. All assessment criteria for the first review under the PSI were met, save for the nonobservance of the continuous quantitative criterion on domestic arrears. Indeed, this criterion could not be met on a continuous basis at the beginning of the program. However, these arrears were quickly eliminated by end-November and the government has since then avoided any accumulation of new arrears. In light of this prompt corrective measure, the government requests a waiver of the missed criterion.

3. The government believes that the policies and measures set forth in the attached MEFP are adequate to achieve the objectives of a PSI program. Given its commitment to these objectives, it will promptly take any additional measures necessary for their achievement. The government will consult with the IMF - at its own initiative or whenever the Managing Director of the IMF requests such a consultation-before the adoption of any such measures or changes to the policies described in the attached Memorandum.

4. The government will provide the Fund with such information as the Fund may request in connection with the progress made in implementing the economic and financial policies and achieving the objectives of the program. 
5. The government authorizes the IMF to publish this letter, the attached Memorandum, and the related Staff Report.

\author{
Sincerely yours, \\ $/ \mathrm{s} /$ \\ Ibrahima Sar \\ Minister of Budget
}

Attachment: Memorandum of Economic and Financial Policies 


\title{
AtTachment I
}

\section{Memorandum of Economic and Financial Policies}

\author{
Dakar, May 30, 2008
}

\section{INTRODUCTION}

1. The government remains committed to higher sustainable growth and making fast progress toward the MDGs. To achieve these goals, it will continue to implement its economic and financial program, which relies on prudent macroeconomic policies and accelerated structural reforms and is supported by the IMF through a three-year Policy Support Instrument (PSI). The government's commitments, as spelled out in the Memorandum of Economic and Financial Policies (MEFP) dated October 3, 2007, will continue to anchor our policies and reforms going forward. This new MEFP describes recent economic developments and program performance, and presents the specific measures and objectives for 2008-09.

\section{Recent Economic Developments and Program Performance}

2. Macroeconomic developments in $\mathbf{2 0 0 7}$ were broadly in line with program projections. Following a marked slowdown in 2006, and although the agricultural sector experienced a second year of output decline, GDP growth is estimated to have rebounded to $43 / 4$ percent, driven by the services and construction sectors. Inflation increased to about 6 percent and the external current account deficit reached about 101/2 percent of GDP, mainly due to large international food and energy price increases.

3. At end-2007, the government met all quantitative assessment criteria except the one on domestic arrears. This criterion could not be met on a continuous basis at the beginning of the program. However, these arrears were quickly eliminated by endNovember.

4. The target on the basic fiscal balance was met, and the overall fiscal deficit was lower than expected, at 31/2 percent of GDP. This mainly reflects under-execution of HIPC and MDRI expenditure ( 0.4 percent of GDP), a surplus of nonfinancial public entities $(0.2$ percent of GDP), and lower-than-expected onlending (0.1 percent of GDP); these lines are excluded from the program criterion definition. However, the government slowed the issuance of payment orders for some expenditure (equivalent to 1.8 percent of GDP) that had already been committed, which made it difficult to honor its commitments to the private sector. The payment delays had become necessary for two main reasons: (i) given the implementation of subsidies and suspensions of certain taxes to contain the impact of food and energy price increases, the government had to slow the issuance of payment orders for other expenditure (mainly investment spending) and (ii) it has committed expenditure in an amount that was higher than what was compatible with the program. 
5. The government has been striving to improve public procurement practices. In spite of this, the indicative ceilings on the share of single-tender public contracts for the last quarter of 2007 and the first quarter of 2008 were missed, because a large number of contracts was approved during this period based on the old procurement code. However, the implementation of the new procurement framework will make it possible to meet this indicator as early as the second quarter 2008.

6. The government succeeded in improving the allocation of spending toward priority sectors in 2007. ${ }^{1}$ The targeted ratio of 33 percent of total expenditure for social spending was met, which represents an increase of 2 percentage points compared to 2006 .

\section{The government made great strides in implementing its structural reform} program. All structural assessment criteria and all but one benchmark through end-March 2008 were met. At this date, the submission of the 2004 and 2005 Treasury accounts to the audit court was only partially completed, since it only covered 9 and 5 accounts (postes comptables), respectively, out of 12. The submission of the 2004 and 2005 accounts will be fully completed by end-April and end-May, respectively. Most other measures not subject to conditionality but specified in the MEFP have been implemented.

\section{Macroeconomic Policies FOR 2008-09}

\section{The macroeconomic outlook for $2008-09$ is broadly favorable despite the more} difficult international perspective. Real GDP growth is projected to reach about $5 \frac{1}{2}$ percent on average over the next two years, reflecting a gradual recovery of ICS's operations, buoyant construction activity, and continued strong growth in the telecommunications and transport sectors. Inflation is projected to return to its historical level of 2 percent over the medium term. Nonetheless, because upward pressures on the prices of food and energy are expected to continue in the short run, the government projects the inflation rate at $4 \frac{1}{2}$ percent in 2008. The external current account deficit should oscillate between 11 and 12 percent of GDP, financed to an increasingly large extent by FDI inflows. External and domestic public debt would increase moderately, reaching about 21 and 7 percent of GDP, respectively, by 2009. While the regional framework for monetary and exchange rate policies will continue to help preserve low inflation, a prudent fiscal policy will remain the key instrument for achieving macroeconomic stability in Senegal and contribute to the WAEMU's external stability.

\footnotetext{
${ }^{1}$ Social expenditures in the context of the program are those of the PRSP. They include spending on health, education, justice, social development, environment, rural hydraulics, and waste management.
} 


\section{A. Fiscal Policy}

\section{Fiscal stance}

9. The government reiterates its commitment to limit the overall fiscal deficit to 4 percent of GDP over the medium term. This deficit level will preserve public debt sustainability. This in turn will be key to underpin investment and growth and also help maintain domestic stability by containing demand pressures and avoiding crowding out the private sector. Nonetheless, the deficit will temporarily rise to 4.9 percent of GDP in 2008, after $3 \frac{1}{2}$ percent of GDP in 2007, in view of the regularization of expenditure committed in 2007. The deficit target will be consistent with a basic fiscal deficit of CFAF 95 billion in 2008 (quantitative assessment criterion). The government will resume its envisaged mediumterm fiscal adjustment path in 2009.

10. The government is aware of the need to curtail nonpriority spending in 2008. To this end, it published on May 19, 2008, an administrative order (circulaire) from the prime minister that limits the authorizations of commitments (engagements) for current expenditure in goods and services to CFAF 229 billion and commitments for domestically-financed capital expenditure to CFAF 429 billion, while at the same time protecting priority expenditures. The administrative order from the prime minister indicates that expenditure related to preceding years will have to be paid in priority. A subsequent administrative order by the Minister of Economy and Finance was issued on May 20, 2008 to provide the breakdown of the authorizations of commitments by ministries consitent with the Prime Minister's administrative order (prior action). The government has provided the IMF staff with the list of envisaged adjustments relative to the 2008 budget laws. The government will block the authorizations of commitments in SIGFIP (the expenditure tracking system) in order to apply the administrative orders.

11. Spending in favor of priority sectors will continue to be increased. This should make it possible to bring social expenditure to 40 percent of total expenditure, or 10.7 percent of GDP, by 2010. Allocations to social sectors will reach 9.5 percent of GDP in 2008 and 10 percent of GDP in 2009. Expenditure in favor of rural areas and infrastructure spending will also be increased. This will be facilitated by the completion of the replenishment of the HIPC and MDRI accounts, in the amount of CFAF 15 billion in 2008, in line with the commitments from the preceding MEFP (paragraph 46), and by the integral use of this amount and all resources freed by these initiatives. The government will use these accounts exclusively for their intended purpose. Finally, in order to facilitate tracking of HIPC and MDRI expenditure, all payment orders related to such expenditure will be assigned the relevant identifying code by end-2008.

\section{Debt Management}

12. To underpin debt sustainability, the government will continue to adhere to the general principle of neither contracting nor guaranteeing external loans on 
nonconcessional terms. Nonetheless, it will need to have recourse to such resources in the amount of about CFAF 80 billion for one high priority project (quantitative assessment criterion). This would allow us to quickly complement donor resources to cover the State's share in 2008 and 2009 for the costs of the Dakar-Diamniadio toll highway, which is being developed under a public-private partnership. Several feasibility studies, including those by the World Bank and the Agence Française de Développement, have shown that the return of this project exceeds the cost of the nonconcessional borrowing for the government's share. The government will consult with IMF staff well in advance for any additional future exceptions to this assessment criterion. The principles for such borrowing are stipulated in paragraph 22 of the preceding MEFP.

\section{Consistent with earlier commitments, other aspects of debt management will}

also be strengthened. First, the government will develop before end-June 2008 a rolling two-year program of issuance of government securities, in collaboration with the BCEAO (structural benchmark). The program will aim at lengthening the maturity profile of securities and make market access more frequent and regular. It will be updated after each security is issued and will be consistent with the macroeconomic framework under the PSI. Such a program of issuance of government securities should help limit the government's cash flow problems and facilitate the development of regional financial markets. Second, starting in December 2008, the semiannual debt sustainability analysis will include an analysis of risks posed by contingent liabilities stemming from government guarantees, PPPs, and the operations of public enterprises.

\section{Elimination of payment delays}

14. Based on a preliminary stocktaking exercise completed in May 2008, we have identified extrabudgetary spending and payment delays in the early stages of the expenditure chain. Spending without budget appropriation, equivalent to about 0.2 percent of GDP, may have taken place in 2007 and early 2008 and will be fully regularized in a new supplementary budget, unless the Minister of Economy and Finance (MEF) considers that it does not respect the rules governing public expenditure as stipulated by article 18 of the 2007 budget law. Payment delays in the early stages of the expenditure chain related to prior fiscal years and amounting to 1.8 percent of GDP will be fully settled during 2008. These delays have arisen because the government slowed the issuance of payment orders, while continuing to commit to expenditures. The preliminary stocktaking exercise will be supplemented by end-September 2008 with a thorough audit of the State's payment delays by the financial audit inspectorate of the MEF (Inspection Générale des Finances), which will, if need be, be assisted by a specialized private audit firm (structural benchmark). In addition, the government will take appropriate corrective actions to restore the integrity of the budgetary framework and support private sector development and the soundness of the banking system. For this purpose, it will: 
a. Not accumulate any domestic payment arrears under the WAEMU definition (continuous quantitative assessment criterion).

b. Limit the stock of the budgetary float, defined as expenditure for which a bill has been received and recognized (dépenses liquidées) but remains unpaid (quantitative assessment criterion).

c. Limit the stock of expenditure committed (dépenses engagées) for which a bill has not been recognized (dépenses non liquidées) .

d. Improve the monitoring of budget execution and the expenditure chain by:

(i) installing the ASTER accounting software at the Treasury and connecting it to the SIGFIP software of the Ministry of Economy and Finance by the end of the second quarter 2009; and (ii) in the meantime, using the recent extension of SIGFIP to the payment phase.

e. Limit Treasury advances to 10 percent of total annual spending on nonwage current expenditure and domestically-financed capital expenditure and to no more than CFAF 30 billion at any given point.

\section{STRUCTURAL ReFormS}

\section{A. Fiscal Structural Reforms}

\section{Fiscal structural reforms will remain at the core of our structural reform}

program. This should enable us to improve the productivity of public expenditures, enhance fiscal transparency, and better assess, contain, monitor, and report budgetary risks.

\section{Strengthening investment planning and evaluation}

16. The government will continue to honor earlier commitments to strengthen public investment planning and evaluation and improve the framework for the implementation of PPPs. This will allow it to enhance efficiency gains and better implement its ambitious investment program that is to help lay the foundation for strong future economic growth. During 2008-09, the following measures will be given priority:

a. The government will issue, by November 15, 2008, a prime ministerial administrative order that will stipulate guidelines to strengthen public investment planning and evaluation. These guidelines will be developed in a participative way by representatives of the State's services involved in investment planning and evaluation. The guidelines will aim to describe the procedures and institutional responsibilities to ensure: (i) consistency of investment projects with strategic objectives and between investment projects; (ii) consistency of investment programs with the medium-term macroeconomic framework; and (iii) the establishment of standards for project analysis according to the size of the projects, as well as the 
respect of these standards in order to facilitate the selection of the best projects (structural assessment criterion).

b. As planned under the Accelerated Growth Strategy (AGS), and in line with the recommendations of the Presidential Investment Council (CPI), the government will prepare, by end-June 2008, a modification to the Law 2004-13 of March 1, 2004, on Build-Operate-Transfer (BOT) contracts. In particular, this modification will aim at allowing, in case of dispute, international arbitration and the choice of the third arbiter by a neutral institution rather than the Dakar regional court.

\section{Large investment projects}

\section{The government will continue to ensure transparency and efficiency in the} execution of its large investment projects. It considers these projects as key to increase the growth potential of the Senegalese economy. Earlier commitments regarding the airport project and the Dakar integrated special economic zone (DISEZ) will continue to be observed. With respect to DISEZ, the government is determined to continue the preparations for making the zone operational by 2010 . At the same time, it is committed to creating a zone that generates value added without weakening the government's revenue base. The zone should therefore help generate a rise in growth and employment while preserving macroeconomic stability. To this end:

a. The government will adopt an implementation decree on the DISEZ law by November 15, 2008. The decree will stipulate that (i) regulated enterprises in the telecommunications sector, i.e., telecommunications operators, will be excluded from coverage of the DISEZ law; (ii) enterprises in the hydrocarbons sector will be authorized in the zone only if they are exclusively dedicated to exporting; and (iii) as envisaged under article 30 of the DISEZ law, a list of sanctions will be implemented in case the regulations governing the zone are violated, especially with a view to limiting fiscal fraud and having the possibility of excluding enterprises in case of major breaches of these regulations (structural assessment criterion).

b. With a view to ensuring the efficiency, equity, and viability of the tax system, and to limit possibilities for fraud, APIX, the Revenue Authority (DGID) and the Customs Authority (DDI) will agree, by end-March 2009, on memoranda of understanding (protocoles d'accord) that will stipulate, among other things: (i) their respective rights and responsibilities; (ii) the specific measures to fight against fraud and tax evasion; and (iii) the rules for resolving conflict (structural benchmark).

c. In order to safeguard the fiscal integrity of the zone, the government will secure it with a wall or a fence and set up a very limited number of access roads. The government will implement a GPS tracking system to track transport vehicles entering and leaving the zone. 
d. The government will prepare directives on transfer pricing, based on OECD guidelines.

\section{Procurement}

18. A new procurement framework is now in place, and the government is determined to apply it forcefully. Specifically:

a. The government will redouble its efforts to respect the quarterly indicative target on the share of government contracts awarded on a noncompetitive basis, set at 20 percent of all contracts, including those entered into by agencies.

b. Starting at end-June 2008, the government will publish on the website of the central directorate for public procurement (DCMP) the list of contracts awarded quarterly.

c. No public procurement will be allowed unless it has been included in the procurement plans submitted to the DCMP.

d. Starting at end-June 2008, the procurement regulatory agency (ARMP) will conduct audits and surveys of government contracts, as described in the earlier MEFP.

\section{Monitoring risks inherent to public sector operations and fiscal transparency}

\section{In order to strengthen the monitoring of fiscal risk and enhance fiscal}

\section{transparency, the government will:}

a. Reflect in an annex to the Budget Law, starting with the 2009 Budget Law, the fiscal risks associated with public sector operations, the financial flows related to quasifiscal activities of public or private enterprises and public entities, as well as a quantitative assessment of tax exemptions, in aggregate terms, for the last available fiscal year.

b. Forward the end-year Treasury accounts (Comptes de gestion) for 2006 to the audit court by end-August 2008 and those for 2007 by end-March 2009.

c. Forward the draft budget review law (lois de règlement) for 2004 to the audit court before end-June 2008 and those for 2005-06 before end-December 2008.

d. Submit to Parliament by end-October 2008 a law establishing the conditions under which government agencies may be created and specifying the objectives, decisionmaking bodies, and mechanisms for controlling their operations and budget execution procedures.

e. Provide the audit court, in the context of the 2009 Budget Law, with the necessary resources to obtain additional premises with sufficient space - through renting, buying or building offices - and to hire 30 new judges and prosecuting attorneys for each audit chamber. 


\section{Alleviating price increases}

20. Helping the population cope with the impact of rising food and energy prices is a national priority. In doing so, the government intends to strike the appropriate balance between safeguarding macroeconomic stability and providing immediate temporary relief to those in need. To this end, the government will examine options for improving the targeting of existing relief measures and containing their impact on the budget.

21. With a more medium-term perspective, the government will focus on improving the supply and lowering the costs of food and energy products. The agricultural sector is also vital to the fight against poverty. The government attaches importance to expanding domestic agricultural production, in particular of high-yield products, such as rice. To this end, it will work with farmers to improve infrastructure, particularly irrigation and storage systems; increase competition; and redirect agricultural subsidies to help enhance farm productivity. In the same vein, energy sector reform is aimed at enhancing production and generating cost reductions which the government intends to gradually pass on to consumers.

\section{Energy sector reform}

22. Energy sector reform is crucial to improve the supply of energy to the economy and contain fiscal risks. The government has finalized the main elements of its reform program - supported by the World Bank and other donors - with the signature of the sectoral policy letter. The government is guided by the principle of truth in pricing and the implementation of energy savings and efficiency gains. To support the reform program, it will:

a. By August 1, 2008, adopt and make effective the new tariff structure for electricity, which provides a progressive pricing structure - which would encourage energy savings - and incorporates lower tariff adjustments for low-income consumers (structural assessment criterion).

b. Announce by August 1, 2008, an increase in electricity prices based on the exceptional revision to the existing formula.

c. Complete the recapitalization of SENELEC by 2009. In 2008, budgetary resources of CFAF 37 billion will be provided to SENELEC for this purpose.

d. The government remains committed to eliminating the butane subsidy by end-July 2009. In the meantime, butane prices will be adjusted to limit the annual subsidy to CFAF 32 billion in 2008 . 


\section{Tax administration}

23. The Revenue Authority (DGID) has followed a roadmap for further enhancing the efficiency of tax administration. The priority measures for the coming months are to:

a. Extend by end-December 2008 the tax management software (SIGTAS) to all taxes for all Dakar collection centers.

b. Make the interface between the information systems of the three tax revenuecollecting offices (DGID, DGD, and DGCPT) fully operational by February 2009.

c. Adopt by October 31, 2008, all the legal texts and regulations necessary for the effective transfer of direct State tax collection responsibilities from the Treasury to the DGID starting January 1, 2009 (structural benchmark). This requires modification of the Tax Code, the decree regulating public accounting, and the ministerial orders relative to the organization of the DGID and the DGCPT. The integration of tax assessment and collection in the same entity will facilitate the fight against fraud and safeguard tax revenues. A schedule for this transfer along the following lines will be published:

(i) Effective January 1, 2009 for the region of Dakar: Transfer of the collection of the income tax (IR) by salary deduction, taxes on revenue by professionals (bénéfices non commerciaux et autres sommes payées à des tiers), profits taxes (IS), and income taxes owed by the taxpayers monitored by the large taxpayer unit (CGE).

(ii) Effective January 1, 2010: Transfer of the IS and IR owed by other taxpayers in the region of Dakar.

(iii) Effective January 1, 2011: Transfer of the IS and IR owed by taxpayers located outside of Dakar.

\section{B. Accelerated Growth Strategy and Development of the Private Sector}

\section{The Accelerated Growth Strategy (AGS) will remain the anchor of the reform} agenda and of priority measures to enhance the growth potential of the Senegalese economy. Implementation of this strategy is now on track with the adoption of framework law 2008-03 of January 8, 2008, and its implementation decree 2008-56 of January 29, 2008 which sets out the organizing and functioning rules of the institutional framework for implementing the AGS. The institutional set-up will be operational by end-May 2008. In addition, the framework to assist the private sector will be restructured and strengthened in order to better complement the AGS. The President's Investment Council (CPI) is the appropriate forum to advance the reform agenda for transversal measures, and progress is assessed in weekly meetings of the relevant working groups. 


\section{Financial Sector Reforms}

25. The government is determined to safeguard the soundness of the financial system and enhance its contribution to the economy. To this end, and consistent with earlier commitments, the government will:

a. Issue the implementation decrees for the new law on microfinance institutions by end-June 2008 and strengthen the oversight unit within MEF.

b. Submit to Parliament by end-December 2008 the new regional law against the financing of terrorism.

c. Implement all decisions and recommendations of the WAEMU regional banking commission.

d. Work closely with the BCEAO and the WAEMU regional banking commission to limit the impact of the ICS restructuring plan on the banking system.

e. Continue to discuss with the Association of Senegalese Banks a reduction in the tax on banking operations (TOB) or its replacement with the VAT, in order to find a solution that would facilitate access to credit while limiting the impact on public finances.

f. During the current year, train judges specialized in economic and financial matters and improve procedures for real estate sales.

\section{Program Monitoring}

26. Quantitative assessment criteria for end-June 2008 and end-December 2008, and indicative targets for end-September 2008 were set to monitor program implementation in 2008 (see Table 1 of the annexed Technical Memorandum of Understanding-TMU). The government and IMF staff also agreed on the prior action, structural assessment criteria, and benchmarks listed in Table 2 of the TMU. The second and third reviews are scheduled to take place by end-December 2008 and by end-June 2009. The government understands that completion of the second review of the program is contingent upon the observance of the assessment criteria set for end-June 2008 and the structural assessment criteria for the period through November 15, 2008. 


\section{ATTACHMENT II}

\section{TeChNiCAL MEMORANDUM OF Understanding}

\section{Dakar, May 30, 2008}

1. This technical memorandum of understanding (TMU) defines the quantitative and structural assessment criteria, indicative targets, and structural benchmarks on the basis of which the implementation of the Fund-supported program under the Policy Support Instrument (PSI) will be monitored in 2008 and 2009. The TMU also establishes the terms and timeframe for transmitting the data that will enable Fund staff to monitor program implementation.

\section{Program Conditionality}

2. The quantitative assessment criteria for June 30, 2008 and December 31, 2008 and the quantitative indicators for September 30, 2008, are shown in Table 1. The prior action, structural assessment criteria, and structural benchmarks established under the program are presented in Table 2 .

\section{Definitions, Adjusters, AND DAta Reporting}

\section{A. The Government}

3. Unless otherwise specified below, the government is defined as the central administration of the Republic of Senegal and does not include any local administration, the central bank, or any government-owned entity with a separate legal personality (e.g., public universities and hospitals).

\section{B. Basic Fiscal Balance (Program Definition)}

\section{Definition}

4. The basic fiscal balance (program definition) is the difference between the government's budgetary revenue and total expenditure and net lending, excluding externallyfinanced capital expenditure (financed by donors), drawings on on-lent loans (except on-lent loans to the energy sector financed through donor budget support), and expenditure funded with HIPC- and MDRI-related resources. Budgetary revenue excludes privatization receipts and sales of mobile telephone licenses or other government assets. Government expenditure is defined on a payment order basis. The assessment criterion is set as a floor on the cumulative basic fiscal balance since the beginning of the year. 


\section{Example}

5. The floor for the basic balance (program definition) as at December 31, 2008 is minus CFAF 95 billion. It is calculated as the difference between budgetary revenue (CFAF 1254 billion) and total expenditure and net lending (CFAF 1667 billion), excluding externally financed capital expenditure (CFAF 231 billion), drawings on on-lent loans (CFAF 0 billion), and expenditure funded with HIPC- and MDRI-related resources (CFAF 87 billion).

\section{Reporting requirements}

6. During the program period, the authorities will report monthly to Fund staff provisional data on the basic fiscal balance (program definition) and its components with a lag of no more than 45 days. Data on revenues and expenditure that are included in the calculation of the basic fiscal balance, and on expenditure financed with HIPC- and MDRIrelated resources, will be drawn from preliminary treasury account balances. Final data will be provided as soon as the final balances of the treasury accounts are available, but not later than two months after the reporting of the provisional data.

\section{Government Domestic Payments Arrears}

\section{Definition}

7. In line with the WAEMU definition, domestic payment arrears are government expenditures cleared for payment (dépenses ordonnancées) but not paid during a period of 90 days after the date the payment order (ordonnancement) was cleared. The assessment criterion on domestic payment arrears will be monitored on a continuous basis.

\section{Reporting requirements}

8. The authorities will report to Fund staff any accumulation of domestic payments arrears, as defined above, as soon as incurred. The government will also report to Fund staff on a monthly basis and with a maximum delay of 60 days all committed expenditure (dépenses engagées) and all certified expenditure that have not yet been cleared for payment (dépenses liquidées non encore ordonnancées).

\section{Budgetary Float}

\section{Definition}

9. The budgetary float (instances de paiement) is defined as the outstanding stock of government expenditure for which bills have been received and validated (dépenses liquidées) but not yet paid. The assessment criterion is set as a ceiling on the budgetary float, monitored at the end of the quarter. 


\section{Reporting requirements}

10. The authorities will report to Fund staff the amount of budgetary float on the same basis as described in paragraph 8 of this TMU.

\section{E. Government External Payment Arrears}

\section{Definition}

11. External payment arrears are defined as the sum of payments owed and not paid on the external debt contracted or guaranteed by the government. The definition of external debt given in paragraph 13 is applicable here. The assessment criterion on external payment arrears will be monitored on a continuous basis.

\section{Reporting requirements}

12. The authorities will report to Fund staff any accumulation in external payment arrears as soon as the due date is passed.

\section{F. Contracting or Guaranteeing of New Nonconcessional External Debt by the Government}

\section{Definition}

13. This assessment criterion applies not only to debt as defined in Point No. 9 of the Guidelines on Performance Criteria with Respect to Foreign Debt (Executive Board Decision No. 6230-(79/140), last amended by Executive Board Decision No. 12274-(00/85), adopted August 24, 2000, but also to commitments contracted or guaranteed by the government for which funds have not been received. It does not apply to government or governmentguaranteed CFAF borrowing from individuals or legal entities that are WAEMU residents. It does not apply either to external loans contracted by the airport project company (AIDB) to finance construction of the new Dakar Airport. The definition of new external debt under the $\mathrm{AC}$ excludes debt rescheduling transactions of debt existing at the time of the approval of the PSI. This criterion is measured on a cumulated basis since the approval of the first program review. The ceiling was raised to CFAF 80 billion in the fourth quarter of 2008 exclusively to finance the toll highway (Dakar-Diamniadio) project. The CFAF 80 billion ceiling will be adjusted downward by the amount of any receipt from a privatization, a sale of a telecommunication license, or any other State asset (such as Sonatel shares) during 2008.

14. For purposes of this assessment criterion, government is understood to include the government as defined in paragraph 3 above, as well as public institutions of an industrial and commercial nature (EPIC), public administrative institutions (EPA), public institutions of a scientific and technical nature, public institutions of a professional nature, public health institutions, local administrations, public enterprises, and government-owned or controlled independent companies (sociétés nationales) (i.e., public enterprises with financial autonomy where the government holds at least 50 percent of the capital), and government agencies. 
15. Any external debt of which the present value, calculated with the reference interest rates mentioned hereafter, is greater than 65 percent of the nominal value (grant element of less than 35 percent) is considered nonconcessional, with the exception of IMF lending under the Poverty Reduction and Growth Facility, which is considered concessional even if it does not meet the 35 percent grant element threshold. For debt with a maturity of more than 15 years, the ten-year reference market interest rate, published by the OECD, is used to calculate the grant element. The six-month reference market rate is used for debt with shorter maturities.

\section{Reporting requirements}

16. The government will report any new external borrowing and its terms to Fund staff as soon as external debt is contracted or guaranteed by the government.

\section{G. Public Sector Contracts Signed by Single Tender}

\section{Definition}

17. Public sector contracts are administrative contracts, drawn up and entered into by government entities subject to the procurement code, for the procurement of supplies, delivery of services, or execution of work. Public sector contracts are considered single-bid contracts when the contracting agent signs the contract with the chosen contractor without competitive tender or award. The quarterly indicative target will apply to public sector contracts examined by the Commission Nationale des Contrats de l'Administration (CNCA) until December 31, 2007, and to those examined by the Direction Centrale des Marchés (DCM) thereafter.

\section{Reporting requirements}

18. The government will report quarterly to the Fund staff, with a lag of no more than one month from the end of the observation period, the total value of contracts signed by all ministries and agencies and the total value of all single-bid contracts signed by these ministries and agencies.

\section{Additional Information for Program Monitoring}

19. The authorities will report to Fund staff the following, with the maximum time lags indicated:

(a) Effective immediately: any decision, circular, edict, decree, ordinance, or law having economic or financial implications for the current program;

(b) With a maximum lag of 45 days, preliminary data on: 
- Tax receipts and tax and customs assessments by categories, accompanied by the corresponding revenue collected by the Treasury on a monthly basis;

- The monthly amount of expenditures committed, certified, and for which payment orders have been issued;

- The quarterly report of the Debt and Investment Directorate (DDI) on execution of investment programs;

- The monthly preliminary government financial operations table (TOFE), based on the Treasury accounts (balances de compte); and

- The provisional balance of the Treasury accounts.

(c) Final data will be provided as soon as the final balances of the treasury accounts are available, but not later than two months after the reporting of provisional data.

20. During the program period, the authorities will report to Fund staff provisional data on a monthly basis on current nonwage non-interest expenditures and domestically financed capital expenditures executed through advance payments and treasury advances, with a lag of no more than 45 days. The data will be drawn from preliminary consolidated treasury account balances. Final data will be provided as soon as the final balances of the treasury accounts are available, but no more than two months after the reporting of provisional data.

21. The government will report to Fund staff:

- The monthly balance sheet of the Central Bank, with a maximum lag of two months;

- The consolidated balance sheet of banks with a maximum lag of two months;

- The monetary survey, on a quarterly basis, with a maximum lag of two months;

- The lending and deposit interest rates of commercial banks, on a monthly basis; and

- Prudential supervision and financial soundness indicators for bank and nonbank financial institutions, as reported in the Table entitled Situation des Etablissements de Crédit vis-à-vis du Dispositif Prudentiel [Survey of Credit Institutions in Relation to the Prudential Framework], on a quarterly basis.

22. The government will update monthly on the website used for this purpose the amount of airport tax — redevance de développement des infrastuctures aéroportuaires (RDIA) collected, deposited in the escrow account, and used for the repayment of the loan financing the construction of the new airport. 
Table 1 of MEFP: Quantitative Assessment Criteria and Indicative Targets for 2008-09 1/

(In billions of CFA francs; unless otherwise specified)

\begin{tabular}{|c|c|c|c|c|}
\hline & \multicolumn{2}{|c|}{ June 30, 2008} & \multirow[t]{2}{*}{ September 30, 2008} & \multirow[t]{2}{*}{ December 31, 2008} \\
\hline & Initial program target & New target & & \\
\hline \multicolumn{5}{|l|}{ Assessment criteria } \\
\hline Floor on the basic fiscal balance $2 /$ & -26 & -48 & -71 & -95 \\
\hline \multicolumn{5}{|l|}{ Ceiling on the contracting or guaranteeing of new } \\
\hline nonconcessional external debt by the government $3 / 4$ / & 0 & 0 & 0 & 80 \\
\hline Ceiling on government domestic payment arrears (stock) $5 /$ & 0 & 0 & 0 & 0 \\
\hline Ceiling on government external payment arrears (stock) $5 /$ & 0 & 0 & 0 & 0 \\
\hline \multicolumn{5}{|l|}{ Ceiling on the amount of the float (depenses liquidees } \\
\hline non payees) $6 /$ & 30 & 50 & 40 & 30 \\
\hline \multicolumn{5}{|l|}{ Indicative target } \\
\hline $\begin{array}{l}\text { Quarterly ceiling on the share of the value of public sector } \\
\text { contracts signed by single tender (in percent) }\end{array}$ & 20 & 20 & 20 & 20 \\
\hline
\end{tabular}

1/ Data for September are indicative targets, with the exception of the assessment criteria monitored on a continuous basis.

2/ Defined as total revenue minus total expenditure and net lending, excluding externally financed capital expenditure, on-lending,

and HIPC and MDRI spending. Cumulative since the beginning of the year. Total revenue excludes

privatization receipts and sales of mobile telephone licenses.

$3 /$ This target, which was defined on a continuous basis, is now defined on a cumulative basis since the approval of the first program review. The ceiling was raised to CFAF 80 bn in the 4th quarter 2008, to finance exclusively the Dakar-Diamniadio toll highway project. The CFAF 80 billion ceiling will be adjusted

downward by the amount of any receipt from a privatization, a sale of a telecommunication license, or any other State asset (such as Sonatel shares) during 2008.

4/ This criterion excludes government or government-guaranteed CFAF borrowing from financial institutions within WAEMU. It also

excludes external loans contracted by the airport project company (AIDB) to finance the construction of the new Dakar Airport.

$5 /$ Monitored on a continuous basis.

6/ The budgetary float, which was defined as the expenditure for which a payment order has been issued and which has not been paid, is now defined as

the expenditure for which a bill has been received and recognized (depense liquidee) and which has not been paid. 
Table 2 of MEFP. Structural Conditionality, 2008-09

Policy Measures

Prior Action

1. Publish administrative orders from the prime minister and finance minister which will limit the authorizations for commitments on current expenditure and domestically-financed capital expenditure, as specified in paragraph 10 .

\section{Structural Assessment Criteria}

2. Adopt and make effective the new tariff structure for electricity, which provides progressive tariff rates, in order to encourage energy savings, with lower tariff adjustments for low-income consumers.

3. Issue the implementation decree for the application of Law 2007-16 on DISEZ, as specified in paragraph 17 of the MEFP.

4. Publish an administrative order from the prime minister with guidelines to strengthen public investment planning and evaluation, as specified in paragraph 16 of the MEFP.

5. Develop a rolling two-year program of issuance of government securities, in collaboration with the $\mathrm{BCEAO}$, as specified in paragraph 13 of the MEFP.

6. Complete a comprehensive audit of payment delays by the financial audit inspectorate of the MEF (Inspection Générale des Finances), as specified in paragraph 14 of the MEFP.
November 15, 2008

November 15, 2008

Limit the impact of the special economic zone on government revenues and preserve macroeconomic stability.

Encourage the selection of the most economically and socially profitable investment projects; improve public expenditure productivity and the growth potential of the economy.

June 30, 2008

Manage electricity demand to oil prices on the fiscal and external accounts. Protect the poorest households from increases in international prices.

Improve cash-flow management and avoid payment delays; improve debt management and facilitate financial market development; support BCEAO's monetary policy.

Eliminate payment delays, reestablish budgetary framework integrity, and

September 30, 2008 underpin the development of the private sector and the soundness of the financial sector. limit the impact of international 


\begin{tabular}{lll}
\hline \multicolumn{1}{c}{ Policy Measures } & $\begin{array}{l}\text { Target Date for } \\
\text { Implementation }\end{array}$ & Macroeconomic Rationale \\
\hline $\begin{array}{l}\text { 7. Adopt all the legal texts and regulations allowing } \\
\text { the effective transfer of direct State tax collection } \\
\text { responsibilities from the Treasury to the DGID } \\
\text { effective January 1, 2009, as specified in paragraph } \\
23 \text { of the MEFP. }\end{array}$ & $\begin{array}{l}\text { October 31, 2008 } \\
\text { Improve tax collections and } \\
\text { enhance fiscal sustainability, by } \\
\text { facilitating the fight against tax } \\
\text { fraud. }\end{array}$ \\
$\begin{array}{l}\text { 8. Prepare memoranda of understanding which } \\
\text { stipulate the respective rights and responsibilities of } \\
\text { APIX, DGID, and DDI regarding the management of } \\
\text { DISEZ, as specified in paragraph 17 of the MEFP. }\end{array}$ & March 31, 2009 & $\begin{array}{l}\text { Preserve tax revenues and } \\
\text { safeguard fiscal governance } \\
\text { and macroeconomic stability. }\end{array}$ \\
\hline
\end{tabular}


INTERNATIONAL MONETARY FUND

AND

INTERNATIONAL DEVELOPMENT ASSOCIATION

\section{SENEGAL}

\section{Joint IMF/IDA Debt Sustainability Analysis}

Prepared by the Staffs of the International Monetary Fund and the

International Development Association

Approved by Sharmini Coorey and Adnan Mazarei (IMF)

and Sudhir Shetty and Carlos Braga (World Bank)

May 30, 2008

The 2008 debt sustainability analysis (DSA) indicates that Senegal is at a low risk of debt distress. ${ }^{I}$ External debt ratios have improved substantially over the past few years thanks to HIPC and MDRI debt relief while domestic debt ratios have traditionally been low, and debt dynamics under the baseline scenario are projected to remain favorable.

\section{BACKGROUND}

1. Senegal's external debt sustainability indicators improved substantially after the enhanced HIPC Initiative and the Multilateral Debt Relief Initiative (MDRI). Senegal reached its HIPC completion point in April 2004, when it received debt relief of about US $\$ 850$ million in nominal terms. ${ }^{2}$ In 2005, Senegal qualified for further debt relief under the MDRI when the IMF, the International Development Association (IDA) and the African Development Fund (AfDF) cancelled their claims on Senegal amounting to about US $\$ 1.4$ billion in nominal terms. ${ }^{3}$ As a result of these two initiatives, the NPV of external public and publicly guaranteed (PPG) debt outstanding has been substantially reduced from 33.1 percent of GDP at end-2005 to an estimated 18.3 percent of GDP at end-2007.

\footnotetext{
${ }^{1}$ The DSA has been prepared jointly by World Bank and IMF staffs. The fiscal year for Senegal is January 1 to December 31.

2 See Senegal: Enhanced Initiative for HIPC-Completion Point Document (Country Report 04/130 or IDA/R2004-0065).

${ }^{3}$ MDRI debt relief from the IMF became effective January 5, 2006, providing stock relief on debt disbursed before end-2004 and still outstanding at end-2005. IDA and the AfDF started providing debt relief in July 2006. The eligible debt covers IDA credits disbursed before end-2003 and AfDF credits disbursed before end-2004 that were still outstanding at the time of qualification.
} 
2. Nominal external debt amounted to US\$4.5 billion (18.1 percent of GDP) at end2007, of which the World Bank and AfDB held 44 percent and Paris Club creditors held 6 percent. Since the last DSA (completed in January 2007), the Islamic Development Bank and China have granted debt relief to Senegal and only ECOWAS and Sweden have yet to provide HIPC assistance.

3. Senegal's public domestic debt remains low. ${ }^{4}$ The NPV of public domestic debt is estimated at 5.6 percent of GDP at end-2007, or one-fourth of total debt. The majority of this debt is non-concessional, denominated in local currency, and held by WAEMU banks. The recent reforms of the regional financial market and ample bank liquidity have allowed Senegal (and other WAEMU member countries) to increasingly place debt instruments, including of longer maturity. In 2007, Senegal issued CFAF 113 billion (2 percent of GDP) in two tranches, at 5.5 percent interest, over five and ten years.

4. Private sector exposure also appears limited once the sector's sizable assets are considered. The International Investment Position compiled by the BCEAO for end-2006 indicates that the stock of private external debt is 22 percent of GDP, three quarters of which consist of trade credits. The remainder is primarily loans taken abroad and currency and deposits owed by Senegalese banks to nonresidents. Private sector external assets amounting to 13 percent of GDP may, depending on their disposition to service debt, also help limit private sector exposure. Nonetheless, given its importance in overall external debt sustainability, the future evolution of the private sector debt should be closely monitored.

\section{UNDERLYING DSA ASSUMPTIONS}

\section{The macroeconomic framework underlying the DSA is based on the} implementation of sound macroeconomic and structural policies, and external financing mainly through grants, highly concessional loans, and significant FDI. Box 1 summarizes the key macroeconomic assumptions. Growth projections, broadly in line with the baseline scenario of the PRSP II, average 51/2 percent over 2008-28. This reflects the authorities' intention to raise the growth potential of the economy by increasing capital and labor utilization and spur productivity growth. In addition to pursuing sound macroeconomic policies, this would be achieved through reform efforts to improve the business environment, diversify exports, develop infrastructure, make the provision of energy more reliable, and reform the labor market. Grants and loans from donors are expected to remain significant. FDI related to a number of well-defined projects is expected to pick up considerably and should help sustain long-term growth. While FDI inflows will lead to higher imports and a temporary increase in the current account deficit in the short run, these should subside over the medium to long run as the FDI-related export production grows. With a primary fiscal

\footnotetext{
${ }^{4}$ Public domestic debt comprises central government debt. Debt issued in the WAEMU is included in domestic debt.
} 
deficit declining from around 3 percent of GDP to 2 percent of GDP, external borrowing on concessional terms will remain around 2 percent of GDP, with an average grant element of 39 percent. Any additional financing needs will be covered domestically, primarily through bond issues in the regional financial markets.

6. The underlying DSA assumptions differ from the previous DSA. Differences arise as medium-term assumptions have been modified to reflect new information on commodity prices, as well as potential and realized increased FDI commitments and a concomitant projected improved performance of exports. Export performance is initially worse than in the previous DSA, reflecting persistent difficulties in the groundnut and fishing sectors and a slower recovery of the phosphate processor ICS. After 2013, FDI-related export production propels export growth to higher levels than previously assumed. Imports are assumed to be higher than in the past. Initially, this reflects higher oil prices and construction and services created by FDI. In later years, reforms lead to faster growth in secondary and tertiary sectors than in the past, resulting in increased imports. Consequently, the medium-run current account deficit is assumed to be higher than in past projections, while the long-run current account deficit fares much better than previously, as export growth begins to outpace import growth. Finally, reflecting the government's renewed commitment to macroeconomic stability under the PSI, the long-run primary fiscal deficit is assumed to improve moderately relative to previous projections. 


\section{Box 1. Macroeconomic Assumptions Underlying the DSA}

The macroeconomic assumptions over the period 2008-28 are as follows:

Real GDP growth will average 51/2 percent.

Inflation, as measured by the GDP deflator, is expected to return, over the medium term, to its historical level of just above two percent.

The noninterest current account deficit (including grants) initially widens to about 11 percent of GDP in 2008-13. Export growth is projected to average 12/2 percent during the period - helped by a gradual recovery in traditional exports, especially of phosphate products - but lags the rapid growth of imports related to the large FDI projects and increased oil prices. Over 2014-28, once FDI-related exports (rising by 10.8 percent) begin to outpace import growth (rising by 9 percent), the current account deficit could decline to about 7 percent of GDP by 2028. Net FDI is expected to hover at around 6 percent of GDP over the medium to long term.

The primary fiscal deficit will gradually decline from just above 3 percent of GDP in 2007 to just under 2 percent of GDP in 2028, reflecting increased revenues and improved public expenditure management - a reform focus under the PSI.

Net aid flows (grants and concessional loans) gradually decline from 7 percent of GDP in 2008 to $3 \frac{1}{2}$ percent of GDP in 2028 . Averaging 50 percent of total aid flows, concessional loans are assumed to be on standard terms. For example, new IDA borrowing (averaging almost 60 percent of new borrowing) is assumed to have a 0.75 percent interest rate, 10 -year grace period, and 40 -year maturity.

Public sector domestic borrowing will remain under 40 percent of overall public sector borrowing (based on NPV of debt calculations). Commercial bank holdings of Senegalese treasury bills and bonds remain the primary source of domestic public credit, with an assumed 5 $1 / 2$ percent interest rate and maturities ranging from one to ten years.

Nonconcessional borrowing is assumed to remain the exception. The DSA incorporates the borrowing related to the Dakar-Diamniado toll road, at CFAF 40 billion (0.7 percent of GDP) each in 2008 and 2009. According to staff's analysis, the project's expected return exceeds the anticipated costs associated with the non-concessional funds. Alternative donor financing for this project is not in sight, and raising funds of this magnitude in the WAEMU market would exceed that market's capacity. The incorporation of this non-concessional borrowing is in line with the government's commitment to consult with IMF staff (as specified in the PSI) and with Bank staff well in advance for any exceptions that may possibly be needed, for projects for which concessional financing cannot be obtained and a public private partnership (PPP) cannot be negotiated. 


\section{EXTERNAL DSA}

7. Under the baseline scenario, all PPG external debt indicators remain relatively stable over time and well below the policy-dependent debt burden thresholds. ${ }^{5} \mathrm{~A}$ marginal rise in some debt indicators is noticeable initially, reflecting growth in the NPV of multilateral debt, before they assume a slight downward trend over time. The decline is most pronounced in the NPV of the debt-to-exports ratio, as export growth outpaces debt growth. The debt service ratios remain relatively stable and far below thresholds, with both the debtservice-to exports and debt-service-to-revenue ratio hovering around 5 percent (Figure 1, Table 1).

\section{Debt indicators in the baseline initially are higher than under the historical} scenario, and later fall below the historical scenario. Initially, higher debt-creating flows resulting from a higher medium-term current account deficit in the baseline, push the projected debt path above the historical path. ${ }^{6}$ The medium-term current account deficit in the baseline is more than double that assumed in the historical scenario, which is based on the average current account deficit over the past ten years (Figure 1, Table 2). In the long run, the baseline assumes higher FDI flows than in the historical scenario. Lacking substantial FDI to offset the current account deficit, the historical scenario accumulates debt-creating flows.

\section{The standard stress tests do not reveal any serious vulnerabilities, as all ratios} are below the thresholds. The most extreme stress test for Senegal's NPV of debt relative to GDP and revenue is a temporary reduction in nondebt creating flows such as transfers and FDI in 2009-10 (relative to the historical average). Debt and debt service both rise sharply after the shock but remain below the thresholds during the projection period. A combination of reduced nondebt creating flows and lower GDP and export growth is the most extreme stress test for the NPV of debt-to-exports. In this case, the NPV of debt-to-exports rises considerably, but it remains below the threshold (Figure 1, Table 2).

10. An alternative stress test was calculated by applying a sudden decline in FDI; as with the other stress tests, debt levels remained below thresholds. Although the sizeable medium-term FDI growth is based on well-defined projects and FDI flows are generally

\footnotetext{
${ }^{5}$ The quality of policies and institutions is measured by the World Bank's Country Policy and Institutional Assessment (CPIA). An average of the most recent three-years' ratings is applied in the analysis. The indicative external debt burden thresholds for Senegal are: (i) an NPV of external PPG debt-to-GDP ratio of 40 percent; (ii) an NPV of external PPG debt-to-exports ratio of 150 percent; (iii) an NPV of external PPG debt-to-revenue ratio of 250 percent; (iv) an external PPG debt service-to-exports ratio of 20 percent; and (v) an external medium- and long-term PPG debt service-to-revenue ratio of 30 percent.

${ }^{6}$ Much of the projected current account deficit is financed through FDI inflows. However, non-FDI factors such as weak export growth and higher oil prices create a balance of payments gap, which is assumed to be financed by both public and private sector borrowing.
} 
more stable than portfolio flows, there is always the possibility that FDI flows decline drastically. This may occur as a result of a number of exogenous factors, such as the political environment in either Senegal or the FDI-originating country. Even in the extreme scenario that FDI comes to a complete halt in the two years where it is currently projected to be largest (i.e., 2009-10), Senegal's debt ratios would remain within the indicative thresholds (Table 2).

\section{Public DSA}

11. The baseline scenario, consistent with the external DSA, entails a gradual rise in debt indicators. The NPV of debt-to-GDP (debt-to-revenue) reaches a plateau at 30 percent (135 percent). The relatively smooth path reflects a gradually declining fiscal deficit. The non-concessional domestically issued debt and the assumed temporary reliance on nonconcessional external borrowing in 2008 and 2009 do not significantly impact public debt sustainability. The debt service-to-revenue ratio is also relatively low, ranging between 6 and 9 percent (Figure 2, Table 3).

12. Notwithstanding the manageable outlook in the baseline scenario, public debt sustainability hinges on containing the fiscal deficit. If the fiscal deficit remains at the 2008 level of 5 percent of GDP (equivalent to a primary deficit of 4.2 percent of GDP) over the entire projection period, the NPV of debt-to-GDP ratio will increase by approximately 2 percent per year, from almost 25 percent in 2008 to 60 percent in 2028 . The financing needs created by the accumulated deficits would risk crowding out the private sector. The NPV of debt-to-revenue and debt service indicators paint a similar picture, reinforcing the need for the prudent fiscal policy that is currently envisioned in the baseline (Figure 2, Table 4).

13. The public debt position remains vulnerable to unexpected shocks. The second most extreme stress test - a reduction in 2009 and 2010 real GDP growth by 2 percentage points per annum (one standard deviation below past ten years average real GDP growth) would raise the NPV of debt-to-GDP ratio to close to 60 percent by 2028. The NPV of debtto-revenue and debt service indicators would follow a similar upward trajectory. Given that Senegal's economy is prey to large fluctuations in real GDP growth, a cautious approach to fiscal policy would thus be advisable. ${ }^{7}$

\section{Conclusion}

14. In sum, based on the staff's analysis, Senegal's external debt burden is subject to a low risk of debt distress. In addition, the public DSA suggests that Senegal's overall risk of debt distress remains low even after considering domestic debt in the analysis. The

\footnotetext{
${ }^{7}$ Senegal's real GDP growth dropped by almost 3 percentage points in 2006 (from 5.3 percent in 2005 to 2.3 percent in 2006), mainly due to difficulties faced by ICS.
} 
baseline projections and the associated standard stress tests show low risk related to external debt, as all of the indicators remain well below the indicative debt burden thresholds.

However, public debt sustainability is vulnerable to increased fiscal deficits (exceeding 4 percent) and negative shocks to real GDP growth. Consequently, Senegal would benefit from continued fiscal discipline, prudent non-concessional borrowing, and sensible debt management. 
Figure 1. Senegal: Updated DSA--Indicators of Public and Publicly Guaranteed External Debt Under Alternative Scenarios, 2008-28

Senegal's PPG external debt ratios remain well below the policy dependent threshold under both the baselin and the most extreme stress test.
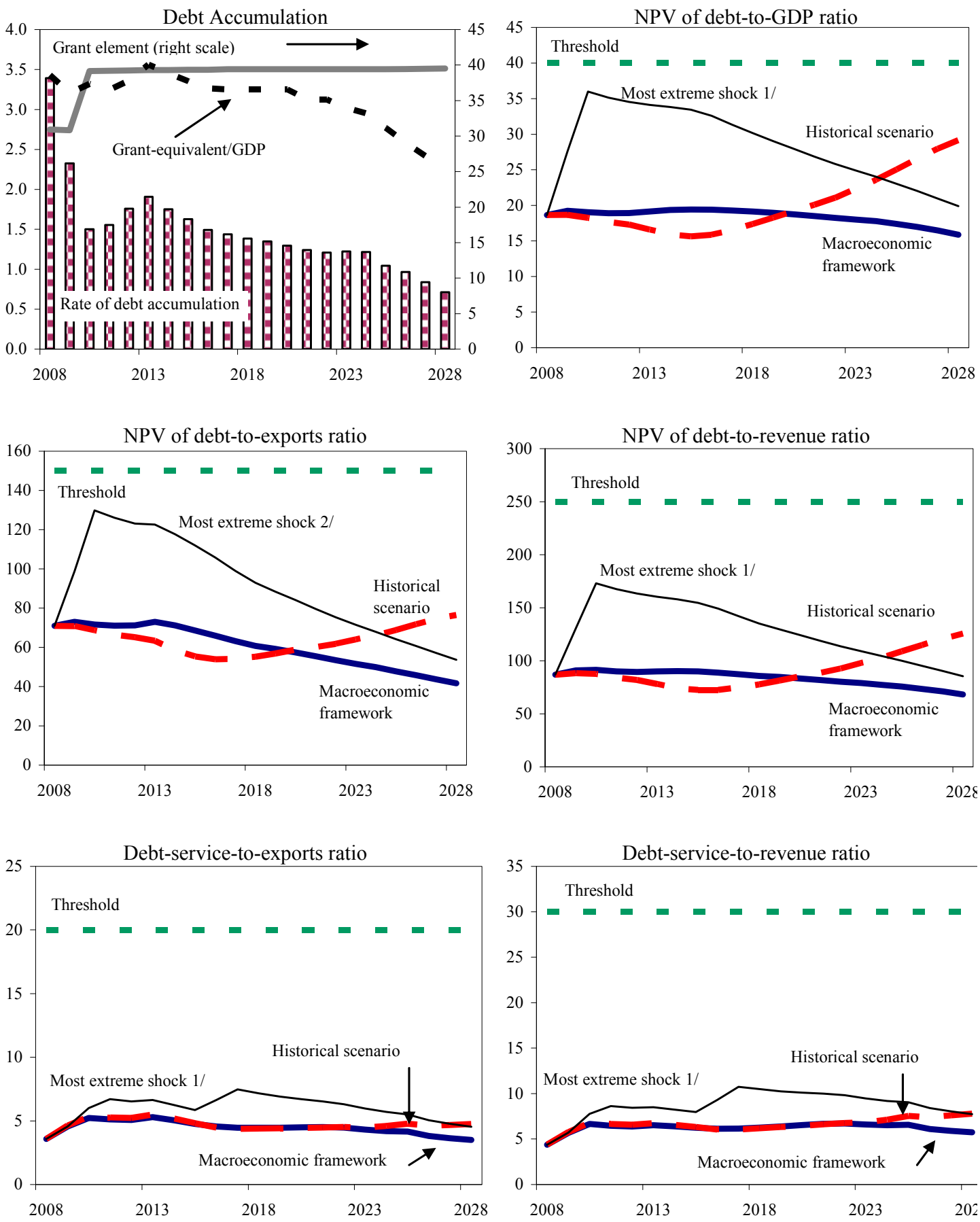

Source: Staff projections and simulations.

1/ Non-debt creating flows at historical average minus one standard deviation in 2009-10.

2/ Combination of one-half standard deviation shocks to historical averages of real GDP growth, export growth, GDP deflator, and non-debt creating flows in 2009-10. 
Figure 2. Senegal: Updated DSA--Indicators of Public Debt Under Alternative Scenarios, 2008-2028 Senegal's public debt sustainability hinges on containing the fiscal deficit within 4 percent of GDP over the long term, as assumed under the macroeconomic framework.
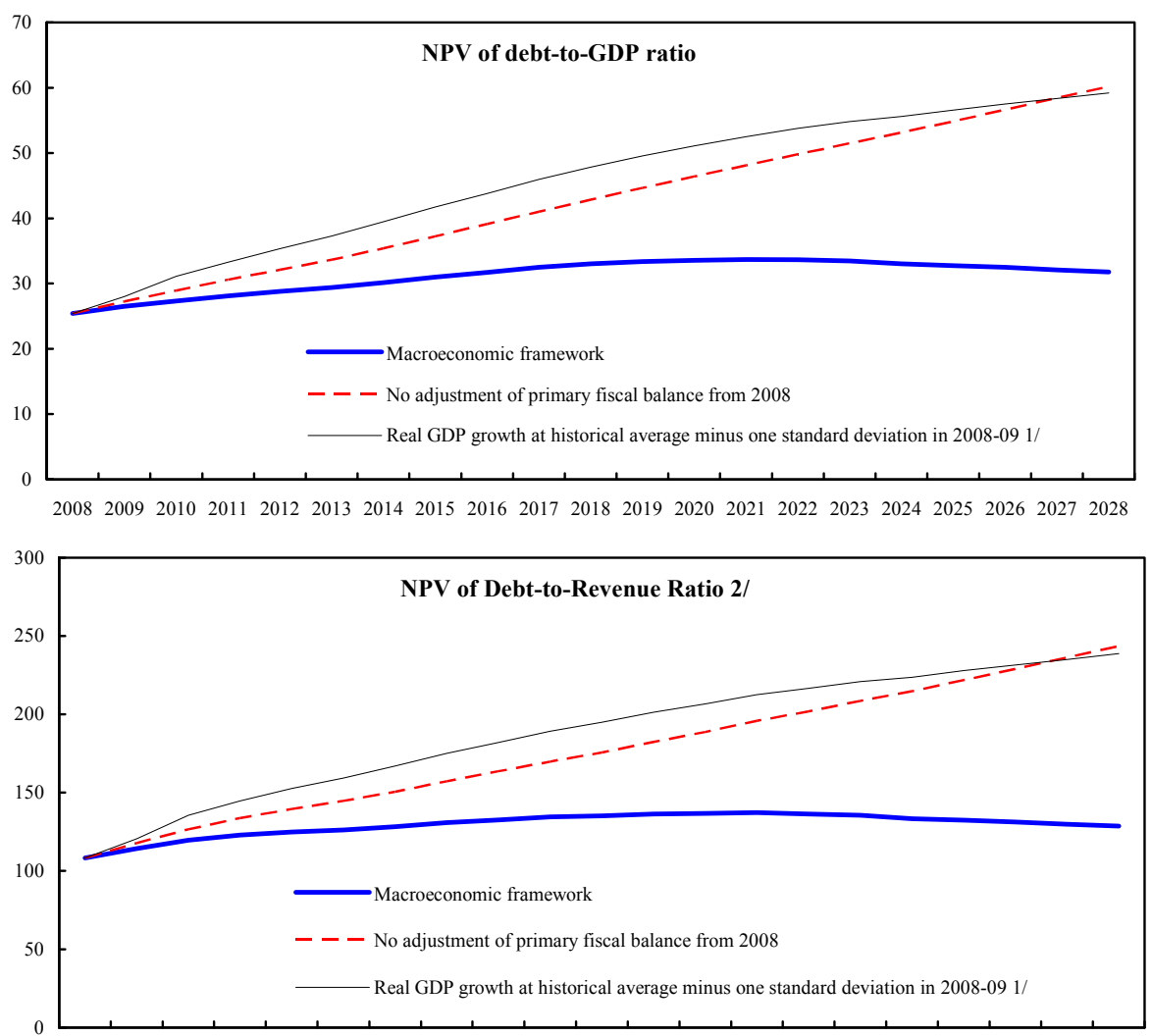

200820092010201120122013201420152016201720182019202020212022202320242025202620272028

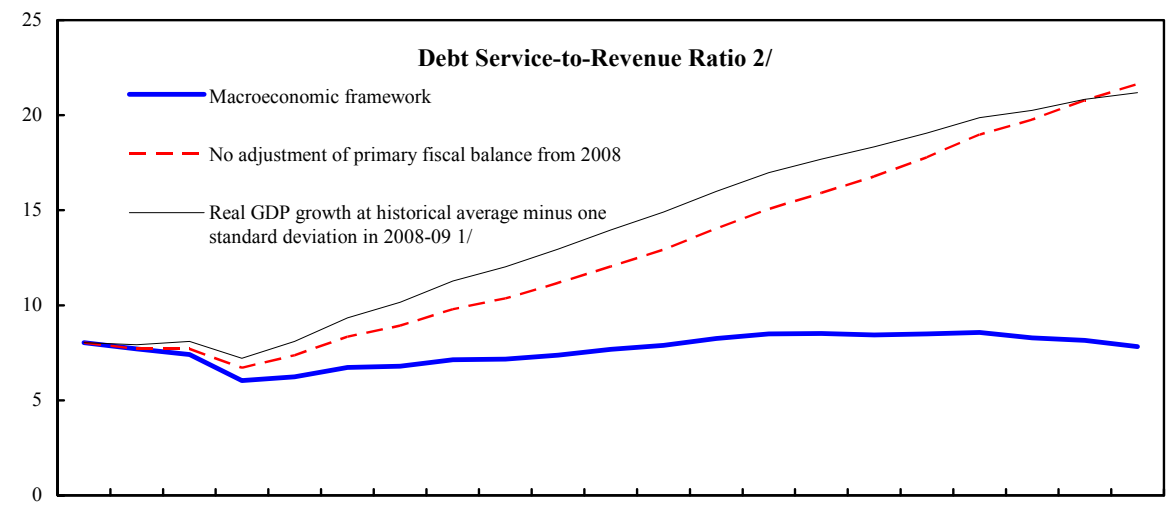

200820092010201120122013201420152016201720182019202020212022202320242025202620272028

Source: Staff projections and simulations.

1/ Corresponds to the most extreme stress test, defined as the test that yields the highest debt ratio in 2018.

2/ Revenue including grants. 


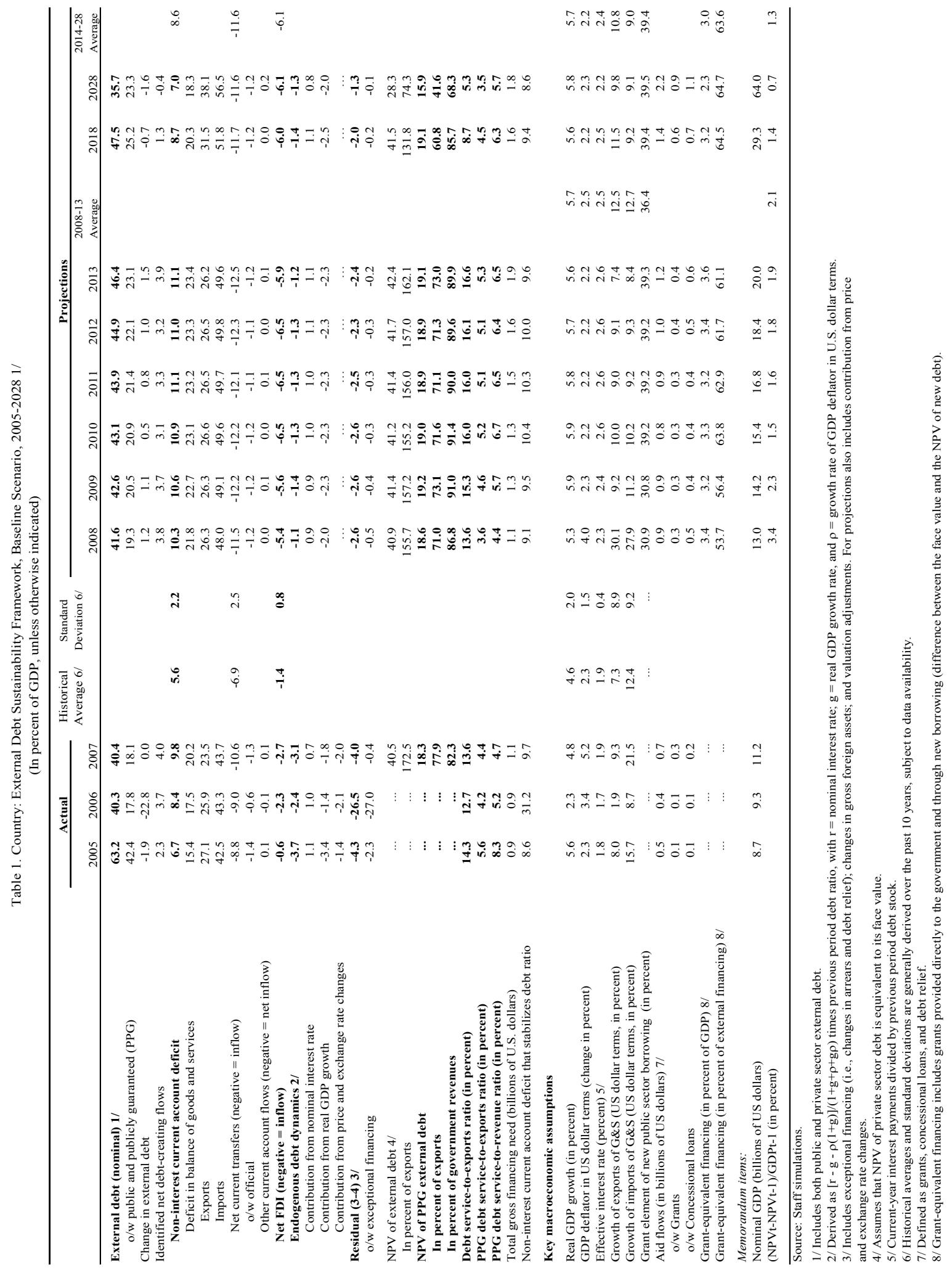


Table 2. Country: Sensitivity Analyses for Key Indicators of Public and Publicly Guaranteed External Debt, 2008-28 (In percent)

\begin{tabular}{|c|c|c|c|c|c|c|c|c|}
\hline & \multicolumn{8}{|c|}{ Projections } \\
\hline & 2008 & 2009 & 2010 & 2011 & 2012 & 2013 & 2018 & 2028 \\
\hline \multicolumn{9}{|c|}{ NPV of debt-to-GDP ratio } \\
\hline Baseline & 19 & 19 & 19 & 19 & 19 & 19 & 19 & 16 \\
\hline \multicolumn{9}{|l|}{ A. Alternative Scenarios } \\
\hline A1. Key variables at their historical averages in 2009-28 1/ & 19 & 19 & 18 & 18 & 17 & 17 & 17 & 29 \\
\hline A2. New public sector loans on less favorable terms in $2009-28$ 2/ & 19 & 20 & 21 & 22 & 23 & 24 & 26 & 27 \\
\hline \multicolumn{9}{|l|}{ B. Bound Tests } \\
\hline B1. Real GDP growth at historical average minus one standard deviation in 2009-10 & 19 & 20 & 20 & 20 & 20 & 20 & 20 & 17 \\
\hline B2. Export value growth at historical average minus one standard deviation in 2009-10 3/ & 19 & 21 & 24 & 23 & 23 & 23 & 22 & 17 \\
\hline B3. US dollar GDP deflator at historical average minus one standard deviation in 2009-10 & 19 & 20 & 20 & 19 & 19 & 19 & 20 & 17 \\
\hline B4. Net non-debt creating flows at historical average minus one standard deviation in 2009-10 4/ & 19 & 28 & 36 & 35 & 35 & 34 & 30 & 20 \\
\hline B5. Combination of B1-B4 using one-half standard deviation shocks & 19 & 25 & 33 & 32 & 31 & 31 & 28 & 20 \\
\hline B6. One-time 30 percent nominal depreciation relative to the baseline in 20095 / & 19 & 27 & 27 & 27 & 27 & 27 & 27 & 23 \\
\hline B7. Sudden stop in FDI 2009-10 6/ & 19 & 23 & 27 & 26 & 26 & 26 & 24 & 18 \\
\hline \multicolumn{9}{|c|}{ NPV of debt-to-exports ratio } \\
\hline Baseline & 71 & 73 & 72 & 71 & 71 & 73 & 61 & 42 \\
\hline \multicolumn{9}{|l|}{ A. Alternative Scenarios } \\
\hline A1. Key variables at their historical averages in 2009-28 1/ & 71 & 71 & 69 & 67 & 65 & 63 & 55 & 77 \\
\hline A2. New public sector loans on less favorable terms in $2009-282 /$ & 71 & 77 & 79 & 82 & 85 & 91 & 84 & 70 \\
\hline \multicolumn{9}{|l|}{ B. Bound Tests } \\
\hline B1. Real GDP growth at historical average minus one standard deviation in 2009-10 & 71 & 73 & 71 & 69 & 69 & 69 & 58 & 41 \\
\hline B2. Export value growth at historical average minus one standard deviation in 2009-10 3/ & 71 & 87 & 109 & 106 & 104 & 104 & 82 & 53 \\
\hline B3. US dollar GDP deflator at historical average minus one standard deviation in $2009-10$ & 71 & 73 & 71 & 69 & 69 & 69 & 58 & 41 \\
\hline B4. Net non-debt creating flows at historical average minus one standard deviation in 2009-10 4/ & 71 & 104 & 134 & 130 & 126 & 125 & 92 & 50 \\
\hline B5. Combination of B1-B4 using one-half standard deviation shocks & 71 & 99 & 130 & 126 & 123 & 123 & 93 & 54 \\
\hline B6. One-time 30 percent nominal depreciation relative to the baseline in 20095 / & 71 & 73 & 71 & 69 & 69 & 69 & 58 & 41 \\
\hline B7. Sudden stop in FDI 2009-10 6/ & 71 & 87 & 100 & 97 & 95 & 95 & 74 & 45 \\
\hline \multicolumn{9}{|c|}{ NPV of debt-to-revenue ratio } \\
\hline Baseline & 87 & 91 & 91 & 90 & 90 & 90 & 86 & 68 \\
\hline \multicolumn{9}{|l|}{ A. Alternative Scenarios } \\
\hline A1. Key variables at their historical averages in 2009-28 1/ & 87 & 88 & 88 & 84 & 82 & 78 & 78 & 125 \\
\hline A2. New public sector loans on less favorable terms in 2009-28 2/ & 87 & 96 & 101 & 103 & 107 & 112 & 118 & 114 \\
\hline \multicolumn{9}{|l|}{ B. Bound Tests } \\
\hline B1. Real GDP growth at historical average minus one standard deviation in 2009-10 & 87 & 94 & 97 & 95 & 94 & 95 & 91 & 74 \\
\hline B2. Export value growth at historical average minus one standard deviation in 2009-10 3/ & 87 & 99 & 114 & 111 & 109 & 108 & 97 & 72 \\
\hline B3. US dollar GDP deflator at historical average minus one standard deviation in 2009-10 & 87 & 92 & 94 & 92 & 91 & 91 & 88 & 72 \\
\hline B4. Net non-debt creating flows at historical average minus one standard deviation in 2009-10 4/ & 87 & 130 & 173 & 168 & 163 & 160 & 135 & 85 \\
\hline B5. Combination of B1-B4 using one-half standard deviation shocks & 87 & 120 & 157 & 152 & 149 & 147 & 127 & 86 \\
\hline B6. One-time 30 percent nominal depreciation relative to the baseline in 20095 / & 87 & 129 & 129 & 126 & 125 & 126 & 121 & 99 \\
\hline B7. Sudden stop in FDI 2009-10 6/ & 87 & 108 & 129 & 125 & 123 & 122 & 108 & 77 \\
\hline
\end{tabular}


Table 2. Country: Sensitivity Analyses for Key Indicators of Public and Publicly Guaranteed External Debt, 2008-28 (continued) (In percent)

Debt service-to-exports ratio

\begin{tabular}{|c|c|c|c|c|c|c|c|c|}
\hline & \multicolumn{8}{|c|}{ Projections } \\
\hline & 2008 & 2009 & 2010 & 2011 & 2012 & 2013 & 2018 & 2028 \\
\hline Baseline & 4 & 5 & 5 & 5 & 5 & 5 & 4 & 3 \\
\hline \multicolumn{9}{|l|}{ A. Alternative Scenarios } \\
\hline A1. Key variables at their historical averages in 2009-28 1/ & 4 & 5 & 5 & 5 & 5 & 5 & 4 & 5 \\
\hline A2. New public sector loans on less favorable terms in $2009-28$ 2/ & 4 & 5 & 4 & 4 & 5 & 5 & 5 & 5 \\
\hline \multicolumn{9}{|l|}{ B. Bound Tests } \\
\hline B1. Real GDP growth at historical average minus one standard deviation in 2009-10 & 4 & 5 & 5 & 5 & 5 & 5 & 4 & 3 \\
\hline B2. Export value growth at historical average minus one standard deviation in 2009-10 3/ & 4 & 5 & 7 & 7 & 7 & 7 & 6 & 5 \\
\hline B3. US dollar GDP deflator at historical average minus one standard deviation in 2009-10 & 4 & 5 & 5 & 5 & 5 & 5 & 4 & 3 \\
\hline B4. Net non-debt creating flows at historical average minus one standard deviation in 2009-10 4/ & 4 & 5 & 6 & 7 & 7 & 7 & 7 & 5 \\
\hline B5. Combination of B1-B4 using one-half standard deviation shocks & 4 & 5 & 6 & 7 & 7 & 7 & 7 & 5 \\
\hline B6. One-time 30 percent nominal depreciation relative to the baseline in 20095 / & 4 & 5 & 5 & 5 & 5 & 5 & 4 & 3 \\
\hline B7. Sudden stop in FDI 2009-10 6/ & 4 & 5 & 6 & 6 & 6 & 6 & 6 & 4 \\
\hline \multicolumn{9}{|c|}{ Debt service-to-revenue ratio } \\
\hline Baseline & 4 & 6 & 7 & 6 & 6 & 7 & 6 & 6 \\
\hline \multicolumn{9}{|l|}{ A. Alternative Scenarios } \\
\hline A1. Key variables at their historical averages in 2009-28 1/ & 4 & 6 & 7 & 7 & 7 & 7 & 6 & 8 \\
\hline A2. New public sector loans on less favorable terms in 2009-28 2/ & 4 & 6 & 5 & 6 & 6 & 6 & 7 & 8 \\
\hline \multicolumn{9}{|l|}{ B. Bound Tests } \\
\hline B1. Real GDP growth at historical average minus one standard deviation in 2009-10 & 4 & 6 & 7 & 7 & 7 & 7 & 7 & 6 \\
\hline B2. Export value growth at historical average minus one standard deviation in 2009-10 3/ & 4 & 6 & 7 & 7 & 7 & 7 & 7 & 6 \\
\hline B3. US dollar GDP deflator at historical average minus one standard deviation in 2009-10 & 4 & 6 & 7 & 7 & 7 & 7 & 7 & 6 \\
\hline B4. Net non-debt creating flows at historical average minus one standard deviation in 2009-10 4/ & 4 & 6 & 8 & 9 & 8 & 8 & 10 & 8 \\
\hline B5. Combination of B1-B4 using one-half standard deviation shocks & 4 & 6 & 8 & 8 & 8 & 8 & 10 & 8 \\
\hline B6. One-time 30 percent nominal depreciation relative to the baseline in 20095 / & 4 & 8 & 10 & 9 & 9 & 9 & 9 & 8 \\
\hline B7. Sudden stop in FDI 2009-10 6/ & 4 & 6 & 7 & 8 & 7 & 8 & 8 & 7 \\
\hline \multicolumn{9}{|l|}{ Memorandum item: } \\
\hline Grant element assumed on residual financing (i.e., financing required above baseline) $7 /$ & 35 & 35 & 35 & 35 & 35 & 35 & 35 & 35 \\
\hline
\end{tabular}

Source: Staff projections and simulations.

1/ Variables include real GDP growth, growth of GDP deflator (in U.S. dollar terms), non-interest current account in percent of GDP, and non-debt creating flows.

2/ Assumes that the interest rate on new borrowing is by 2 percentage points higher than in the baseline., while grace and maturity periods are the same as in the baseline.

3/ Exports values are assumed to remain permanently at the lower level, but the current account as a share of GDP is assumed to return to its baseline level after the shock (implicitly assuming an offsetting adjustment in import levels).

4/ Includes official and private transfers and FDI

5/ Depreciation is defined as percentage decline in dollar/local currency rate, such that it never exceeds 100 percent.

6/ Assumes no FDI flows in 2009-10.

7/ Applies to all stress scenarios except for A2 (less favorable financing) in which the terms on all new financing are as specified in footnote 2. 


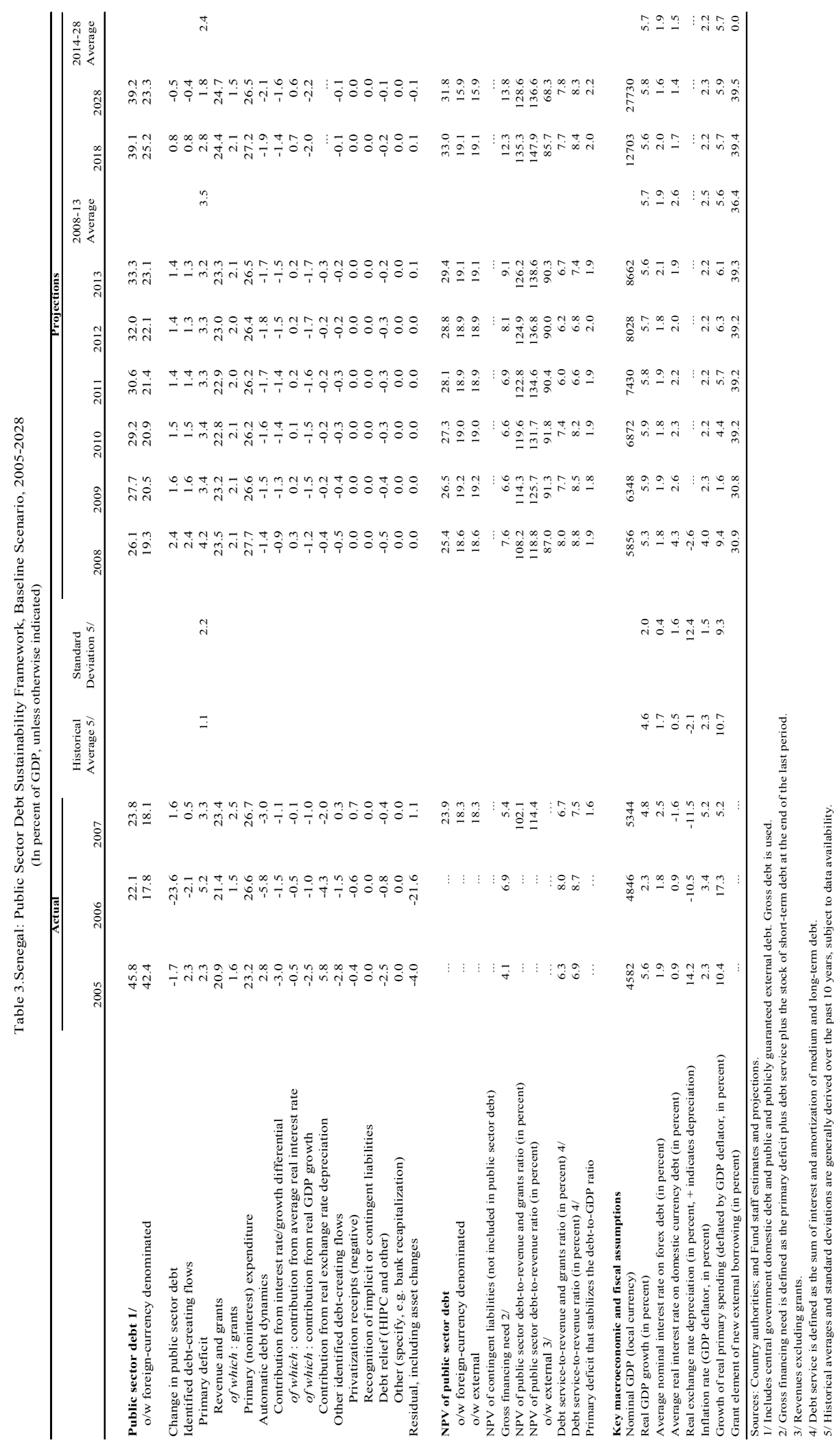


Table 4.Senegal: Sensitivity Analysis for Key Indicators of Public Debt 2008-2028

\begin{tabular}{|c|c|c|c|c|c|c|c|c|}
\hline & \multicolumn{8}{|c|}{ Projections } \\
\hline & 2008 & 2009 & 2010 & 2011 & 2012 & 2013 & 2018 & 2028 \\
\hline \multicolumn{9}{|c|}{ NPV of Debt-to-GDP Ratio } \\
\hline Baseline & 25 & 26 & 27 & 28 & 29 & 29 & 33 & 32 \\
\hline \multicolumn{9}{|l|}{ A. Alternative scenarios } \\
\hline Primary balance is unchanged from 2008 & 25 & 27 & 29 & 31 & 32 & 34 & 43 & 60 \\
\hline Permanently lower GDP growth 1/ & 25 & 27 & 28 & 29 & 30 & 31 & 39 & 54 \\
\hline \multicolumn{9}{|l|}{ B. Bound tests } \\
\hline B1. Real GDP growth is at historical average minus one standard deviations in 2009-2010 & 25 & 28 & 31 & 33 & 35 & 37 & 48 & 59 \\
\hline B2. Primary balance is at historical average minus one standard deviations in $2009-2010$ & 25 & 26 & 27 & 28 & 28 & 29 & 33 & 32 \\
\hline B3. Combination of B1-B2 using one half standard deviation shocks & 25 & 26 & 26 & 26 & 27 & 27 & 30 & 28 \\
\hline B4. One-time 30 percent real depreciation in 2009 & 25 & 34 & 34 & 34 & 34 & 34 & 36 & 33 \\
\hline B5. 10 percent of GDP increase in other debt-creating flows in 2009 & 25 & 36 & 37 & 38 & 38 & 39 & 42 & 40 \\
\hline \multicolumn{9}{|c|}{ NPV of Debt-to-Revenue Ratio 2/ } \\
\hline Baseline & 108 & 114 & 120 & 123 & 125 & 126 & 135 & 129 \\
\hline \multicolumn{9}{|l|}{ A. Alternative scenarios } \\
\hline Primary balance is unchanged from 2008 & 108 & 118 & 127 & 134 & 139 & 145 & 176 & 244 \\
\hline Permanently lower GDP growth $1 /$ & 108 & 115 & 122 & 126 & 131 & 134 & 161 & 217 \\
\hline \multicolumn{9}{|l|}{ B. Bound tests } \\
\hline B1. Real GDP growth is at historical average minus one standard deviations in 2009-2010 & 108 & 121 & 136 & 145 & 153 & 159 & 195 & 239 \\
\hline B2. Primary balance is at historical average minus one standard deviations in 2009-2010 & 108 & 114 & 118 & 121 & 124 & 125 & 134 & 128 \\
\hline B3. Combination of B1-B2 using one half standard deviation shocks & 108 & 111 & 113 & 115 & 117 & 117 & 123 & 112 \\
\hline B4. One-time 30 percent real depreciation in 2009 & 108 & 146 & 148 & 148 & 147 & 145 & 146 & 135 \\
\hline B5. 10 percent of GDP increase in other debt-creating flows in 2009 & 108 & 157 & 163 & 165 & 167 & 167 & 172 & 161 \\
\hline
\end{tabular}

Debt Service-to-Revenue Ratio 2/

Baseline

$\begin{array}{rrrrrrrr}8 & 8 & 8 & 7 & 7 & 8 & 12 & 22 \\ 8 & 8 & 7 & 6 & 7 & 7 & 10 & 18 \\ & & & & & & & \\ & & & & & & & \\ 8 & 8 & 8 & 7 & 8 & 9 & 14 & 21 \\ 8 & 8 & 7 & 6 & 6 & 7 & 8 & 8 \\ 8 & 8 & 7 & 5 & 5 & 5 & 6 & 5 \\ 8 & 8 & 8 & 7 & 7 & 8 & 9 & 10 \\ 8 & 8 & 11 & 11 & 11 & 13 & 13 & 12\end{array}$

\section{A. Alternative scenarios}

Primary balance is unchanged from 2008 Permanently lower GDP growth $1 /$

\section{B. Bound tests}

B1. Real GDP growth is at historical average minus one standard deviations in 2009-2010

B2. Primary balance is at historical average minus one standard deviations in 2009-2010

B3. Combination of B1-B2 using one half standard deviation shocks

B4. One-time 30 percent real depreciation in 2009

B5. 10 percent of GDP increase in other debt-creating flows in 2009

Sources: Country authorities; and Fund staff estimates and projections.

1/ Assumes that real GDP growth is at baseline minus one standard deviation divided by the square root of 20 (i.e., the length of the projection period).

2/ Revenues are defined inclusive of grants. 
INTERNATIONAL MONETARY FUND

SENEGAL

Staff Report for the 2008 Article IV Consultation, First Review Under the Policy Support Instrument, and Request for Waiver of Assessment Criterion and Modification of Assessment Criteria-Informational Annex

Prepared by the African Department

(In collaboration with other departments)

Approved by Sharmini Coorey and Adnan Mazarei

May 30, 2008

- $\quad$ Relations with the Fund. Describes financial and technical assistance by the IMF and provides information on the safeguards assessment and exchange system. Outstanding purchases and loans amounted to SDR 17.33 million (10.7 percent of quota) at end-March 2008.

- Relations with the World Bank. Describes Bank and Fund work program.

- $\quad$ Article VIII Status. Senegal accepted the obligations of Article VIII of the Fund's Articles as of June 1, 1996 and maintains an exchange system free of restrictions on the making of payments and transfers for current international transactions.

- Statistical Issues. Assesses the quality of statistical data. Although the economic database is comprehensive and generally adequate for surveillance, there are weaknesses in data on national accounts, production, international trade, and social indicators. 


\section{Senegal: Relations with the Fund}

(As of April 30, 2008)

I. Membership Status: Joined: August 31, 1962; Article VIII as of June 1, 1996.

II. General Resources Account:

Quota

Fund holdings of currency

Reserve Position

III. SDR Department:

Net cumulative allocation

Holdings

IV. Outstanding Purchases and Loans:

PRGF Arrangements
SDR Million

161.80

160.16

1.66

SDR Million

24.46

0.56

SDR Million

17.33
Percent of Quota

100.00

98.98

1.02

Percent of Allocation

100.00

2.31

Percent of Quota

10.71

\section{Latest Financial Arrangements:}

\begin{tabular}{|c|c|c|c|c|}
\hline Type & $\begin{array}{c}\text { Date of } \\
\text { Arrangement } \\
\end{array}$ & $\begin{array}{l}\text { Expiration } \\
\text { Date }\end{array}$ & $\begin{array}{l}\text { Amount Approved } \\
\text { (SDR Million) }\end{array}$ & $\begin{array}{l}\text { Amount Drawn } \\
\text { (SDR Million) }\end{array}$ \\
\hline$\overline{\mathrm{PRGF}}$ & $\overline{\text { Apr 28, } 2003}$ & Apr $\overline{27,2006}$ & 24.27 & 24.27 \\
\hline PRGF & Apr 20, 1998 & Apr 19, 2002 & 107.01 & 96.47 \\
\hline PRGF & Aug 29, 1994 & Jan 12,1998 & 130.79 & 130.79 \\
\hline
\end{tabular}

\section{Projected Payments to Fund:}

(SDR Million; based on existing use of resources and present holdings of SDRs):

Principal

Charges/Interest

Total
Forthcoming

\begin{tabular}{|c|c|c|c|c|}
\hline 2008 & 2009 & 2010 & 2011 & 2012 \\
\hline & & 0.35 & 2.08 & 3.47 \\
\hline$\underline{0.58}$ & $\underline{0.74}$ & $\underline{0.74}$ & $\underline{0.74}$ & 0.72 \\
\hline 0.58 & 0.74 & 1.09 & 2.82 & 4.19 \\
\hline
\end{tabular}




\section{Implementation of HIPC Initiative: ${ }^{1}$}

Enhanced

I. Commitment of HIPC assistance Framework

Decision point date

June 2000

Assistance committed

by all creditors (US\$ million)

488.30

Of which: IMF assistance (US\$ million)

(SDR equivalent in millions)

Completion point date

April 2004

II. Disbursement of IMF assistance (SDR million)

Assistance disbursed to the member

Interim assistance

Completion point balance

Additional disbursement of interest income ${ }^{2}$

Total disbursements

\section{Implementation of MDRI Assistance:}

I. Total debt relief (SDR million) ${ }^{3}$

100.32

Of which: MDRI

94.76

HIPC

II. Debt relief by facility (SDR million)

\begin{tabular}{rrrr} 
& \multicolumn{3}{c}{ Eligible Debt } \\
\cline { 2 - 3 }$\frac{\text { Delivery }}{\frac{\text { Date }}{2006}}$ & $\underline{\text { GRA }}$ & $\underline{\text { PRGF }}$ & $\underline{\text { Total }}$ \\
January & N/A & 100.32 & 100.32
\end{tabular}

\footnotetext{
${ }^{1}$ Assistance committed under the original framework is expressed in net present value (NPV) terms at the completion point, and assistance committed under the enhanced framework is expressed in NPV terms at the decision point. Hence, these two amounts cannot be added.

${ }^{2}$ Under the enhanced framework, an additional disbursement is made at the completion point corresponding to interest income earned on the amount committed at the decision point but not disbursed during the interim period.

${ }^{3}$ The Multilateral Debt Relief Initiative (MDRI) provides 100 percent debt relief to eligible member countries that are qualified for the assistance. The debt relief covers the full stock of debt owed to the Fund as of end2004 which remains outstanding at the time the member qualifies for such debt relief. The MDRI is financed by
} 


\section{Safeguards Assessments:}

The Central Bank of West African States (BCEAO) is the common central bank of the countries of the West African Economic and Monetary Union, which includes Senegal. The most recent safeguards assessment of the BCEAO was completed on November 4, 2005. The assessment indicated progress has been made in strengthening the bank's safeguards framework since the 2002 assessment and identified some areas where further steps would help solidify it.

The BCEAO now publishes a full set of audited financial statements and improvements have been made to move financial reporting closer to International Financial Reporting Standards (IFRS). Furthermore, an internal audit charter has been put in place, mechanisms for improving risk management have been established, and follow-up on internal and external audit recommendations has been strengthened.

The results of continuous safeguards monitoring indicate that while certain vulnerabilities remain in internal control systems and legal structure, there has been some progress in other areas, including through: (i) improving the external audit process by adopting a multi-year audit program; (ii) establishing an audit committee; (iii) expanding disclosures on financial positions of WAEMU countries with the Fund in the notes to the annual financial statements; and (iv) further strengthening of the effectiveness of the internal audit function.

\section{Exchange System:}

Senegal is a member of the West African Economic and Monetary Union (WAEMU). The exchange system, common to all members of the union, is free of restrictions on the making of payments and transfers for current international transactions. The union's common currency, the CFA franc, had been pegged to the French franc at the rate of CFAF $1=\mathrm{F} 0.02$. Effective January 12, 1994, the CFA franc was devalued and the new parity set at CFAF $1=$ F 0.01. Effective December 31, 1998, the parity was switched to the euro at a rate of CFAF $655.96=€ 1$.

The authorities confirmed that Senegal had not imposed measures that could give rise to exchange restrictions subject to Fund jurisdiction. They will inform the Fund if any such measure is introduced.

Aspects of the exchange system are also discussed in the recent report on economic developments and regional policy issues of the WAEMU. 


\section{Article IV Consultations:}

With the approval of Senegal's PSI, the country is on a 24-month Article IV consultation cycle following the completion of this year's Article IV consultation. The 2006 Article IV consultation was completed by the Executive Board on January 29, 2007 (IMF Country Report No. 7/335). In concluding the Article IV consultation, Executive Directors stressed that renewed efforts at macroeconomic stabilization and deepening of structural reforms would be critical to improve the economy's resistance to shocks, address problems in budgetary discipline and fiscal transparency, and move toward the Millennium Development Goals. Directors welcomed the authorities' intention to lower fiscal deficits over the medium term in order to contain the external current account deficit and prevent debt distress and arrears, and they urged prompt elimination of domestic payment arrears. They called for early efforts to improve policy credibility and fiscal governance and transparency, stressing that such improvements would be crucial for ensuring continued international support to Senegal. Regarding the role of the private sector, Directors urged speedy implementation of the authorities' action plan for improving the business environment and reducing the cost of doing business, which would be crucial for enhancing growth prospects. Directors also observed that the financial sector could make a greater contribution to the economy through improved access to credit and enhanced soundness.

\section{Financial Sector Assessment Program (FSAP) and Report on the Observance of Standards and Codes (ROSC) Participation:}

A joint team of the World Bank and the International Monetary Fund conducted a mission under the FSAP program in November 2000 and January 2001. The Financial System Stability Assessment (FSSA) was issued in August 2001 (IMF Country Report No. 01/189). An FSAP update was undertaken in June 2004, focusing on development issues (in particular nationwide supply of basic financial services and access of SMEs to credit), in line with the priorities defined in the PRSP (IMF Country Report No. 05/126). A regional FSAP for the WAEMU was undertaken in the second half of 2007.

A ROSC on the data module, based on a September 2001 mission, was published on December 2, 2002. An FAD mission conducted a ROSC on the fiscal transparency module in January 2005.

XIII. Technical Assistance:

A. AFRITAC West

\begin{tabular}{lll}
\hline \multicolumn{2}{c}{ Area } & \multicolumn{1}{c}{ Focus } \\
\hline 2003 & $\begin{array}{l}\text { Debt management and financial } \\
\text { markets } \\
\text { Microfinance }\end{array}$ & $\begin{array}{l}\text { Upgrading of information systems; techniques of external } \\
\text { debt management }\end{array}$ \\
2004 & $\begin{array}{l}\text { Initiate work with BCEAO and donors } \\
\text { Public expenditure management } \\
\text { Debt management and financial } \\
\text { markets }\end{array}$ & $\begin{array}{l}\text { Workshop } \\
\text { Evaluation of software for improving debt management; } \\
\text { workshop on AFL/CFT }\end{array}$
\end{tabular}




\begin{tabular}{lll}
\hline \multicolumn{1}{c}{ Area } & \multicolumn{1}{c}{ Focus } \\
\hline \multirow{2}{*}{$\begin{array}{l}\text { Public expenditure management } \\
\text { Debt management and financial } \\
\text { markets }\end{array}$} & $\begin{array}{l}\text { Decentralization; evaluation of TA needs } \\
\text { Assess need for capacity improvement }\end{array}$ \\
& Macroeconomic statistics & $\begin{array}{l}\text { Make fiscal data conform to WAEMU and other } \\
\text { international norms }\end{array}$ \\
& Microfinance & Inspection and control; workshop on good governance; \\
& & training of government supervisory personnel \\
& & \\
Customs administration & Software risks \\
Fiscal administration & Reforms and TA needs \\
Macroeconomic statistics & Evaluate implementation of prior TA and future needs \\
Real sector statistics & Work program for improvement and statistical action plan \\
Microfinance & Supervision \\
Customs administration & Risk analysis and control \\
Fiscal administration & Modernization \\
Debt management and financial & Assess TA needs; regional workshop on external debt \\
markets & statistics \\
Macroeconomic statistics & Public finance statistics \\
Real sector statistics & Institutional sectors and quarterly national accounts; \\
& regional workshop on government accounts \\
Microfinance & Supervision \\
Debt management and financial & DSA workshop \\
markets & Institutional sector accounts \\
Real sector statistics & Supervision and organization \\
Microfinance & \\
& & \\
& &
\end{tabular}

\section{B. Headquarters}

$\begin{array}{llll}\text { Department } & \text { Date } & \text { Form } & \text { Purpose }\end{array}$

$\begin{array}{clll}\text { Fiscal Affairs } & \text { September 2001 } & \text { Staff/consultant } & \begin{array}{l}\text { Assessment of capacity to track poverty- } \\ \text { reducing expenditures }\end{array} \\ & \text { February 2004 } & \text { Staff } & \text { Fiscal reporting } \\ \text { November 2004 } & \text { Staff } & \text { PSIA-Poverty and social impact analysis } \\ \text { January 2005 } & \text { Staff } & \text { ROSC } \\ \text { February 2006 } & \text { Staff } & \text { Tax administration } \\ \text { January 2008 } & \text { Staff } & \text { Public-Private Partnerships } \\ \text { February 2008 } & \text { Staff } & \text { Poverty and social impact analysis }\end{array}$




\begin{tabular}{|c|c|c|c|}
\hline Department & Date & Form & Purpose \\
\hline $\begin{array}{l}\text { Monetary and } \\
\text { Capital } \\
\text { Markets }\end{array}$ & September 2006 & Staff & Bank supervision and regulation \\
\hline \multirow[t]{8}{*}{ Statistics } & September 2001 & Staff & ROSC assessment of data \\
\hline & July 2002 & AFRISTAT & $\begin{array}{l}\text { Real sector statistics assessment. Mission } \\
\text { under GDDS West Africa project }\end{array}$ \\
\hline & August 2002 & AFRISTAT & $\begin{array}{l}\text { National accounts assistance under GDDS } \\
\text { West Africa project. }\end{array}$ \\
\hline & August 2002 & $\begin{array}{l}\text { Regional } \\
\text { advisor }\end{array}$ & $\begin{array}{l}\text { Continued assistance with fiscal sector data } \\
\text { under GDDS West Africa project. }\end{array}$ \\
\hline & December 2002 & AFRISTAT & $\begin{array}{l}\text { Continued assistance with national } \\
\text { accounts and prices statistics under GDDS } \\
\text { West Africa project }\end{array}$ \\
\hline & February 2003 & $\begin{array}{l}\text { Regional } \\
\text { advisor }\end{array}$ & $\begin{array}{l}\text { Continued assistance with fiscal sector data } \\
\text { under GDDS West Africa project. }\end{array}$ \\
\hline & March 2006 & Staff & Real sector statistics \\
\hline & March 2006 & Staff & Government finance statistics \\
\hline
\end{tabular}

\section{Resident Representative}

Stationed in Dakar since July 24, 1984. The position has been held by Mr. Alex SeguraUbiergo since September 22, 2006.

\section{Anti Money Laundering / Combating the Financing of Terrorism}

The onsite visit for Senegal's AML/CFT evaluation took place in July/August 2007 in the context of ECOWAS Inter-Governmental Action Group Against Money Laundering (GIABA). The report was adopted in early May 2008 by the GIABA Plenary held in Accra, Ghana. The report highlights several areas of weaknesses in the AML/CFT system, confirmed by the score of 12 Non-Compliant and 17 Partially Compliant ratings out of the 40+9 FAF AML/CFT recommendations. Table 2 annexed to the Report contains recommendations of the areas which the authorities should address in order to strengthen the AML/CFT system. Following the AML/CFT assessment to be carried out in July/August 2008, the authorities should address the shortcomings identified in the report in order to strengthen the Senegal AML/CFT framework. 
XVI. Fourth Amendment of the Articles of Agreement and the Eleventh Quota Review

The authorities have indicated their agreement with the Fourth Amendment of the Articles of Agreement. The increase in Senegal's quota under the Eleventh General Review of Quotas was completed on February 11, 1999. 


\section{Senegal-Work Program of World Bank and International Monetary Fund, March 2008-June 2009}

\begin{tabular}{|c|c|c|c|}
\hline Title & Products & $\begin{array}{c}\text { Provisional timing of } \\
\text { missions }\end{array}$ & Expected delivery date \\
\hline \multicolumn{4}{|c|}{ A. Mutual information on relevant work programs } \\
\hline World Bank & $\begin{array}{l}\text { Energy Development Policy } \\
\text { Lending } \\
\text { Poverty Assessment } \\
\text { Dakar-Diamniadio toll road } \\
\text { Poverty Reduction Support } \\
\text { Credit IV } \\
\text { Country Assistance Strategy } \\
\text { Progress Report } \\
\text { Public Expenditure Review }\end{array}$ & $\begin{array}{l}\text { April 2008, December } \\
2008 \\
\text { Continuous } \\
\text { April, September } 2008 \\
\text { September-October } \\
2008 \\
\text { February-March } 2009 \\
\text { Continuous }\end{array}$ & $\begin{array}{l}\text { June } 2008 \text { (Board) and } \\
\text { March } 2009 \\
\text { June } 2008 \\
\text { December } 2008 \text { (Board) } \\
\text { December } 2008 \text { (Board) } \\
\text { June } 2009 \\
\text { June } 2009\end{array}$ \\
\hline $\begin{array}{l}\text { International } \\
\text { Monetary Fund }\end{array}$ & $\begin{array}{l}\text { Article IV and First Review } \\
\text { of PSI } \\
\text { Second Review of PSI } \\
\text { Third Review of PSI }\end{array}$ & $\begin{array}{l}\text { March 26-April 9, } 2008 \\
\text { October/November } \\
2008 \\
\text { March/April } 2009\end{array}$ & $\begin{array}{l}\text { June } 2008 \text { (Board) } \\
\text { December } 2008 \text { (Board) } \\
\text { June } 2009 \text { (Board) }\end{array}$ \\
\hline \multicolumn{4}{|c|}{ B. Requests for work program inputs } \\
\hline $\begin{array}{l}\text { Fund request to } \\
\text { Bank (with } \\
\text { summary } \\
\text { justification) }\end{array}$ & $\cdots$ & $\cdots$ & $\cdots$ \\
\hline $\begin{array}{l}\text { Bank request to } \\
\text { Fund (with } \\
\text { summary } \\
\text { justification) }\end{array}$ & $\cdots$ & $\cdots$ & $\cdots$ \\
\hline \multicolumn{4}{|c|}{ C. Agreement on joint products and missions } \\
\hline $\begin{array}{l}\text { Joint products } \\
\text { in next } 12 \\
\text { months }\end{array}$ & $\begin{array}{l}\text { DSA } \\
\text { JSAN }\end{array}$ & $\begin{array}{l}\text { April } 2008 \\
\text { October/November } \\
2008\end{array}$ & $\begin{array}{l}\text { May } 2008 \\
\text { December } 2008\end{array}$ \\
\hline
\end{tabular}




\section{Senegal: Statistical Issues}

1. Overall, the macroeconomic database is comprehensive and adequate for surveillance and program monitoring. However, there are weaknesses in data on national accounts, production, international trade, and social indicators. The authorities are strongly committed to improving the quality and availability of economic, financial and social indicators, partially relying on technical assistance from the Fund and other international organizations. A Report on the Observance of Standards and Codes - Data Module, a Detailed Assessment Using the Data Quality Assessment Framework (DQAF), and a Response by the Authorities were published on the IMF website on December 2, 2002.

2. The country has begun the process of regional harmonization of statistical methodologies within the framework of the West African Economic and Monetary Union (WAEMU). It participates in the General Data Dissemination System (GDDS), and its metadata were posted on the Fund's Dissemination Standards Bulletin Board on September 10, 2001. The metadata are due for updating, including on priority areas for data improvement. In May 2006, a STA mission evaluated dissemination practices against Special Data Dissemination Standard (SDDS) requirements for coverage, periodicity and timeliness and helped the authorities develop an action plan to fill identified gaps.

\section{Real sector statistics}

3. The compilation of the national accounts generally follows the System of National Accounts, 1993. Despite staff's professionalism, the lack of adequate financial resources has constrained efforts to collect and process data. Data sources are deficient in some areas, particularly the informal sector. Owing to financial constraints, surveys of business and households are not conducted regularly and annual input-output tables and institutional sector accounts are not compiled. However, efforts are being made to improve data collection procedures, strengthen the coordination among statistical agencies, and reduce delays in data dissemination.

4. A regional advisor in real sector statistics covering the West AFRITAC countries, including Senegal, was posted for one year beginning December 2005, with a first assessment visit in March 2006 covering real sector statistics. Progress reported by the advisor includes: i) completion of national accounts for 1980-2004 with 1999 as the base year; ii) dissemination of the 1980-2003 series in hard copy and on the internet; iii) production of accounts by institutional sector; and iv) production of national accounts according to schedule. The authorities plan to start production of quarterly national accounts in view of the country's intention to subscribe to the SDDS. The West AFRITAC mission of March-April 2007 assisted with training to support compilation of the quarterly accounts. According to the work program, the first series of quarterly national accounts should be produced by the end of 2008 .

\section{Public finance statistics}

5. Government finance statistics are compiled by the Ministry of Economy and Finance from customs, tax, and treasury directorate sources. Data last reported to STA for electronic redissemination and publication in the 2007 Government Finance Statistics Yearbook were 
for fiscal year 2001. Higher frequency data are not updated for redissemination in IFS, but the ministry compiles and disseminates quarterly government financial operations tables (TOFE) in their own publications. However, the authorities do not have a good handle on domestic arrears data and other payment delays because of weaknesses in the treasury computerization system.

6. An AFR team worked with the authorities in February 2004 to improve fiscal reporting in the context of the last PRGF-supported program. The team focused on (i) public accounts that are outside of the direct purview of the treasury; (ii) the treatment of correspondents' accounts in the TOFE; and (iii) ensuring consistency between treasury and banking system information concerning government transactions. The proposed changes are now being implemented. They will improve the presentation of government financial operations and are the first step toward bringing the TOFE more in line with the extended WAEMU TOFE. Other steps will include implementing the WAEMU fiscal directives that are being revised.

7. A regional advisor in government finance statistics conducted several technical assistance missions aimed at improving the consistency of fiscal reporting and migrating to the methodologies of the Government Finance Statistics Manual 2001. The regional advisor also supported efforts to resume reporting of annual and higher frequency data for publication in International Financial Statistics (IFS) and electronic dissemination of the GFS Yearbook.

\section{Monetary and financial statistics}

8. Preliminary monetary data are compiled by the national agency of the Central Bank of West African States (BCEAO) and officially released (including to the IMF) by BCEAO headquarters. The authorities are now reporting monetary data to STA on a regular basis, with a reduction in the lag from about six months to about three to four months. There has also been an improvement in the timeliness of reporting interest rate and depository corporation data. An area-wide page for the WAEMU zone was introduced in the January 2003 issue of IFS.

9. In 2005, the BCEAO made substantial revisions to the estimates of banknotes in circulation in member states resulting from cross-border banknote movement. These revisions were due to changes in the method to estimate currency in circulation in the WAEMU countries. The revised method, based on updated sorting coefficients ("coefficients de tri”), has been applied retroactively from December 2003.

10. In August 2006, as part of the authorities' efforts to implement the statistical methodology recommended in the Monetary and Financial Statistics Manual, the BCEAO reported to STA test monetary data for June 2006 for all member countries using Standardized Report Forms (1SR-central bank, 2SR-other depository corporations, and 5SRmonetary aggregates). In response to STA's comments, the BCEAO has recently provided a revised $1 \mathrm{SR}$ and indicated that $2 \mathrm{SR}$ is being revised. 


\section{External sector statistics}

11. Balance of payments statistics are compiled by the Senegalese national agency of the BCEAO. With STA support over the past few years, several steps have been taken to address certain shortcomings, including: (i) implementation of the Balance of Payments Manual, fifth edition; (ii) modification and simplification of related surveys for companies and banks;

(iii) improvement in the computerization of procedures; and (iv) significant strengthening of staff training. Nevertheless, further steps could be taken to enhance the quality and coverage of the balance of payments statistics.

12. Although definitive balance of payments statistics can now be provided with a delay of less than one year, there are significant delays in reporting the data to STA. At this time, balance of payment statistics up to the year 2004 and international investment position data up to 2005 have been communicated to STA. 


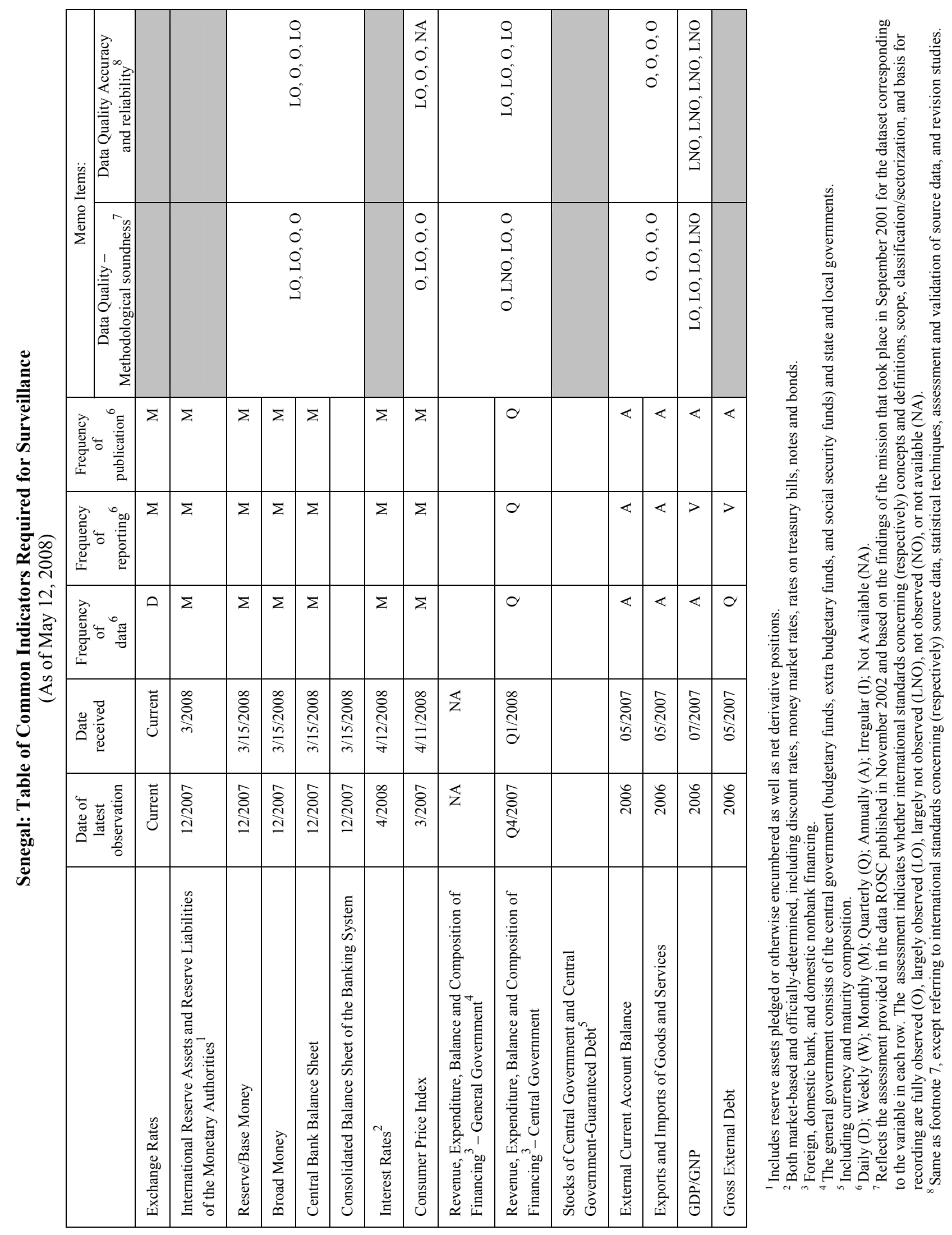




\section{Statement by the IMF Staff Representative \\ June 18, 2008}

1. This statement summarizes developments in Senegal since the issuance of the staff report. Over the past few weeks, the following information has become available, which does not change the thrust of the staff appraisal.

2. Recent indications point to a risk of higher inflation. CPI inflation remained high in the past two months. It slightly exceeded 5 percent year-on-year in April and reached 6 percent in May, with food prices contributing three-fourths of the increase. This could delay the envisaged return to the historical inflation trend by 2009.

3. A continued surge in oil prices could significantly affect Senegal's balance of payments but the impact on the budget would be limited. Using the May 2008 WEO projections, the current account deficit could deteriorate by about $13 / 4$ percent of GDP compared to the staff report (see Table). If the authorities decided not to pass through the higher oil bill to consumers by raising prices of electricity and butane gas, the overall fiscal deficit would rise by about 0.2 percent of GDP. The WEO food price projections for 2008 have remained unchanged.

Senegal: BoP and Budgetary Impact of Higher Oil Prices

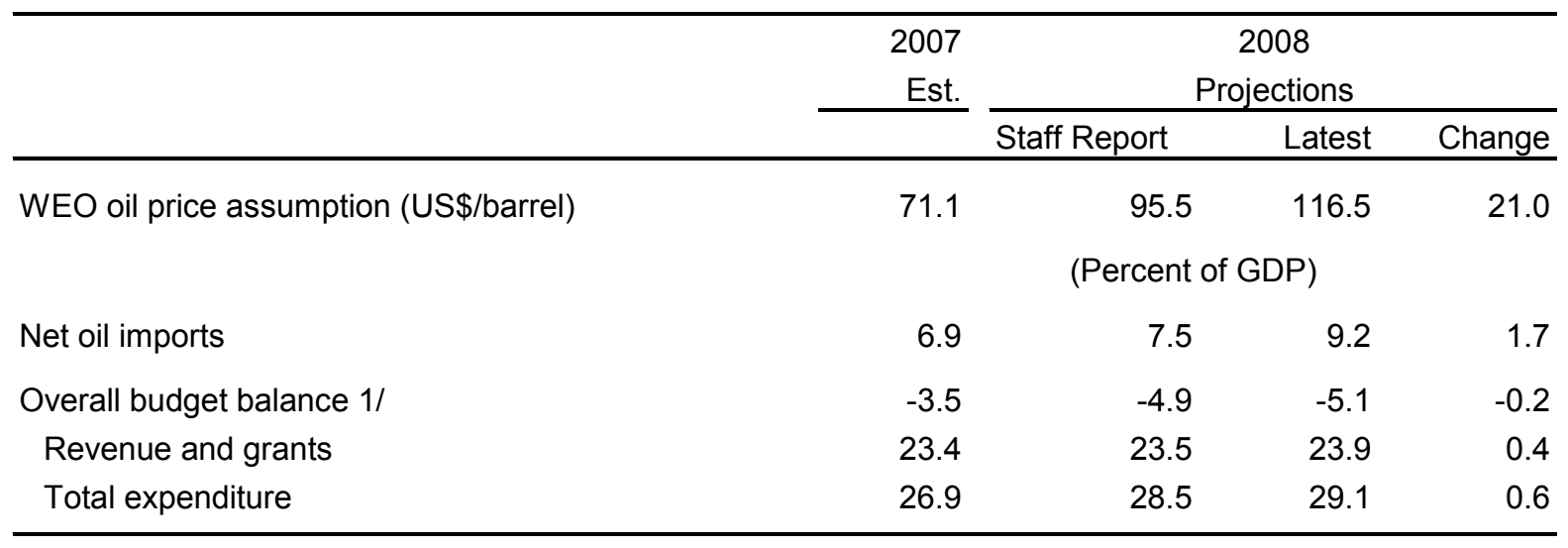

$1 /$ Changes compared to the staff report assume no increase in prices of electricity and butane gas or any other compensatory measures.

4. All structural conditions for the first program review are now in place. With a two-month delay, the authorities completed, at end-May 2008, the submission of the Treasury accounts for 2004 and 2005 to the audit court.

5. The authorities have informed staff that another step has been taken to curtail nonpriority spending in 2008. They have blocked commitment authorizations in the SIGFIP expenditure tracking system, which would enable them to enforce the administrative orders 
of the Prime Minister and Minister of Finance on the reduction in nonpriority spending (paragraph 23 of the staff report).

6. The authorities have launched tenders to issue government securities in the regional financial market. The auctions seek to raise CFAF 40 billion in treasury bills with maturities of up to two years and CFAF 60 billion in ten-year bonds. If successful, they would allow the prompt settlement of the payment delays carried over from 2007 and help remove a drag on the private sector. 


\section{IMF Executive Board Concludes 2008 Article IV Consultation with Senegal}

On June 18, 2008, the Executive Board of the International Monetary Fund (IMF) concluded the Article IV consultation with Senegal. ${ }^{1}$

\section{Background}

Senegal, over the last decade, has achieved macroeconomic stability and recorded economic growth above that in other West African Economic and Monetary Union (WAEMU) countries. Buoyant activity in the services and construction sectors increased GDP growth in 2007 to 43/4 percent, from $2 \frac{1}{4}$ percent in 2006 . However, the agricultural sector experienced a second year of output decline.

Rapidly rising energy and food prices raised inflation in 2007 and put pressure on the fiscal and external accounts. Inflation reached 6 percent, the highest level since the 1994 devaluation. Value Added Tax (VAT) and customs duties on certain food products were suspended in mid-2007, the subsidy on butane gas was gradually raised, and subsidies on petroleum products were introduced in late 2007 . This may have temporarily restrained inflation, but the budgetary costs were substantial, at 11/2 percent of GDP.

\footnotetext{
${ }^{1}$ Under Article IV of the IMF's Articles of Agreement, the IMF holds bilateral discussions with members, usually every year. A staff team visits the country, collects economic and financial information, and discusses with officials the country's economic developments and policies. On return to headquarters, the staff prepares a report, which forms the basis for discussion by the Executive Board. At the conclusion of the discussion, the Managing Director, as Chairman of the Board, summarizes the views of Executive Directors, and this summary is transmitted to the country's authorities.
} 
The overall fiscal deficit was kept at 31/2 percent of GDP in 2007, after 6 percent of GDP a year before. However, expenditure commitments equivalent to 2 percent of GDP have been carried over for settlement in 2008, representing a significant stock of payment delays to the private sector. Fiscal developments were marked by strong revenue collections and increased spending allocations to social sectors.

The external current account deficit in 2007 increased to $101 / 2$ percent of GDP as the cost of importing energy and food rose, but exports plateaued because restructuring of the phosphate producer ICS (Industries Chimiques du Sénégal) was delayed and there were structural obstacles that prevented Senegal from being more competitive. Current account financing benefited from higher foreign direct investment (FDI) and receipts from the sale of a third telecom license, which helped keep external debt indicators broadly unchanged from 2006.

Senegal's macroeconomic policies are being pursued under an economic program supported by the IMF's Policy Support Instrument (PSI), which was approved in November 2007 (see Press Release No. 07/246). The authorities' program has four pillars: (i) containing the fiscal deficit to underpin macroeconomic stability and safeguard debt sustainability; (ii) improving fiscal governance and transparency so as to enhance policy credibility and sustain external assistance; (iii) encouraging private sector activity by improving the business environment and addressing structural impediments to higher economic growth and competitiveness; and (iv) limiting financial sector vulnerabilities and raising the sector's contribution to the economy.

\section{Executive Board Assessment}

Executive Directors commended the Senegalese authorities on the broadly satisfactory implementation of their economic program supported under the PSI. They noted that Senegal's macroeconomic performance had improved in 2007, with a recovery in growth, although rising food and energy prices had increased inflation and put pressure on the fiscal and external accounts.

Directors observed that Senegal's overriding economic challenge was to raise growth and reduce poverty. They encouraged the authorities to maintain prudent macroeconomic policies and persevere in implementing their structural reforms under the Accelerated Growth Strategy. This, together with energy sector reform, continued efforts to attract FDI, and targeted government spending in infrastructure, health, and education, would encourage private sectorled growth, raise external competitiveness, and strengthen and diversify exports.

Directors agreed that Senegal's real exchange rate does not appear to be overvalued, although developments require close monitoring. They considered that Senegal's sluggish export performance over the last decade was largely related to structural impediments in the economy, and encouraged the authorities to improve the business environment to make it more conducive to private sector activity by accelerating governance and structural reforms. 
Directors welcomed the authorities' commitment to fiscal sustainability. They underlined that it was critical to contain the fiscal deficit to preserve debt sustainability, respect the limited financing capacity of the regional financial market, and contain demand pressures, thereby promoting domestic stability in the context of Senegal's monetary union membership. Directors commended the authorities for their continued good revenue performance, which helped support fiscal sustainability. In addition, they welcomed the planned strengthening of tax administration, including the transfer of responsibility for direct tax collections from the Treasury to the Revenue Authority.

Directors supported the authorities' intention to correct the 2007 fiscal slippages, and stressed that it will be crucial to reign in non-priority capital and current spending in 2008 in order to make room for the settlement of expenditure commitments from 2007. Directors urged the careful review and expeditious settlement of payment delays, with a view to rigorously applying the existing budget framework.

Directors recognized the potential of the planned Dakar Integrated Special Economic Zone in generating growth and employment, but emphasized the need to avoid any loss of tax revenues from domestic enterprises moving to the zone and to put in place the necessary safeguards to combat tax fraud and evasion.

Directors noted that international food and energy price increases had placed a considerable burden on the population, and concurred with the authorities that measures should be taken to shield the population's most vulnerable segments from these price increases. Directors saw scope for improving the targeting of the existing measures while minimizing economic distortions and keeping them affordable so that they remained consistent with macroeconomic stability and debt sustainability. For the longer term, they recommended the introduction of a social safety net. In addition, Directors encouraged the authorities to promote the development of the agricultural sector.

Directors welcomed the authorities' commitment to continue public financial management reform and to improve financial sector supervision in the regional context. In particular, given Senegal's emphasis on public investment to support economic growth, they encouraged the authorities to further strengthen their investment planning and evaluation to focus on highreturn projects and raise the productivity of government spending. In this context, Directors agreed that the nonconcessional borrowing that the authorities intend to undertake to help finance the Dakar-Diamniadio toll road is appropriate in light of its projected high return and the lack of other financing sources. In addition, they urged a strong implementation of the new public procurement framework. 
Public Information Notices (PINs) form part of the IMF's efforts to promote transparency of the IMF's views and analysis of economic developments and policies. With the consent of the country (or countries) concerned, PINs are issued after Executive Board discussions of Article IV consultations with member countries, of its surveillance of developments at the regional level, of post-program monitoring, and of ex post assessments of member countries with longer-term program engagements. PINs are also issued after Executive Board discussions of general policy matters, unless otherwise decided by the Executive Board in a particular case. 
Senegal: Selected Economic Indicators

20032004

$2005 \quad 2006 \quad 2007$

Est.

National income and prices (percent change)

GDP at constant prices

Inflation (average)

6.7

5.9

5.6

2.3

4.8

0.0

0.5

1.7

2.1

5.9

External sector

Current account balance (percent of GDP)

$\begin{array}{lllll}-6.1 & -6.1 & -7.8 & -9.4 & -10.4\end{array}$

Exports (in CFA francs, percent change)

$-1.7 \quad 9.2$

4.4

$0.1 \quad-2.9$

Imports (in CFA francs, percent change)

7.1

9.8

15.6

$9.0 \quad 12.7$

Real effective exchange rate (percent change)

2.5

0.1

$-1.3$

$-0.2$

4.6

Money and credit

Credit to the economy (percent change)

14.

4.3

9.2

24.5

4.2

10.7

Government budget (percent of GDP)

Revenue

18.

Grants

Total expenditure and net lending

Overall balance

Central government domestic debt

External public debt

$\begin{array}{rrrrr}18.1 & 18.3 & 19.2 & 19.9 & 20.9 \\ 1.9 & 2.1 & 1.6 & 1.5 & 2.5 \\ 21.6 & 23.3 & 24.1 & 27.5 & 27.2 \\ -1.3 & -3.1 & -3.0 & -5.8 & -3.5 \\ 3.9 & 3.5 & 3.3 & 4.3 & 5.6 \\ 50.8 & 44.0 & 42.4 & 17.8 & 18.1\end{array}$


Press Release No. 08/141

International Monetary Fund

FOR IMMEDIATE RELEASE

Washington, D.C. 20431 USA

June 18, 2008

\section{IMF Executive Board Completes the First Review Under the Policy Support Instrument (PSI) for Senegal}

The Executive Board of the International Monetary Fund (IMF) today completed the first review under a three-year Policy Support Instrument (PSI) for Senegal. The Board also granted a waiver for the nonobservance of the continuous quantitative assessment criterion on the stock of domestic payment arrears by the government, noting that the authorities had taken action quickly to remedy the nonobservance.

The PSI for Senegal was approved on November 2, 2007 (see Press Release No. 07/246) and is aimed at consolidating macroeconomic stability, increasing the country's growth potential, and reducing poverty. The program focuses on maintaining a sound fiscal policy stance and enhancing fiscal governance and transparency. It also includes measures to develop the private sector and increase the financial sector's contribution to growth.

Following the Executive Board's discussion on Senegal, Mr. Murilo Portugal, Deputy Managing Director and Chairman, stated:

"Senegal's economic growth recovered in 2007, but rapidly rising food and energy prices raised inflation and put pressure on the fiscal and external accounts. The main challenges for the Senegalese authorities are to further raise economic growth, maintain macroeconomic stability, and reduce vulnerabilities.

"The removal of structural impediments to economic growth is key to fostering private sector-led growth, raising external competitiveness, and strengthening and diversifying exports. In this context, the Senegalese authorities are encouraged to put in place the structural reforms envisaged under their Accelerated Growth Strategy. In addition, implementation of energy sector reform, continued efforts to attract foreign direct investment, and targeted government spending in infrastructure, health, and education, will be conducive to raising Senegal's growth potential.

“The authorities' emphasis on safeguarding fiscal sustainability underpins the economic program supported under the PSI. The envisaged medium-term fiscal adjustment path will help preserve debt sustainability, respect the limited financing capacity of the regional financial market, and contain demand pressures, thereby promoting domestic stability in the context of Senegal's monetary union membership. Measures to safeguard Senegal's 
traditionally strong revenue performance, including with respect to the planned Dakar Integrated Special Economic Zone, will help shore up fiscal sustainability.

"The authorities have committed to correct the 2007 fiscal slippages, and have decided to rein in non-priority capital and current spending in 2008 in order to allow for the settlement of the 2007 expenditure commitments. Priority should now be given to rapidly completing a careful review of these commitments, settling them expeditiously, and rigorously applying the existing budget framework.

"International food and energy price increases are placing a considerable burden on the population, in particular the most vulnerable segments. It is important to ensure that the policy measures to alleviate this burden are affordable, well targeted, and nondistortionary. Implementation of the new electricity tariff structure would help recover costs and at the same time favor low-income households. In the long run, the implementation of an effective social safety net should be considered.

"Given the tight budgetary constraints, it will be essential to further strengthen investment planning and evaluation and focus on high-return projects to raise the productivity of government investment. In implementing their investment program, the authorities appropriately rely on concessional financial resources so as to preserve debt sustainability," Mr. Portugal said.

The IMF's framework for PSIs is designed for low-income countries that may not need, or want, IMF financial assistance, but still seek IMF advice, monitoring and endorsement of their policies. PSIs are voluntary and demand driven. PSI-supported programs are based on country-owned poverty reduction strategies adopted in a participatory process involving civil society and development partners and articulated in a Poverty Reduction Strategy Paper (PRSP). This is intended to ensure that PSI-supported programs are consistent with a comprehensive framework for macroeconomic, structural and social policies to foster growth and reduce poverty. Members' performance under a PSI is reviewed semi-annually, irrespective of the status of the program (see Public Information Notice No. 05/145). 


\section{Statement by Laurean Rutayisire, Executive Director for Senegal June 18, 2008}

1. We thank staff for the comprehensive reports on Senegal and for the productive policy discussions held with the country's authorities during the mission for the first Policy Support Instrument (PSI) review and the 2008 Article IV consultation. We are appreciative of the useful advice the staff has continued to provide to the authorities in support of their efforts to overcome the policy challenges facing the country and we acknowledge the valuable role played by Management and the Board in this process. Keeping up with their attachment to transparency, the authorities have consented to the Fund publication of their letter of intent and the staff report.

2. As discussed in the staff report and below, the authorities' implementation of the PSI structural conditionality and quantitative conditions has been almost perfect to date. In addition to signaling the authorities' strong ownership of, and their commitment to, the program's objectives and reform agenda, this impressive performance should put to rest doubts previously expressed by a few Directors about the qualification of Senegal for the status of mature stabilizer and good PSI candidate. Notwithstanding the significant progress made in the implementation of their reform agenda, the authorities are aware that key policy challenges remain to be tackled. They are determined to continue their reform efforts and, in this endeavor, they will continue to welcome the Fund's useful advice.

\section{ECONOMIC AND STRUCTURAL PERFormance UNDER THE PSI AND ECONOMIC OUTLOOK}

3. In 2007, a number of developments are noteworthy on the macroeconomic front. Reflecting the dynamism of the Senegalese economy, particularly in the secondary and tertiary sectors, the rate of GDP growth doubled compared to the previous year, reaching almost 5 percent. Higher energy and food prices continued, however, to take a big toll on inflation and the current account deficit which rose to about 6 percent and 10 percent respectively. In spite of these shocks which, from the authorities' standpoint, justified granting additional subsidies and introducing temporary tax exemptions on a limited number of consumption goods, the authorities succeeded in meeting the targeted basic fiscal balance and reducing the overall fiscal deficit. However, given the strong budgetary pressures in the face of several competing priority needs and the inflexibility of the targeted basic fiscal balance, these achievements came at the cost of the timeliness of the issuance of some payment orders and unfulfilled spending commitments even though expenditures in priority sectors were increased.

4. In line with the authorities' strong commitment to sound macroeconomic policies, all quantitative assessment criteria were met, except for the one on domestic payment arrears which was inadvertently missed during the first few weeks of the program period. However, 
in view of the corrective action they have taken, the authorities are hopeful that Directors will support their request for waiver of the assessment criterion.

5. In addition to the prowess they have demonstrated on the macroeconomic front, the authorities have shown a determined implementation of their structural reform agenda. Indeed, the single-worded comments in Table 9 of the staff report convey a clear sense of the impressive implementation of the PSI reform agenda, with virtually all of the dozen of structural conditions set for the PSI review being met. With respect to the sole condition that was partially met, the authorities have renewed their commitment to submit to the audit court the complete 2004 and 2005 Treasury accounts.

6. The authorities remain optimistic about the country's economic outlook. Growth prospects are favorable given the expected continuous dynamism of the construction sector and services. Thanks to the regional central bank's prudent policies, core inflation is expected to be kept low going forward. External current account balance is expected to fluctuate around its current level and to be partly improved by the implementation of the new restructuring plan of the chemical company, Industries Chimiques du Senegal, which is expected to pave the way for full recovery of the company, thereby boosting exports. As many spending commitments made in 2007 are expected to be settled this year, the fiscal deficit is expected to increase before following a downward path in 2009 onwards.

POLICY AND REFORM AGENDA FOR 2008-2009

7. The authorities have thus far made significant strides in advancing the reform and policy agenda they have elaborated in the context of the PSI program, with staff's valuable assistance. Still, they are fully aware that much remains to be done to overcome the significant challenges facing the country, notably coping with rising food and energy prices, sustaining improvement in fiscal governance and transparency, and advancing the remaining reform agenda.

\section{Coping with Food and energy price shocks}

8. Rising food and energy prices has been a key challenge facing the Senegalese authorities both on the policy and social fronts. As in many other countries, this shock has triggered an outburst of consumers' outcry in Senegal. As the authorities attach high priority to mitigating the adverse impact of the shock on social welfare, the initial policy response consisted in a series of actions that included suspension of indirect taxes and customs duties on a few food products as well as energy subsidies, thus contributing to fueling existing pressures on the budget. However, determined not to let these measures come at the expense of macroeconomic stability and fiscal sustainability, the authorities subsequently took vigorous steps to rationalize public spending in nonpriority sectors and address payment delays while safeguarding public expenditures in social sectors. Most notably, the 
administrative orders sent last month by the Prime Minister and the Minister of Economy and Finance to all line ministries were meant to serve these purposes.

9. Going forward, the authorities also intend to elaborate mechanisms for better targeting this assistance to the most vulnerable households. In this process, staff analysis of the policies to protect the poor from rising energy and food prices will be of great interest. They will aim to achieve higher agricultural production and lower production costs in the energy sector which they view as medium-term solutions to these shocks. Several initiatives are already underway in this connection, including infrastructure development and productivity-enhancing measures in both the agricultural and energy sectors and the recapitalization of the electricity company. At the regional level, they will take part to efforts that WAEMU finance ministers recently agreed to undertake in order to cope with increases in food and energy prices.

\section{Sustaining Improvements in Fiscal Governance and Transparency}

10. As we noted during last Board discussions on Senegal, the authorities had started to take steps toward improving fiscal governance and transparency and reducing fiscal risks. Those steps included, inter alia, disclosure of the contracts signed by the government, notably with the project company, AIBD, the construction company, banks, and the International Air Transport Association (IATA); full public ownership of AIBD; publication of the amount of airport tax revenues collected through IATA; enactment of a new procurement code which limits recourse to no-bid contracts in the public sector; and modification of the legal status of the Agency for investment promotion and major public projects, APIX. Since then, other big leaps have been made in the same direction, notably by modifying the legal status of the Agency for investment promotion and major public projects, APIX, containing energy subsidies, and lifting the government's guarantee on ICS debt to local banks.

11. Going forward, the authorities' aspiration for improved fiscal governance and transparency will be served by further steps they plan to take in the coming months. In particular, starting from the end of this month, government contracts awarded each quarter will be put in the public domain and subjected to audits. Butane gas subsidies will be significantly reduced this year and capped at CFAF 32 billion, consistent with the authorities' intent to gradually eliminate them in the medium-term.

12. The authorities are determined to promptly settle any payment delays and extrabudgetary spending that may have occurred. A full account of such delays and spending is expected to be made soon by the financial audit inspectorate of the finance ministry. The authorities will also take a number of further steps aimed at strengthening the budgetary framework, smooth the different phases of budget execution, and improve budget monitoring, including by introducing ceilings on the stock of budgetary float. In view of their large infrastructure program and in line with their previous commitment, the authorities will 
work, in coming months, on elaborating guidelines to strengthen public investment planning and evaluation.

13. Furthermore, the authorities' plan to implement measures aimed at enhancing the already highly performing tax administration bodes well for the prospects of revenue mobilization. These measures include connecting the information systems of the main taxcollecting offices and streamlining of direct tax collection responsibilities between the treasury and the tax department.

\section{Further Advancing the Reform Agenda}

14. The authorities continue to abide by their commitment to ensure that the planned Special Economic Zone is at least revenue neutral and has no adverse impact of the equity of the fiscal system. To that resolve they have finalized a comprehensive study on the fiscal incidence of the Special Economic Zone. The study analyzes many fiscal implications of the project, particularly on the legal, institutional and economic fronts. They also plan to take specific actions in 2009 that will include: identification of enterprises and sectors that will be authorized to operate in the Zone; sanctions to be effected in case of violations of the Zone's laws and regulations; and clear delineation of the roles of the Zone's governing body and the tax and customs Directorates.

15. With regard to the financial sector, the authorities will continue to pursue their previously stated objectives, notably improvement of the soundness of the sector and SMEs' credit access. For the coming months, their reform agenda will thus include, inter alia, implementing the new legal framework for the microfinance sector, continuing to build capacity of the finance ministry's unit in charge of supervising the sector, submitting to Parliament the new regional law against the financing of terrorism, and establishing a program of regular issuance of government securities.

16. The authorities' reform efforts continue to encompass other macrocritical sectors, as well. In particular, work is underway to increase private sector's involvement in the governance of the energy sector. In the case of the electricity company, SENELEC, such work is being conducted with the assistance of the World Bank. Major reforms are also being conducted by the authorities to make the economy fast-growing and competitive. An institutional framework for implementing the authorities' Accelerated Growth Strategy has been adopted and critical reforms to improve the business climate are underway. Partly reflecting the effectiveness of such reforms, the country is attracting increasingly significant FDI and positioning itself as a major investment pole in the region. 


\section{ADDITIONAL REMARKS AND CONCLUSION}

17. The authorities would welcome more flexibility in the program fiscal targets. As noted above, their effort to meet the target for the basic fiscal balance was viewed as one of the causes of the distortions that affected budget execution last year, notably by contributing to delays in the issuance of payment orders and unfulfilled spending commitments. While such a situation may require from the authorities better consideration of budgetary ceilings, it also provides a rationale for ensuring more flexibility in fiscal targets set Senegal's PSI and Fund-supported programs in general. Occasional departures from a tight fiscal stance should be allowed from the authorities' perspective so long as long-term fiscal sustainability is preserved. This would allow programs not only to better accommodate unexpected shocks and critical infrastructure needs, and thus growth objectives, but also not to introduce any distortions in budget execution processes.

18. In a bid to preserve debt sustainability, the Senegalese authorities remain committed to sound debt management and they continue to have a strong preference for contracting and guaranteeing external loans on concessional terms. However, the increasingly limited availability of concessional loans and grants is becoming more and more at odds with their growing needs for such resources with a view to financing their infrastructure development needs. This partly motivates the following requests they have submitted for Fund consideration. First, they add their voice to that of other authorities in our Constituency who have previously made calls for the Fund to revisit the definition of concessionality in its arrangements, ultimately with the aim at lowering possibly the required minimum grant element. Such a move would help countries like Senegal mobilize additional development financing and would naturally continue to require strict monitoring of the impact of new borrowing on debt sustainability, as is already the case.

19. Second, the authorities appreciate the new nonzero program ceiling on the contracting or guaranteeing of new nonconcessional external debt which accommodates one of their high priority projects, the Dakar-Diamniado toll highway. For future reference, they would appreciate it if the Fund would find ways to allow the PSI program to respond more swiftly to a need for upward adjustment in the ceiling on nonconcessional financing when concessional resources and grants are unavailable to finance priority development projects for which associated returns exceed the cost of nonconcessional borrowing. They view a protracted consultation process with staff in the run-up to such an adjustment as counterproductive and at odds with the needs of a dynamic economy.

20. In light of the above, we call on Directors to consider favorably the authorities' requests and to support completion of the first review of the PSI program. 